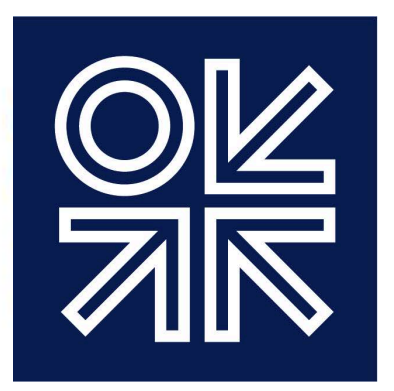

THE OXFORD

INSTITUTE

FOR ENERGY

STUDIES

November 2015

\title{
US Shale Oil Dynamics in a Low Price Environment
}

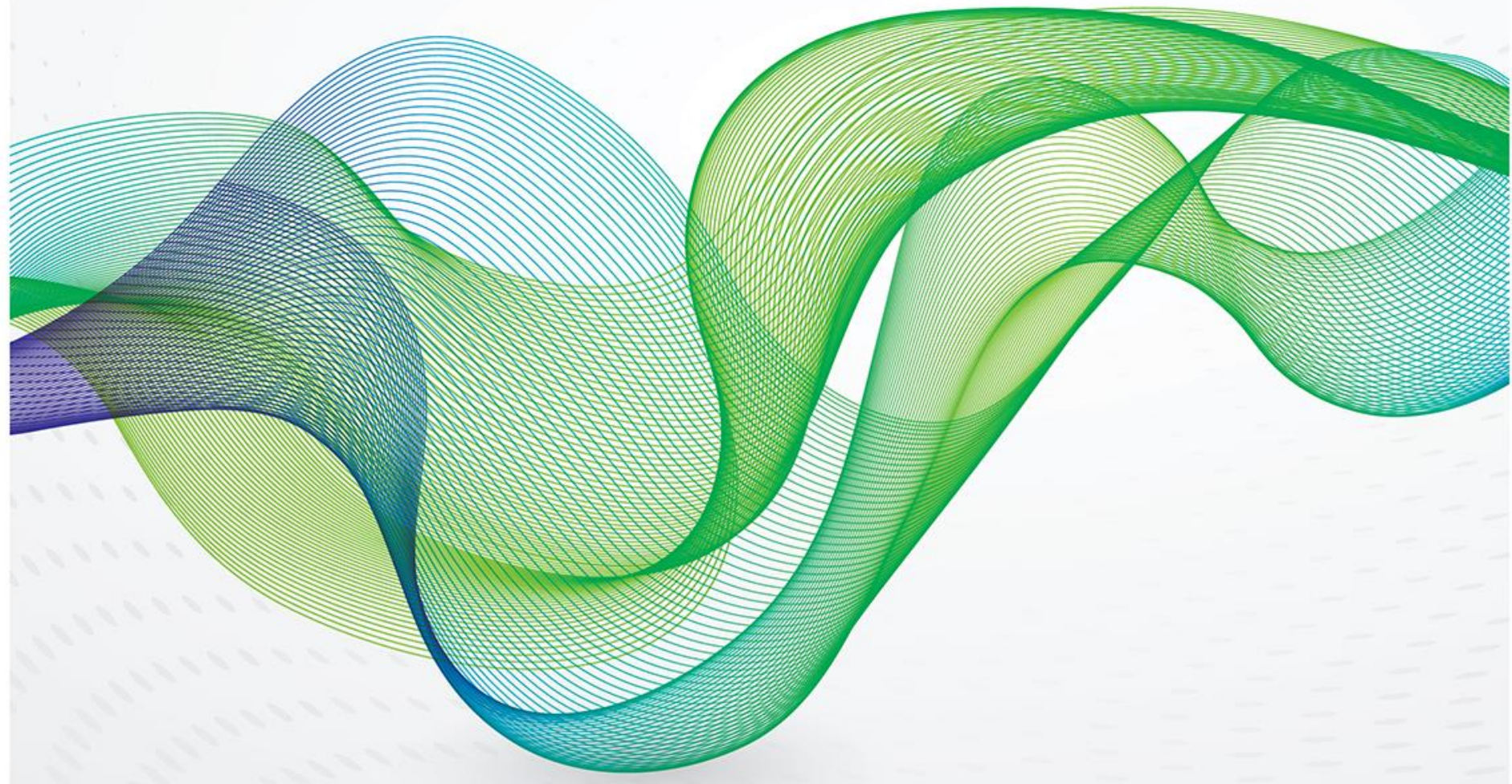



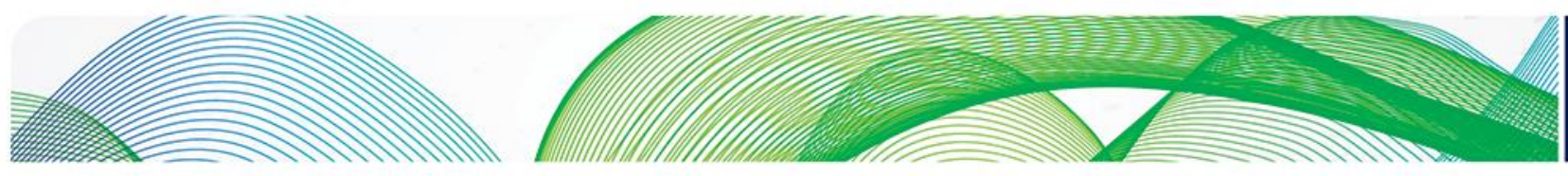

\section{O는}

The contents of this paper are the authors' sole responsibility. They do not necessarily represent the views of the Oxford Institute for Energy Studies or any of its members.

Copyright $\odot 2015$

Oxford Institute for Energy Studies

(Registered Charity, No. 286084)

This publication may be reproduced in part for educational or non-profit purposes without special permission from the copyright holder, provided acknowledgment of the source is made. No use of this publication may be made for resale or for any other commercial purpose whatsoever without prior permission in writing from the Oxford Institute for Energy Studies.

ISBN 978-1-78467-043-6

*Director of Research, Upstream and Midstream, Energy Policy Research Foundation, Inc. (EPRINC), and Visiting Research Fellow, Oxford Institute for Energy Studies 

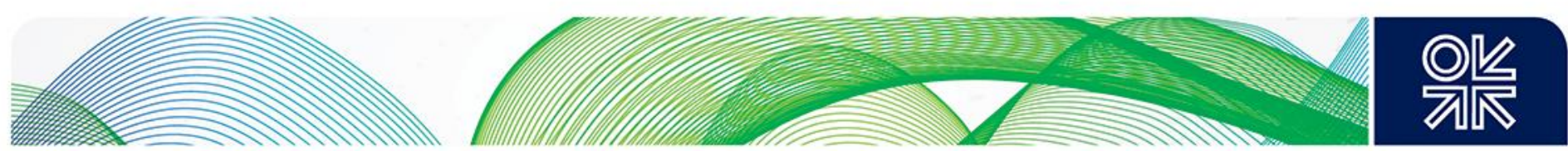

\section{Contents}

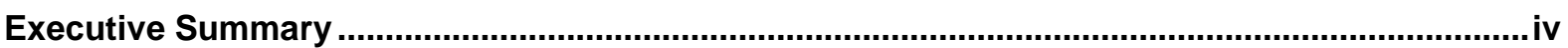

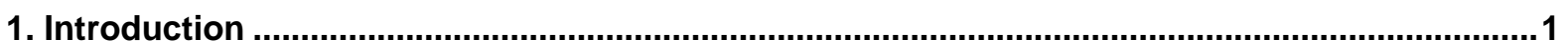

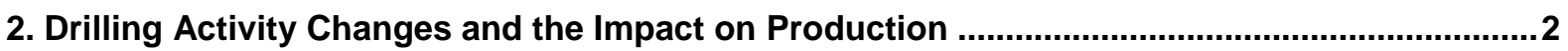

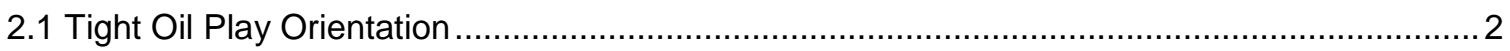

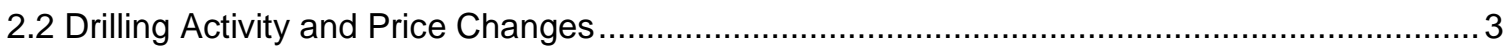

2.3 The Rig Count and West Texas Intermediate ................................................................. 4

2.4 Contributions to Resilient US Oil Production: Drilling Efficiency Gains and Cost Reductions ..5

2.5 Financial Capacity of US Independent Oil Companies Proves Resilient ................................ 6

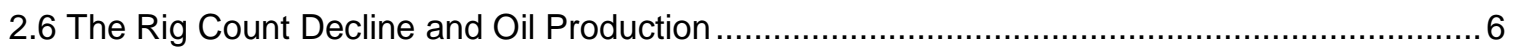

3. Breaking Down the Three Major US Tight Oil Plays: The Williston Basin (the Bakken) ...........9

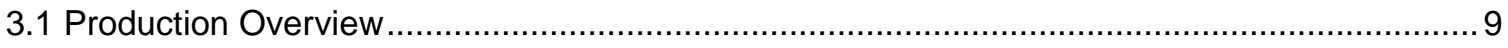

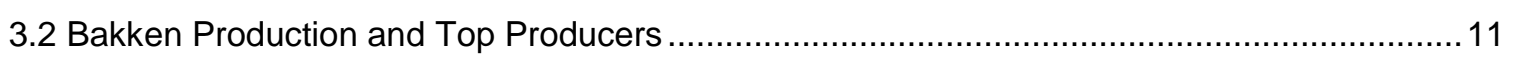

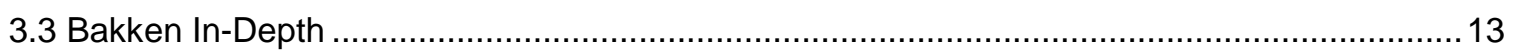

3.4 Recent Activity and Well Performance ……................................................................. 14

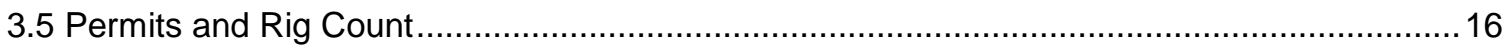

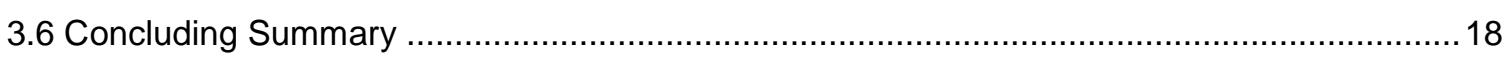

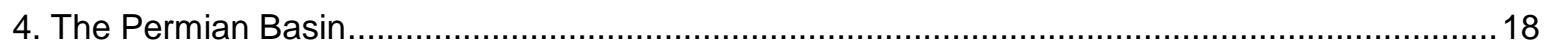

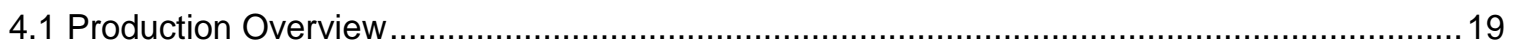

New Mexico and Texas Horizontal and Vertical Production Breakdown ............................21

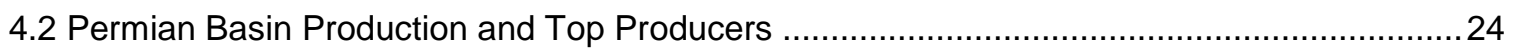

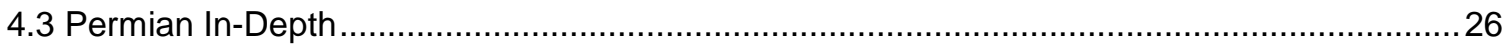

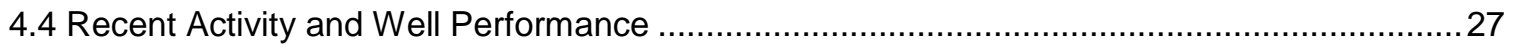

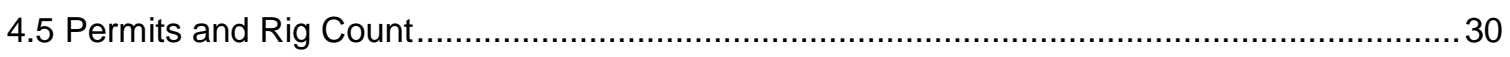

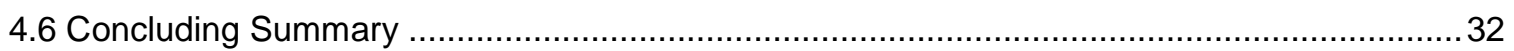

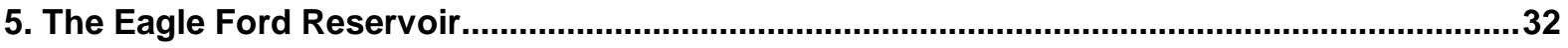

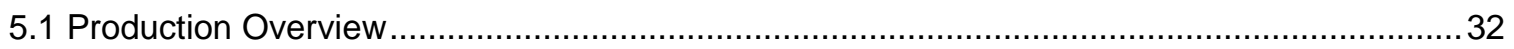

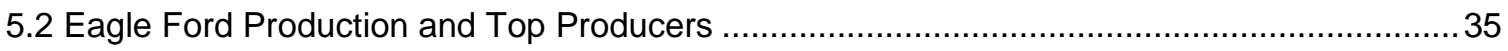

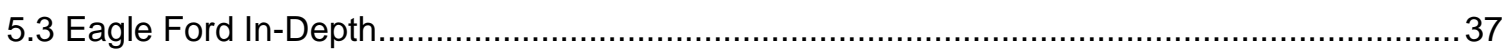

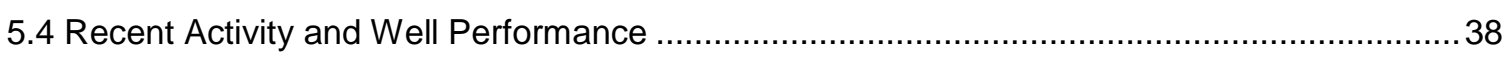

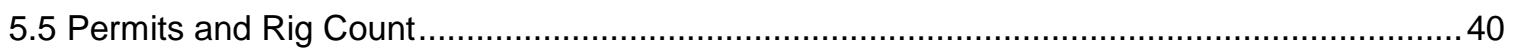

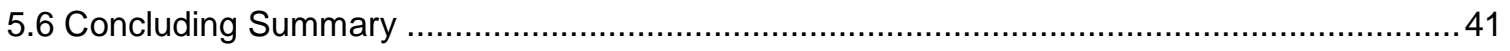

6. Risked Production - Capital Expenditure Cuts and Financial Performance .............................41

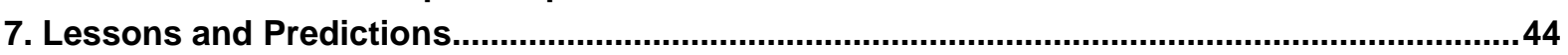



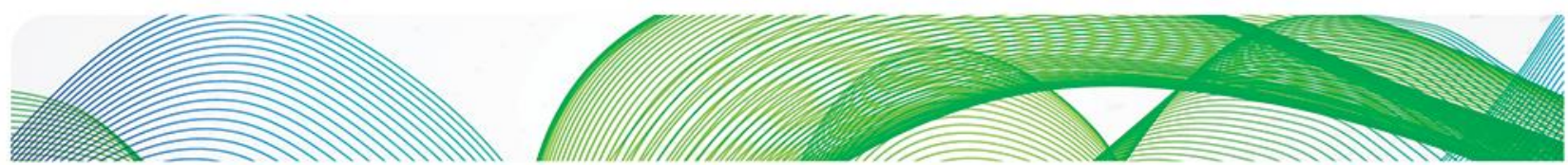
O는

\section{Tables}

Table 1: US Production and Oil Rig Count.

Table 2: North Dakota Oil Production and Rig Count ................................................................................ 11

Table 3: Permian Basin Liquid Production and Rig Count ...........................................................................21

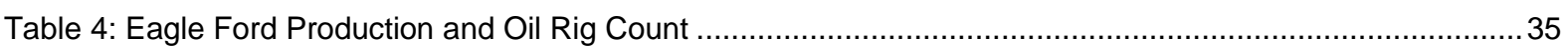

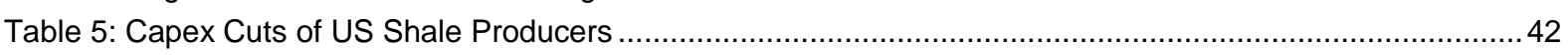

\section{Figures}

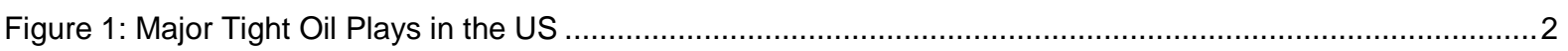

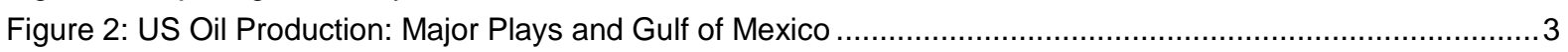

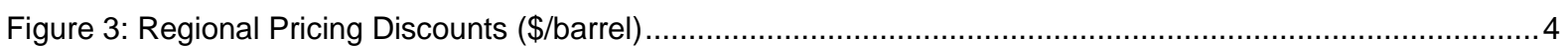

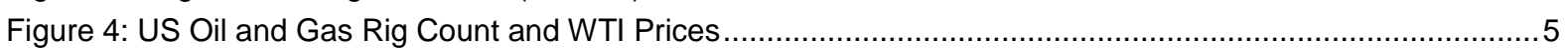

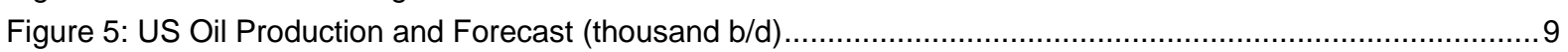

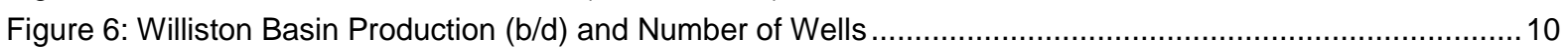

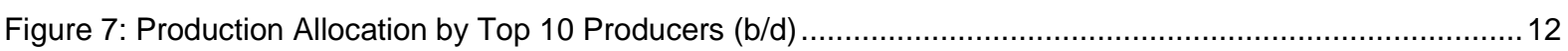

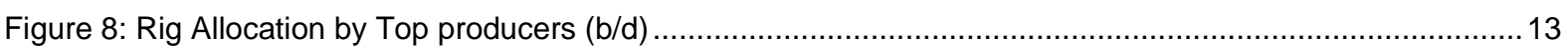

Figure 9: Wells Brought Back into Production Beginning January 2015, Bakken ……...................................15

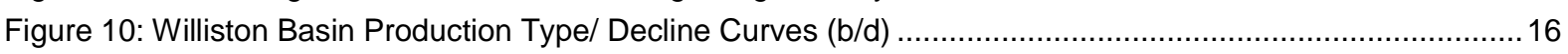

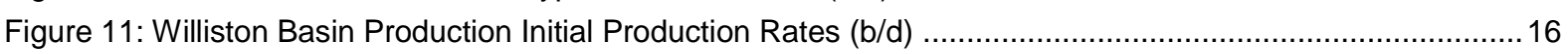

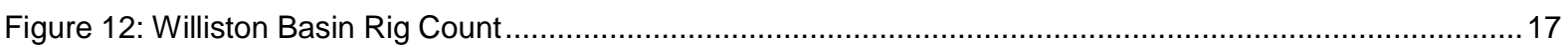

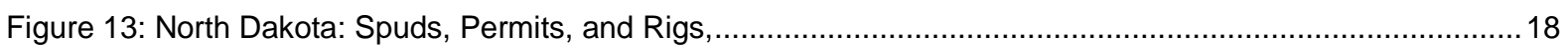

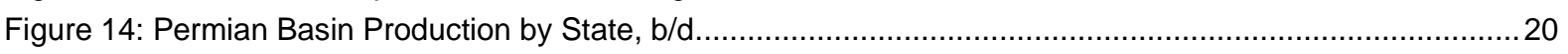

Figure 15: New Mexico: Horizontal-Permian Basin Production and Number of Wells.......................................22

Figure 16: New Mexico: Vertical, Permian Basin Production and Number of Wells ..........................................22

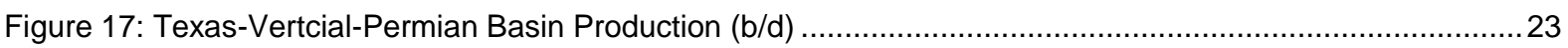

Figure 18: Texas: Horizontal-Permian Basin Production and Number of Wells ..............................................24

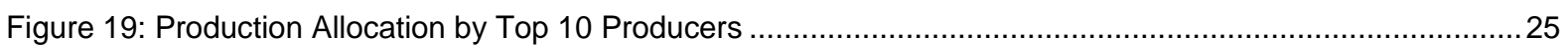

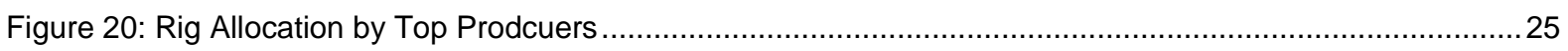

Figure 21: Wells brought online from January 2015 onwards in Permian Basin ...........................................27

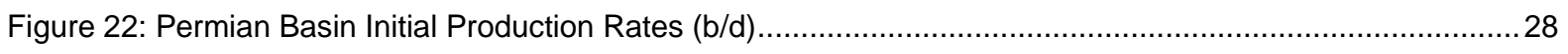

Figure 23: New Mexico: Horizontal Permian Basic Production Type/Decline Curve ………………...................29

Figure 24: Texas: Horizontal Permian Basin Production Type/Decline Curves................................................29

Figure 25: Texas and New Mexico: Vertical Permian Basin Production Type/Decline Curves ............................30

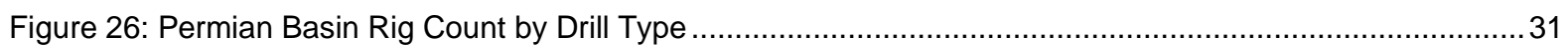

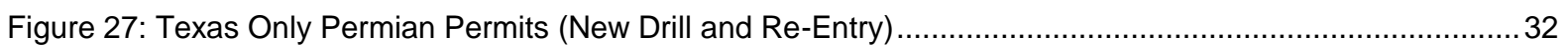

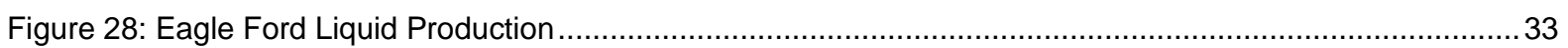

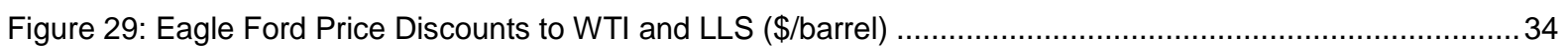

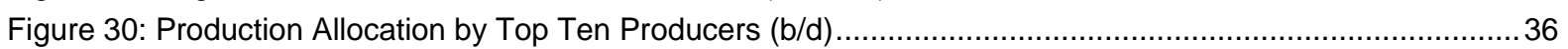

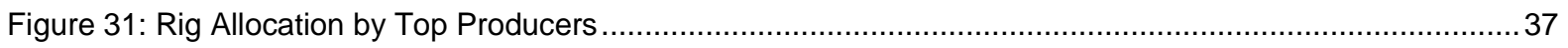

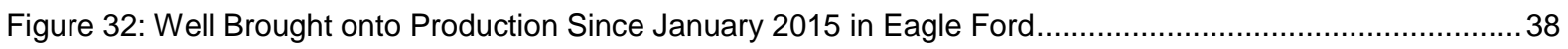

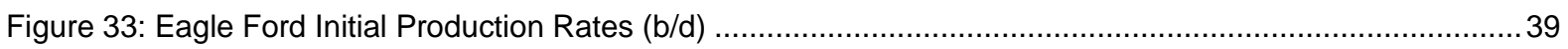

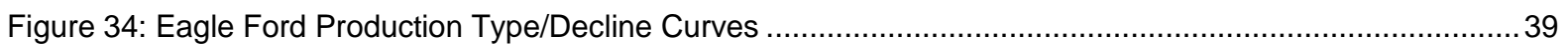

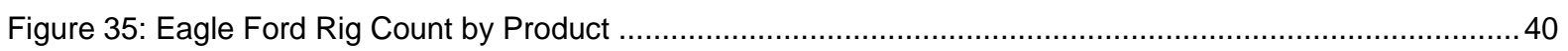

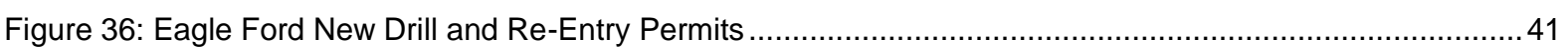

Figure 37: US Onshore Oil Producers' Debt Service as a Share of Operating Cash Flow.....................................43 

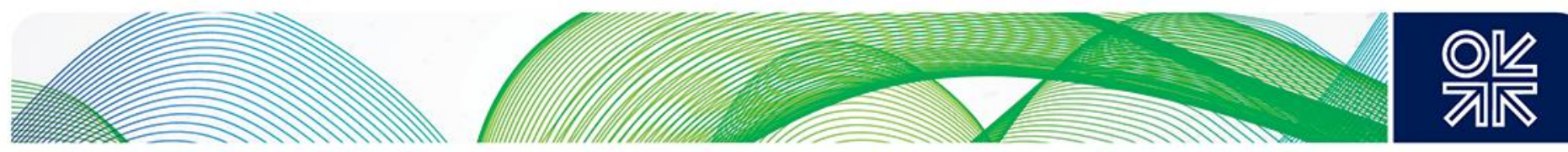

\section{Executive Summary}

- US unconventional oil has proved to be more resilient than originally anticipated, and shale producers have been able to maintain production at relatively high levels through several months of low oil prices. Production has only recently begun to decline. Companies are in fact doing more with less: cutting costs and getting higher initial production per well. Drilling and completion costs have come down considerably as the service sector discounts services to try and retain market share. Efficiency gains have proved stronger than anticipated and are a result of a number of factors, including better equipment, reduced drilling times, better use of horsepower, and an overall acute awareness of the need to cut costs.

- However, after 2015's second-quarter conference calls, oil prices dropped to lows of $\$ 37$ dollars a barrel. They have since recovered to the mid- $\$ 40$ range (at the time of writing), but this movement paints a bleak picture for future production. A further reduction in capital expenditures, shrinking oil rig counts, reduced risk appetite among lenders, and the potential for rising interest rates are all weighing on future production levels in the US. Despite efficiency gains, the number of rigs drilling for oil continue to decline as oil prices falter. This depressed rig count is just now beginning to impact production levels and will further impact production in the coming months.

- Current production data reflects relative stability in the Bakken, but production declines are on the horizon and may perhaps be imminent. The rig count has been reduced by nearly twothirds since January and permit levels are considerably lower than 2014. The number of wells waiting on completion continues to rise month over month. Well performance has continued to impress, but this is a direct result of enhanced completions in core acreage positions. Bakken production is largely controlled by the top 10 producers; this lack of producer diversification will have an impact on future drilling activity levels and future production as many of these companies delegate capital to other assets which require drilling to hold acreage positions.

- The Permian Basin is currently the most resilient oil play in the face of lower oil prices, but this is only relative to its peers - the Bakken and Eagle Ford. Activity levels remain high in comparison, but Texas and New Mexico production is beginning to show the first signs of decline. Many companies in the Permian Basin are still in the early innings of developing their assets, and they have maintained drilling activity levels despite the decline in oil prices because they need to drill in order to hold acreage by production, in addition to adding reserves to the books. However, recent rig additions over the summer have been withdrawn reflecting multiple months of prices below $\$ 50$ per barrel.

- Of the three major unconventional oil plays, the Eagle Ford has shown the most tangible signs of weakness - production has dropped over 150,000 b/d from March 2015. The top 10 Eagle Ford producers contribute the bulk of Eagle Ford liquids production and many of these operators have concentrated assets in the volatile oil and condensate windows. Production has declined month over month and producer optimism is waning. High crude and condensate discounts already pressured Eagle Ford revenues prior to the price decline and are now further exacerbating the strain on revenues.

- Financial worries are beginning to rise as it becomes more difficult for operators to generate cash flow. Shale development has not been led by cash-rich international oil companies but rather smaller, independent US companies, many of which have struggled to generate positive cash flow even in a $\$ 100$ oil price environment; their profitability, debt burdens, and overall financial stability are issues of concern. Because much of the oil boom has been initially funded by debt, operators are now faced with further cash flow constraints as they work to pay off old debt (and accumulate new debt, typically at a higher interest rate). Larger amounts of operating cash flow are being spent repaying or servicing debt instead of investing in operating activities such as drilling or purchasing acreage. Since the collapse in 

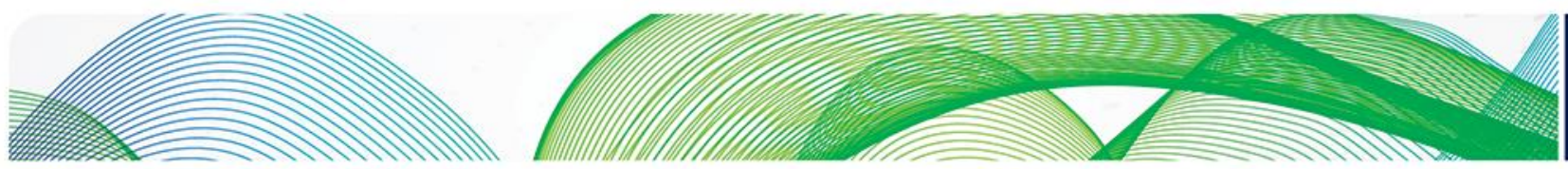

\section{OVI}

oil prices, a handful of companies have filed for bankruptcy. In all likelihood more bankruptcies will occur, but it should be noted that no large independent producers have thus far gone bust. Most bankruptcies have been limited to companies with 20,000 b/d of oil production or less and a portfolio of assets across crude, condensate, natural gas liquids (NGLs), and dry gas, not overly weighted in oil. 

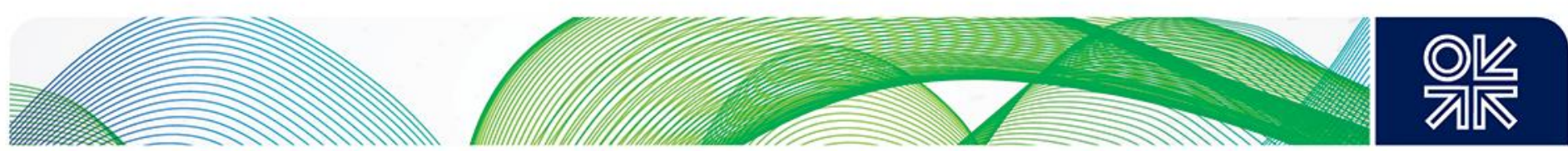

\section{Introduction}

The surge in crude oil production in the US, rising from 5 million barrels a day (mbd) in 2008 to over $9.5 \mathrm{mbd}$ by mid-2015, has been a remarkable achievement of technological innovation and risk-taking in a period of strong and stable oil prices. This liquids growth arrived on the heels of a large-scale development of natural gas supplies from unconventional formations, also known as tight or shale formations. These unconventional petroleum developments are altering flows in world crude oil trade, shifting long-term price expectations, and challenging the long-held conventional wisdom on US energy policy that was promulgated in an era of scarcity. After being written off as a petroleum province undergoing permanent decline, the US now sits alongside Russia and Saudi Arabia as a leading oil and gas supplier ( $13.5 \mathrm{mbd}$ crude oil and liquid fuels production $\left.{ }^{1}\right)$.

Although a large array of forces are at play in driving down world oil prices, one major contributor to the recent fall has been the rapid acceleration of American petroleum production. Lower oil prices in 2015 are bringing large benefits to world consuming centers, but they are also bringing dramatic cuts in capital expenditures for oil and gas development, particularly in the unconventional plays in the United States. The recent decline in oil prices has been met with anticipation of significantly lower levels of US oil production.

One of the biggest unanswered questions facing the market is whether or not relatively high-cost US shale oil production can survive in a relatively low oil price environment (sub $\$ 60$ per barrel). This is the first economic test of the shale oil renaissance. While shale production has thus far proved resilient (due to a combination of factors, such as enhancing efficiency gains, lowering the cost of services, and retreating to the more productive areas), signs of weakness are beginning to show. This paper seeks to answer a number of questions, including:

- Can the efficiency gains made over the past several months sustain current production levels?

- Which of the main shale plays are likely to be impacted the most?

- Will debt levels and bankruptcies put US companies and production at risk?

- Can US shale players assume the role of the swing producer?

This paper will first address the changes in drilling activity and their impact on crude oil production. It will then provide a thorough examination of production and activity levels in the three major US oil plays: the Bakken (Williston Basin), Permian (Permian Basin), and Eagle Ford (Eagle Ford reservoir). The paper will then address the impact of the capital expenditure cuts on production and the US shale sector, and the final section draws some of the main lessons from the current price fall.

\footnotetext{
1 US crude oil and liquid fuels production, EIA (Energy Information Administration), http://www.eia.gov/forecasts/steo/report/us oil.cfm. The US currently produces $9.4 \mathrm{mbd}$ of crude oil and lease condensate. Russian production is currently $10.75 \mathrm{mbd}$ and Saudi Arabia production is currently $10.5 \mathrm{mbd}$ (WSJ). The US is the largest producer of natural gas in the world, currently 89,460 million cubic feet per day gross withdrawals (EIA).
} 

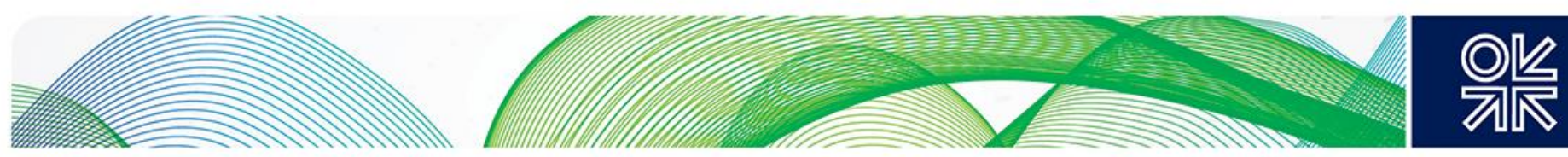

\section{Drilling Activity Changes and the Impact on Production}

\subsection{Tight Oil Play Orientation}

This report focuses on the three areas that have contributed the most to oil production growth in the US: the Bakken formation in the Williston Basin, including North Dakota, eastern Montana, and northern South Dakota (also the Canadian provinces of Saskatchewan and Manitoba); the Permian Basin in southern New Mexico and western Texas; and the Eagle Ford reservoir in south Texas (and partially extending into Mexico). These areas are referred to as oil plays. They have been the focus of unconventional drilling activity since 2008 and are typically referenced as shale or tight oil plays. Other plays and areas of drilling activity, such as the DJ or Denver Julesburg Basin and the Anadarko Basin, are noted in Figure 1 below.

\section{Figure 1: Major Tight Oil Plays in the US}

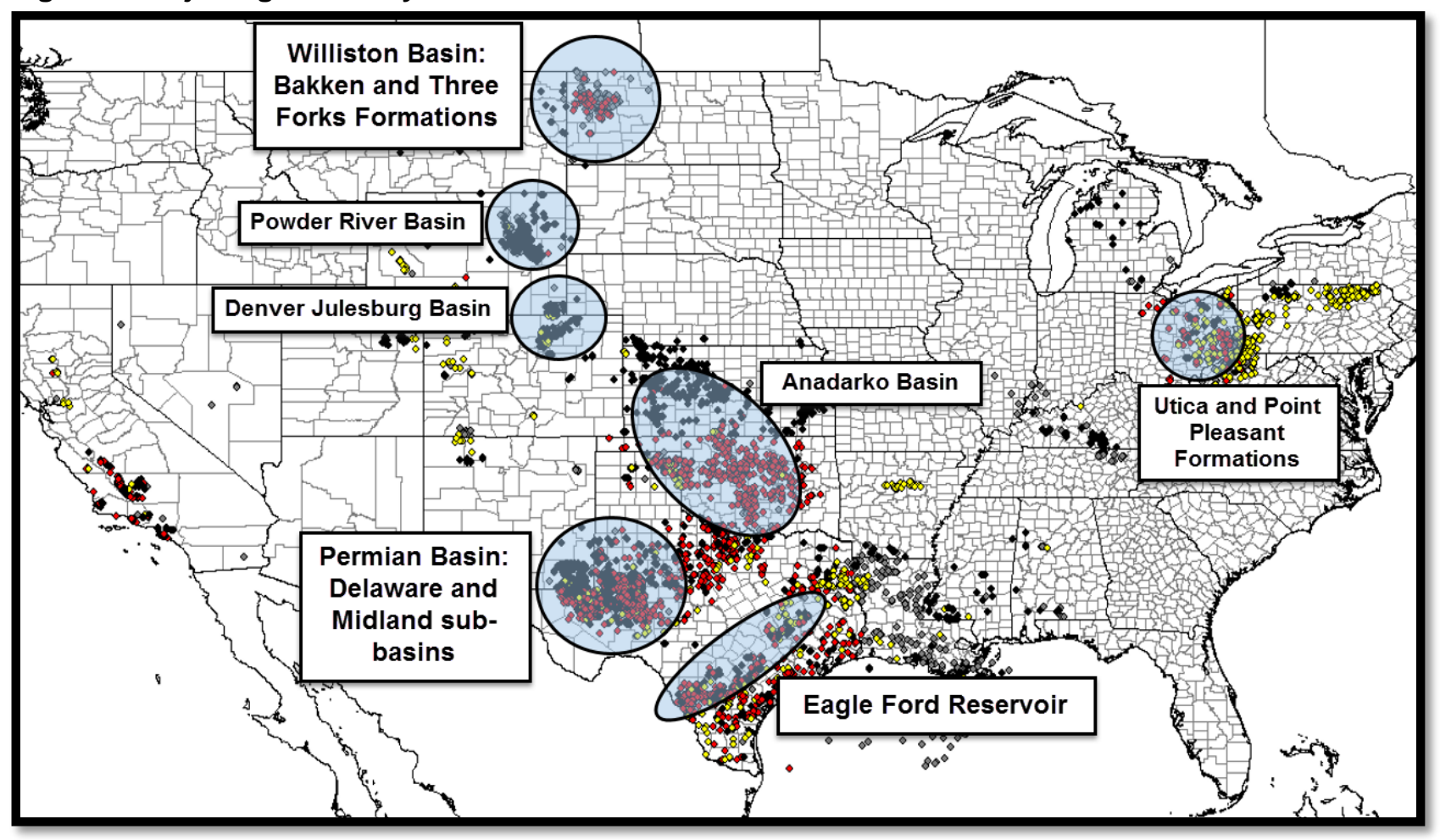

Note: Black dots indicate oil, red dots indicate oil and gas, yellow dots indicate dry gas, and gray indicates all other permits including confidential product status.

Source: Drilling Info, Permits filed in past 90 days (September 2015)

The bulk of US oil production growth has taken place in North Dakota, Texas, and New Mexico. The states shown in Figure 2 below are all part of the unconventional oil boom and have contributed the most growth to US production since 2008. The latest decline in oil prices was preceded by several years of robust drilling activity and consistent oil production growth. High natural gas prices in the 2000s helped spur independent US producers to drill for shale gas in unconventional gas reservoirs thousands of feet below ground, and these technologies were quickly adapted to oil reservoirs. Since 2008, horizontal drilling and hydraulic fracturing has advanced through better drilling rigs, stronger drill 

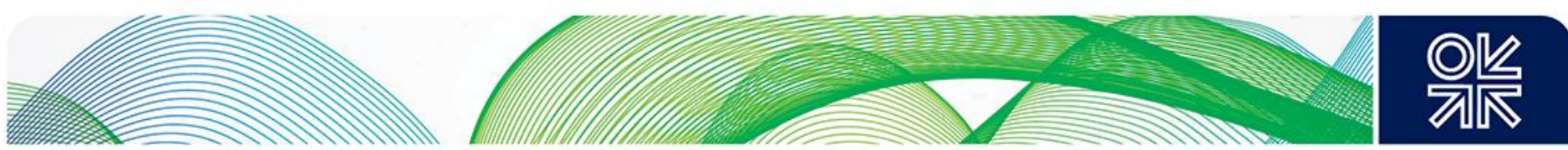

bits, better precision technology, and more efficient use of horsepower. This has led to rising oil production year over year and a dramatic reduction in US crude oil imports, particularly light sweet crude from West Africa. The recent uptick in US crude oil production is attributed to a $150,000 \mathrm{~b} / \mathrm{d}$ increase from June to July in the Gulf of Mexico (Federal Offshore production), largely offsetting recent drops from Texas and other producing states.

Figure 2: US Oil Production: Major Plays and Gulf of Mexico

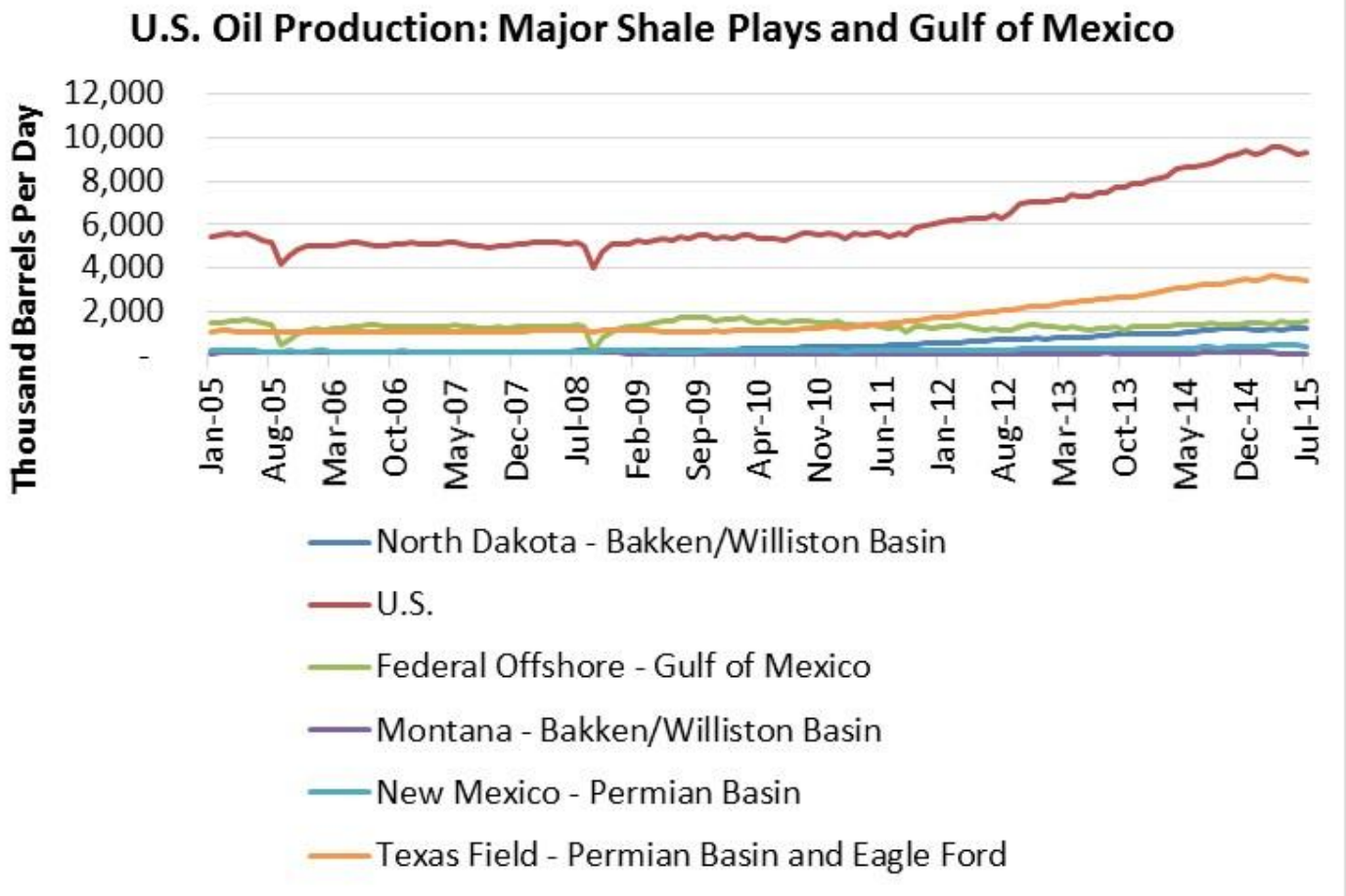

Source: EIA

\subsection{Drilling Activity and Price Changes}

Oil prices dropped in 2008, resulting in a brief pause for the unconventional oil industry. The recovery of oil prices in 2009, from a low in the $\$ 30$ range, resulted in a five-year streak of strong and stable oil prices of approximately $\$ 100$ per barrel. ${ }^{2}$ In July of 2014 , West Texas Intermediate (WTI) crude prices were over $\$ 100$ a barrel and drilling rigs were humming. The rig count rose into August 2014 even as prices first began to falter. It was not until December 2014 that the rig count began declining in response to the drop in oil prices. By January 2015 , WTI had lost $\$ 60$ a barrel ( $\$ 106$ in July to $\$ 46$ in January 2015). Since then the oil rig count has continued to drop. The dry gas rig count has plummeted as well, not supported by less than $\$ 3 / \mathrm{mcf}$ (thousand cubic feet) and lower values for associated liquids. Dry gas has been a further casualty of the oil price decline as oil companies with gas assets pared back their entire portfolios.

\footnotetext{
${ }^{2}$ The recent decline in oil prices has left many drawing comparisons to the price collapse of 2008/09. While there are a few similarities, the current collapse is far different from 2008, when the US unconventional oil sector was in still in its infancy and US oil production had been declining for many years. Today, the industry may still be in the early innings of fundamentally understanding unconventional oil production and what contributes to it, geologically speaking, but the level of development and amount of production is far greater that it was in 2008.
} 

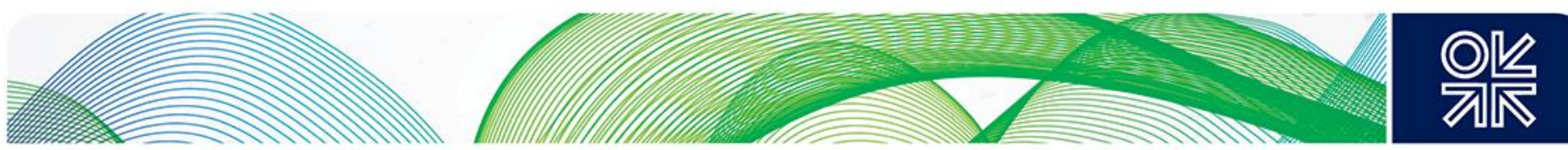

For most operators, the unconventional oil boom in the US has not taken place at oil prices of $\$ 80$ plus; instead, companies in the Rockies, and in North Dakota, have dealt with regional pricing disparities due to infrastructure constraints and bottlenecks. These discounts are in addition to those between global oil prices (Brent) and US oil prices (WTI). In some regions, crude oil is sold well below already discounted benchmarks such as WTI. Compounding the lack of transportation options from the northern tier (the Rockies region and North Dakota) are serious crude oil quality issues. In Texas, for example, large volumes of extremely light crude oil, mostly in the form of condensate, have nearly saturated the Gulf of Mexico refining region. These quality discrepancies have resulted in pricing discounts similar to those seen in North Dakota. Figure 3 below shows the latest full month of pricing data (for September 2015) for Brent, WTI, and prices for crude in local markets. Bakken crude is at the bottom.

Figure 3: Regional Pricing Discounts (\$/barrel)

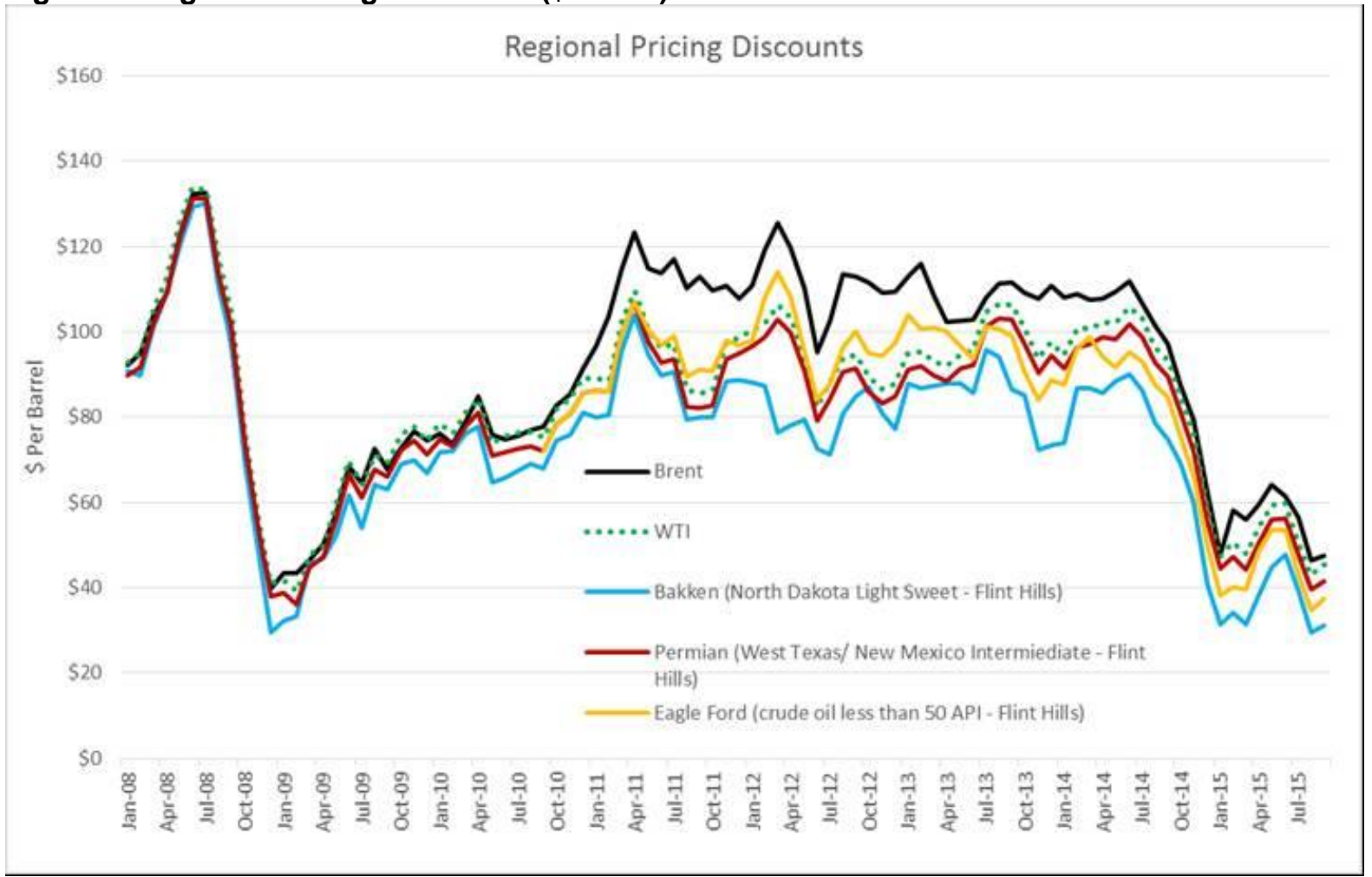

Source: EIA, Flint Hills Resources

\subsection{The Rig Count and West Texas Intermediate}

In 2014 the oil rig count peaked at 1,609 in October, rising from 1,562 in July. After October, the oil rig count began to decline, and by the end of January 2015 some 386 rigs had been shed. Since then, the drop has continued aggressively, hitting a low of 638 oil rigs mid-July (see Figure 4). The last week of July 2015 was marked by small increases in the oil rig count, suggesting to some that the decline was over and stabilization had begun. But oil prices began to fall in July, so when the latest of the rig additions came online, oil had actually dropped into the high $\$ 40$ s. Seventy-nine oil rigs have been cut in just the past eight weeks. It remains unclear where the rig count will head from here, but oil prices of around $\$ 40$ will likely contribute to continual declines in the oil rig count. 

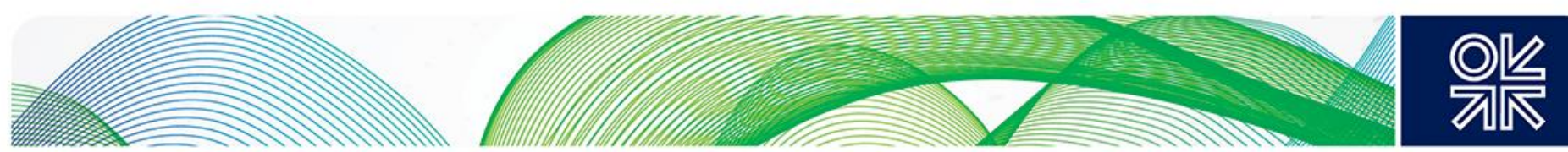

Figure 4: US Oil and Gas Rig Count and WTI Prices

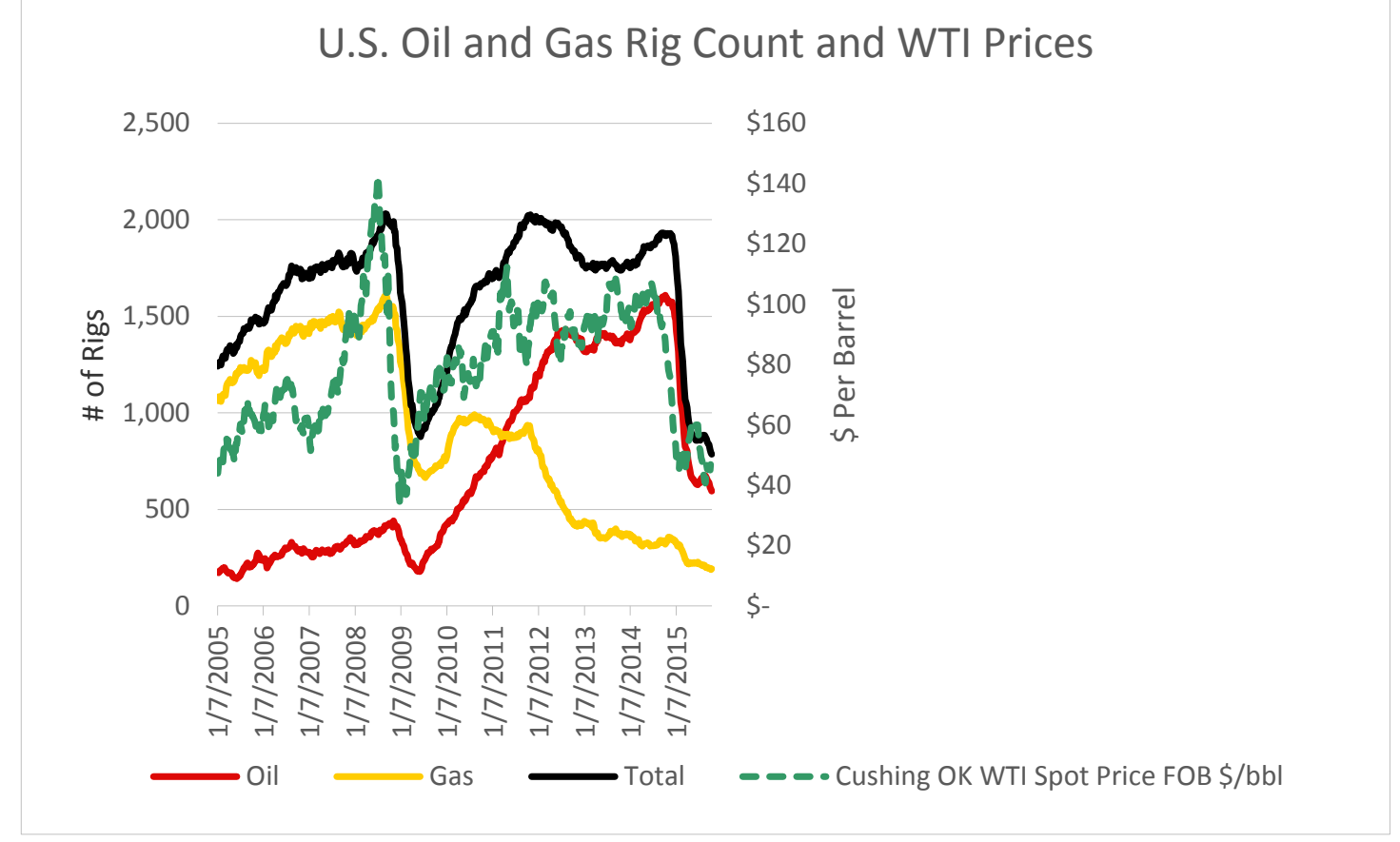

Source: Baker Hughes, EIA

These rig changes are a reflection of individual company strategies and varying market perceptions. Some E\&Ps (Exploration and Production companies) are taking the approach of increasing production despite a low oil price environment, some are paring back and continuing to add wells at a slower rate, and others are simply trying to weather the storm and stay afloat until higher prices return. Despite low oil prices, companies have several incentives to continue drilling and a variety of means to enable them to do so. In many cases, companies are drilling to hold acreage in certain areas as required by their leases and turn a sunk cost into productive value, even if the economics are relatively poor. Rigs are also being maintained in order to delineate assets, particularly in the Permian Basin. ${ }^{3}$ Certain companies seek to maintain positive cash flow to fund ongoing operations, although rig additions might also be funded by debt or stock sales.

\subsection{Contributions to Resilient US Oil Production: Drilling Efficiency Gains and Cost Reductions}

Efficiency gains also helped enable some of these rig additions seen in previous months. Drilling efficiency has improved greatly in recent years, with E\&Ps utilizing some of the most efficient and high-tech rigs available. Better precision drilling capabilities (staying in zone), more efficient utilization of horsepower, and technology which reduces the time between drilling each well have increased efficiencies and reduced drilling times. Producers are also focusing on 'enhanced completions' (pumping massive quantities of sand into the reservoir). This is yielding sharp increases in the initial production rate of wells. (It has yet to be confirmed whether or not this will positively impact the productive life of the well or the Estimated Ultimate Recovery, or EUR, volumes.) 'High-grading',

\footnotetext{
${ }^{3}$ Companies are still actively working to delineate assets, meaning that they are trying to better understand the rock and prove up reserves.
} 

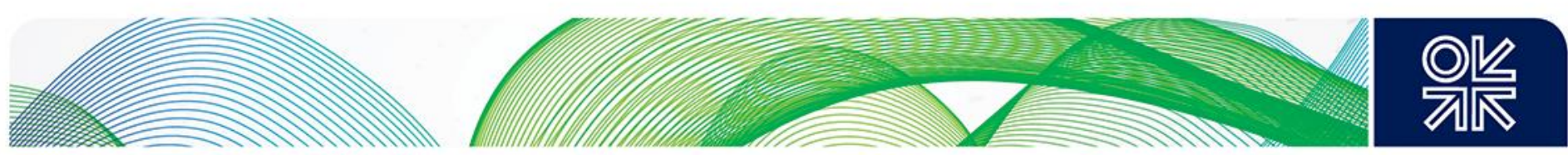

another emerging term, is a reference to companies drilling in their most productive acreage and is an operational method common to most producers.

These and other factors have enabled some E\&Ps to drastically reduce their rig count while still maintaining production levels, in some instances actually increasing production on a quarter-overquarter basis. Another important factor contributing to resilient production is the reduced cost of drilling and completions. Recent earnings calls by both service companies and E\&Ps suggest costs have come down by almost 30 per cent in most areas of the US. Some producers may see higher or lower service cost discounts due to their contract structures, region of drilling, or other factors. These lower costs are being reflected in the total costs to drill and complete a well. Many operators in North Dakota's Bakken play, for example, cited drilling and completions costs around \$2 million lower than last year. They say this is partly due to service cost compression as well as increased operational efficiencies.

\subsection{Financial Capacity of US Independent Oil Companies Proves Resilient}

In addition to unexpected operational efficiencies, many financial and commodity analysts predicted more bankruptcies and asset sales (acreage) of smaller independent oil producers with weak balance sheets and less-than-prime acreage positions. There have been some bankruptcies, but not nearly as many as expected. Moody's rating agency, however, listed the majority of all US corporate family defaults in the second quarter of 2015 as being in the oil and gas sector. ${ }^{4}$ Additionally, several oil and gas companies have been downgraded and put on negative watch, so more bankruptcies and asset sales could be on the horizon. Some companies have missed their bond payments and others have been substantially downgraded due to their high debt levels and lack of liquidity. However, this has not been the case for the majority of independent E\&Ps.

Many publically traded companies have issued more stock in order to raise near-term capital to support drilling programs without adding to their debt load. This has allowed them to continue drilling and actually increase production in the near term, which helps support cash flow (and shareholder optimism and appetite). Companies have also been able to raise capital through debt as investors look for yield and are willing to take on riskier positions in a low interest rate environment. Private equity firms have shored up higher risk companies with special funds and have even purchased E\&Ps outright. While this funding is not limitless, this is a liquid market with ample investment opportunities and plenty of appetite for risk.

\subsection{The Rig Count Decline and Oil Production}

Many independent operators have been noting their optimism and capacity to handle this price decline while maintaining production levels. Multiple producers indicated during their second-quarter earnings calls that they plan to keep quarter-over-quarter production steady, while the rest suggested slight increases and/or decreases. The main takeaway was that few, if any, companies planned for major production alterations. ${ }^{5}$

Weekly production and weekly rig count data would certainly support company assertions that production can remain relatively unaffected with a reduced rig count. Two main factors, among others,

\footnotetext{
${ }^{4}$ Moody's Investor Service, 30 July 2015, Sector In-Depth report.

${ }^{5}$ Keep in mind that these statements reflected second quarter 2015 oil prices that had recovered slightly from the first quarter As these earnings were released, prices were dropping well into the mid \$40s. August 2015 saw several days of WTI prices below $\$ 40$.
} 

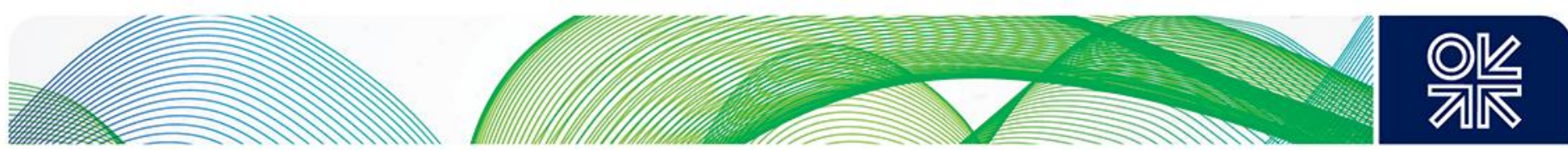

support this theory: first, many of the rigs currently drilling today are the most efficient ones on the market; and second, some of the larger service companies have been able to provide substantial discounts as well as free products. These cost cuts and freebies (along with the service company's desire to weather the storm and maintain market share) could certainly have a positive impact on production figures. However, because today's production is generated from drilling activity months ago, it is important to consider what today's rig count tells us about future production levels. ${ }^{6}$

Table 1 below shows US monthly production data and the average monthly oil rig count with an adjusted three-month lag ( 90 days being a rough estimate of the time it would take to complete a well after drilling). ${ }^{7}$ Therefore, July production data reflects production generated from rigs active in April, when the average oil rig count was still relatively high, at 750 . With this method of examining the relationship between rig count and production, 750 rigs helped contribute to July's $9.35 \mathrm{mbd}$ figure. However, July's active oil rig count by comparison was just 649. The production impact of this steep drop in active rigs will not be available until October's production data is released, most likely available in December. Although it is true that more is being done with less and that rig efficiency continues to improve, it is doubtful that improved efficiencies can overcome the continual loss of rigs, particularly given the steep decline rates associated with tight oil wells. Keep in mind that there are a significant amount of wells waiting on completion (WOC, or wells that have been drilled but are yet not completed and brought onto production), which is also a factor in future production volumes. The number of wells waiting on completion has continued to grow in the last several months as producers lock in discounted rates for drilling operations and wait to spend additional capital on fracturing and completing the well and bringing it onto production. ${ }^{8}$

\footnotetext{
${ }^{6}$ The latest full month of production data is from July 2015. Monthly production data lags by about two months (varying according to state requirements). July oil production from EIA is $9.35 \mathrm{mbd}$, up from $9.26 \mathrm{mbd}$ in June, largely due to an increase in Gulf of Mexico production, despite declines in many shale regions.

${ }^{7}$ Estimates between spudding a well and bringing it onto production vary between three and six months and depend upon a number of factors including the availability of frac and other service crews and equipment.

${ }^{8}$ Completion practices are estimated to be roughly half the cost of total drilling and completions activities.
} 

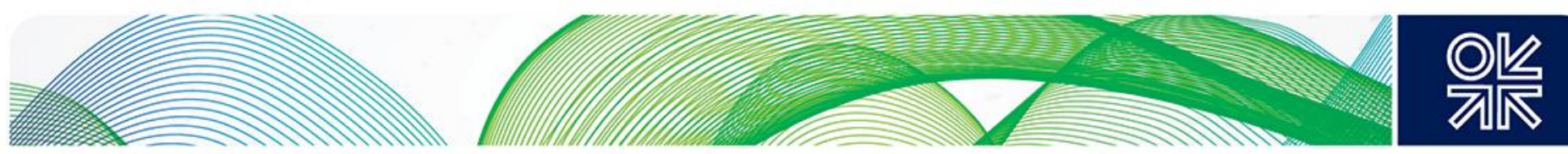

Table 1: US Production and Oil Rig Count

\begin{tabular}{|c|c|c|c|}
\hline $\begin{array}{l}\text { Month - Oil } \\
\text { Production }\end{array}$ & $\begin{array}{l}\text { U.S. Oil } \\
\text { Production b/d }\end{array}$ & Month - Rig & U.S. Oil Rig Count \\
\hline Jan-14 & 8,031 & Oct-13 & 1,364 \\
\hline Feb-14 & 8,130 & Nov-13 & 1,384 \\
\hline Mar-14 & 8,253 & Dec-13 & 1,396 \\
\hline Apr-14 & 8,537 & Jan-14 & 1,403 \\
\hline May-14 & 8,605 & Feb-14 & 1,424 \\
\hline Jun-14 & 8,678 & Mar-14 & 1,466 \\
\hline Jul-14 & 8,748 & Apr-14 & 1,515 \\
\hline Aug-14 & 8,830 & May-14 & 1,530 \\
\hline Sep-14 & 8,956 & Jun-14 & 1,545 \\
\hline Oct-14 & 9,123 & Jul-14 & 1,560 \\
\hline Nov-14 & 9,199 & Aug-14 & 1,578 \\
\hline Dec-14 & 9,430 & Sep-14 & 1,529 \\
\hline Jan-15 & 9,262 & Oct-14 & 1,593 \\
\hline Feb-15 & 9,341 & Nov-14 & 1,573 \\
\hline Mar-15 & 9,560 & Dec-14 & 1,539 \\
\hline Apr-15 & 9,601 & Jan-15 & 1,362 \\
\hline May-15 & 9,379 & Feb-15 & 1,050 \\
\hline Jun-15 & 9,264 & Mar-15 & 857 \\
\hline Jul-15 & 9,358 & Apr-15 & 750 \\
\hline Aug-15 & & May-15 & 662 \\
\hline Sep-15 & & Jun-15 & 634 \\
\hline Oct-15 & & Jul-15 & 649 \\
\hline Nov-15 & & Aug-15 & 671 \\
\hline Dec-15 & & Sep-15 & 650 \\
\hline Jan-16 & & Oct-15 & \\
\hline
\end{tabular}

Source: EPRNC estimate, EIA production data, Baker Hughes rig count

In each oil play, a certain amount of new wells need to be completed and brought into production each month to offset production declines from older wells. Despite drilling efficiency gains, the dramatic reduction in the rig count and the subsequent monthly oil production declines, seen in the May and June data, reflect the simple truth that the rig count is too low and not enough new wells are being brought into production each month: further production declines are imminent. Figure 5 below is a forecast of 2015 and early 2016 oil production assuming gradual continuing declines in the oil rig count and a roughly $125,000 \mathrm{~b} / \mathrm{d}$ production decline each month. At this rate, March oil production in 2016 would be $8.36 \mathrm{mbd}$, a decline of over $1.2 \mathrm{mbd}$ from April 2015's 9.6 mbd peak. 

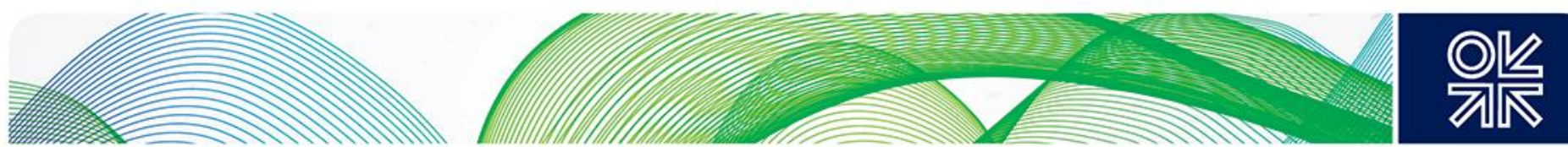

Figure 5: US Oil Production and Forecast (thousand b/d)

\section{U.S. Production and Forecast}

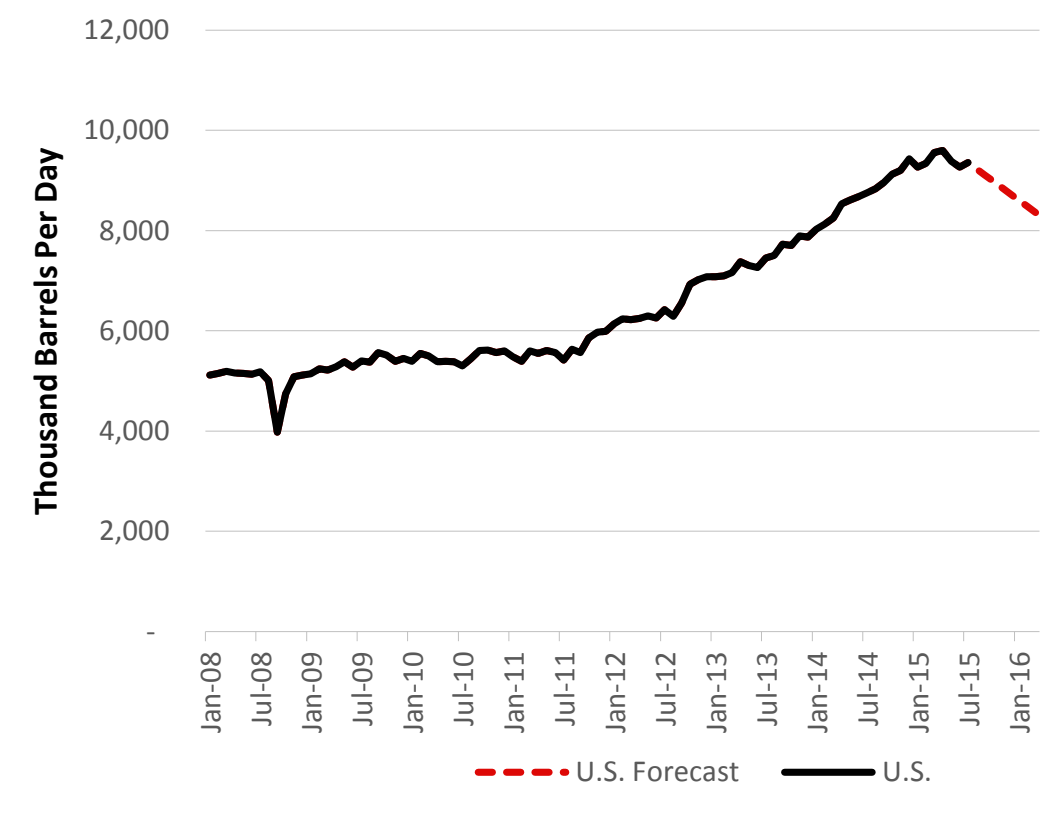

Source: EIA, EPRINC forecast

\section{Breaking Down the Three Major US Tight Oil Plays: The Williston Basin (the Bakken)}

The Bakken is one of the most prolific shale oil plays to date; it spurred the unconventional oil revolution. The Williston Basin spans territory in North Dakota, eastern Montana, and a small portion of northern South Dakota (in addition to portions in Saskatchewan and Manitoba in Canada). It is home to the Bakken and Three Forks reservoirs and is often referred to simply as the Bakken shale oil play. North Dakota is home to the majority of Williston Basin production and has been the strongest growth area for many US independent oil companies.

\subsection{Production Overview}

Crude oil production has averaged approximately $1.2 \mathrm{mbd}$ in North Dakota for the past 12 months, ranging between $1.1 \mathrm{mbd}$ to just over $1.2 \mathrm{mbd}$ according to state data. The latest figure for August production in North Dakota is 1.186 mbd, a slight decline from $1.207 \mathrm{mbd}$ in July. Typically, summer production in North Dakota and the entire Williston Basin results in significant increases due to warmer and dryer weather. Total Williston Basin production has declined slightly, which indicates slower activity in eastern Montana. Anecdotal evidence suggests that Bakken barrels being sold in Clearbrook, Minnesota, a major hub for Bakken crude which historically discounts Bakken barrels, are only slightly discounted. This may indicate a reduction in Bakken volumes flowing through Enbridge's 

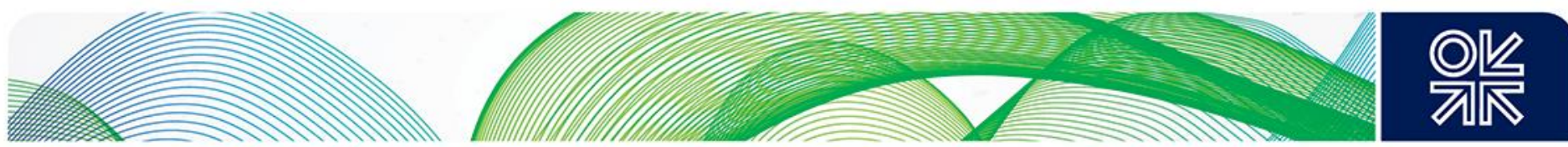

pipeline system and a reduction in overall production volumes not yet seen in current production data. Figure 6 shows total Williston Basin production from 2000. ${ }^{9}$

Figure 6: Williston Basin Production (b/d) and Number of Wells

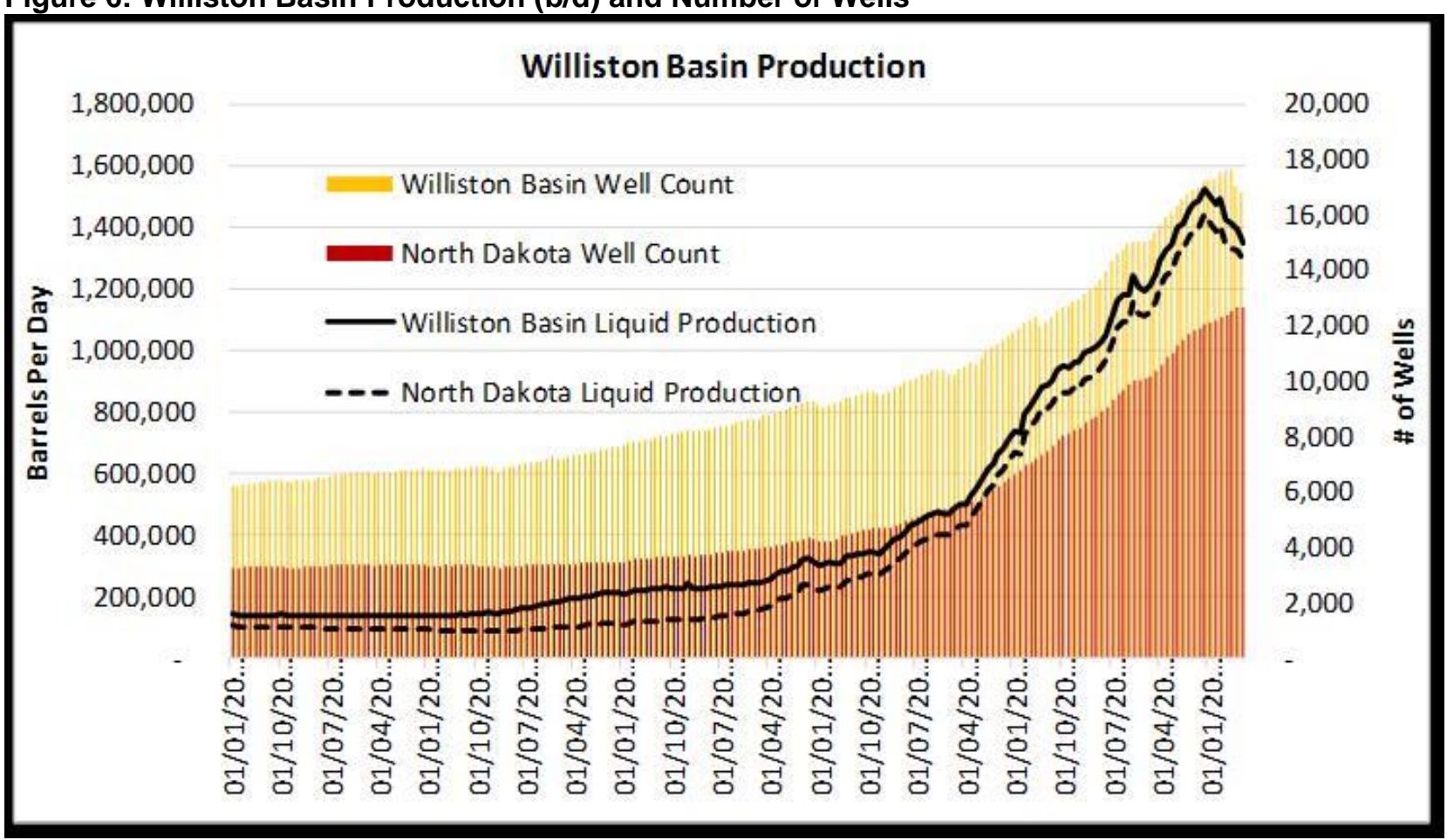

Source: DrillingInfo data, 13 October 2015

North Dakota's steady production growth through December of 2014 correlates with exceptionally stable drilling activity from the end of 2013 through 2014 (as shown in Table 2). In fact, the rig count stayed consistently above 188 from October 2013 until December of 2014, when it dropped to 181 and then rose again in January 2015 to 188. It was not until February 2015 that North Dakota began to aggressively shed rigs. September's average rig count was just $71-117$ rigs less than January. North Dakota produced 1.186 mbd in August, the latest available month of production data. Assuming a 90-day lag time for completion activities after drilling, August production was supported by a rig fleet of 83 in May rather than the 74 rigs active in August. Despite the significant strides made in drilling efficiencies, it is likely that production in North Dakota will continue to recede in coming months due to the falling rig count (as well as the rising number of wells waiting on completion). 

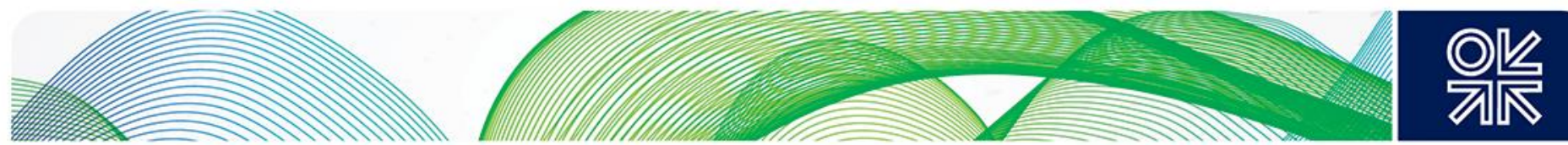

Table 2: North Dakota Oil Production and Rig Count

\begin{tabular}{|c|c|c|c|}
\hline $\begin{array}{l}\text { Month - Oil } \\
\text { Production }\end{array}$ & $\begin{array}{l}\text { North Dakota Oil } \\
\text { Production b/d }\end{array}$ & Month - Rig & ND Rig Count \\
\hline Jan-14 & 937,200 & Oct-13 & 188 \\
\hline Feb-14 & 953,305 & Nov-13 & 189 \\
\hline Mar-14 & 976,798 & Dec-13 & 193 \\
\hline Apr-14 & $1,004,255$ & Jan-14 & 187 \\
\hline May-14 & $1,040,625$ & Feb-14 & 189 \\
\hline Jun-14 & $1,092,922$ & Mar-14 & 190 \\
\hline Jul-14 & $1,114,521$ & Apr-14 & 187 \\
\hline Aug-14 & $1,132,842$ & May-14 & 189 \\
\hline Sep-14 & $1,186,328$ & Jun-14 & 190 \\
\hline Oct-14 & $1,183,586$ & Jul-14 & 192 \\
\hline Nov-14 & $1,188,258$ & Aug-14 & 193 \\
\hline Dec-14 & $1,227,344$ & Sep-14 & 195 \\
\hline Jan-15 & $1,191,374$ & Oct-14 & 191 \\
\hline Feb-15 & $1,178,334$ & Nov-14 & 188 \\
\hline Mar-15 & $1,190,612$ & Dec-14 & 181 \\
\hline Apr-15 & $1,169,045$ & Jan-15 & 188 \\
\hline May-15 & $1,202,615$ & Feb-15 & 133 \\
\hline Jun-15 & $1,211,178$ & Mar-15 & 108 \\
\hline Jul-15 & $1,206,966$ & Apr-15 & 91 \\
\hline Aug-15 & $1,186,444$ & May-15 & 83 \\
\hline Sep-15 & & Jun-15 & 78 \\
\hline Oct-15 & & Jul-15 & 73 \\
\hline Nov-15 & & Aug-15 & 74 \\
\hline Dec-15 & & Sep-15 & 71 \\
\hline Jan-16 & & Oct-15 & \\
\hline
\end{tabular}

Source: North Dakota Industrial Commission (NDIC) production and rig data

\subsection{Bakken Production and Top Producers}

The Bakken was the first major shale oil play to take off. As a result, many operators were able to lock up large acreage positions at favorable prices early in the shale rush. Over time, some of these companies were able to add to their acreage positions through 'bolt-on' purchases. Hess actually has legacy assets in the core of the Bakken which date back to the formation's discovery in the 1950s. The majority (over two-thirds) of Bakken production lies in the hands of just 10 operating companies. Therefore, production growth and overall activity levels (in terms of drilling and completions) are dependent upon these top 10 companies. Their internal strategies, exposure across the US and internationally, access to capital, and overall liquidity all factor into activity levels in the Bakken. ${ }^{10}$ For example, ConocoPhillips, one of the top 10 producers, is a major oil company with significant US and global assets. This company is greatly reducing its rig count in the Bakken and across the United

\footnotetext{
${ }^{10}$ Some major operators have had to dramatically reduce capital expenditures in the US because they are unable to reduce spending abroad as quickly. Drilling and completion costs have not come down around the globe nearly as much as they have in the US. The United States has a very nimble oil and gas service sector which can quickly respond to a reduction in oil prices. This does not exist in many other parts of the world. Additionally, offshore and deepwater projects have a more sticky cost structure than onshore, due to inherent costs of doing business including flying to and from an offshore rig etc.
} 

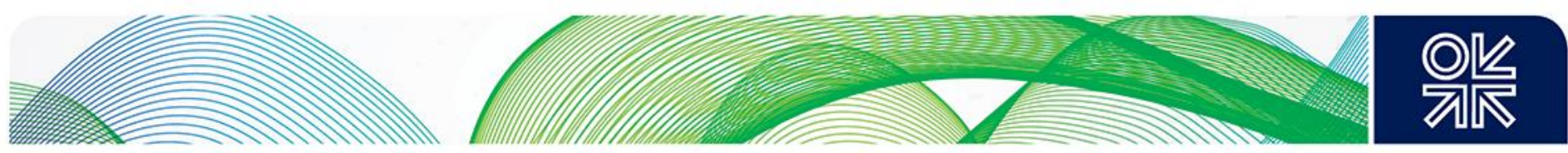

States (from 32 rigs in the Bakken, Eagle Ford, and Permian at the end of 2014 to just 13). ${ }^{11}$ Figure 7 shows total production, production by top 10 producers, and production by all other producers. The top 10 producers contribute about $900,000 \mathrm{~b} / \mathrm{d}$ to total production volumes of $1.2 \mathrm{mbd}$ in the Williston Basin. All of the other producers in the Williston Basin only produce about $340,000 \mathrm{~b} / \mathrm{d}$.

Figure 7: Production Allocation by Top 10 Producers (b/d)

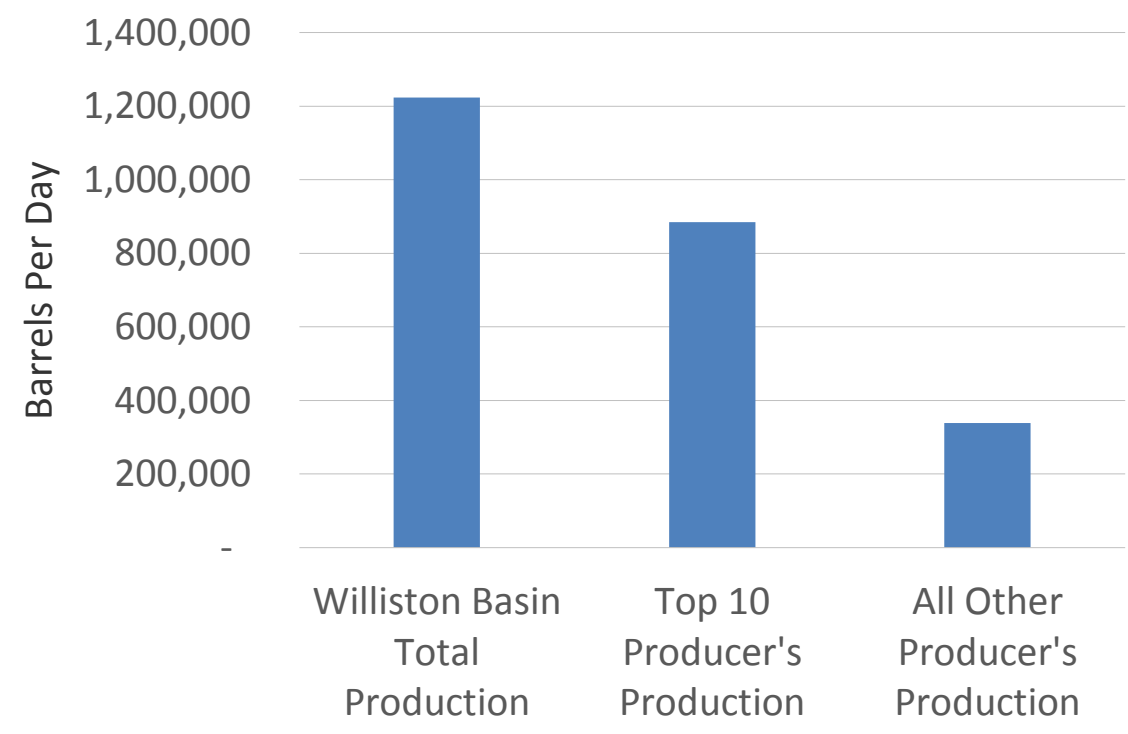

Source: Production data provided by PetroNerds and given to EPRINC (October 2015)

Highly consolidated production volumes have had a mixed impact on the Bakken. This latest oil price downturn has spurred companies to pursue 'organic growth', meaning growth in reserves, drillable locations, and future production potential from existing assets. This is leading to deeper and more sophisticated data analysis and asset delineation in both the Bakken and the Three Forks formations (right beneath the Bakken, the Three Forks formation has multiple producible oil benches, but as the depth increases so does the cost. Many of these benches have not been aggressively analyzed). However, because these companies have been active since 2008 or earlier, many producers already hold their acreage by production, which means that they are not required to keep drilling in order to maintain their acreage positions. They can deploy capital to other existing assets, like the Permian Basin, where their acreage may not be fully held by production. While most of these companies in their second-quarter conference calls committed to at least maintaining production levels in the Bakken throughout 2015, some forecasted slight declines. Many of these operators plan on maintaining roughly the same rig count as they have right now, however this could easily change as oil prices remain in the $\$ 40$ range. Figure 8 below shows rig allocation by total production, top producers, and other producers in the Williston Basin. The top 10 producers in the Bakken account for over 70 per cent of current drilling activity (49 of 68 rigs $^{12}$ ).

\footnotetext{
11 ConocoPhillips second-quarter earnings/conference call, Seeking Alpha.

12 Drillinglnfo's rig count (currently at 68 for 16 October 2015) is often slightly higher than Baker Hughes (64), shown below, because it includes all drilling rigs including workover and surface casing rigs.
} 

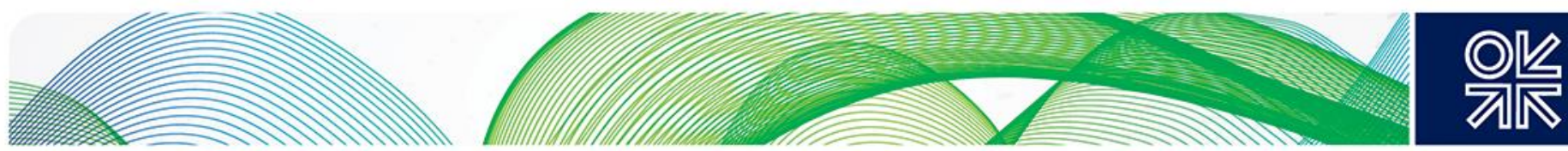

Figure 8: Rig Allocation by Top producers (b/d)

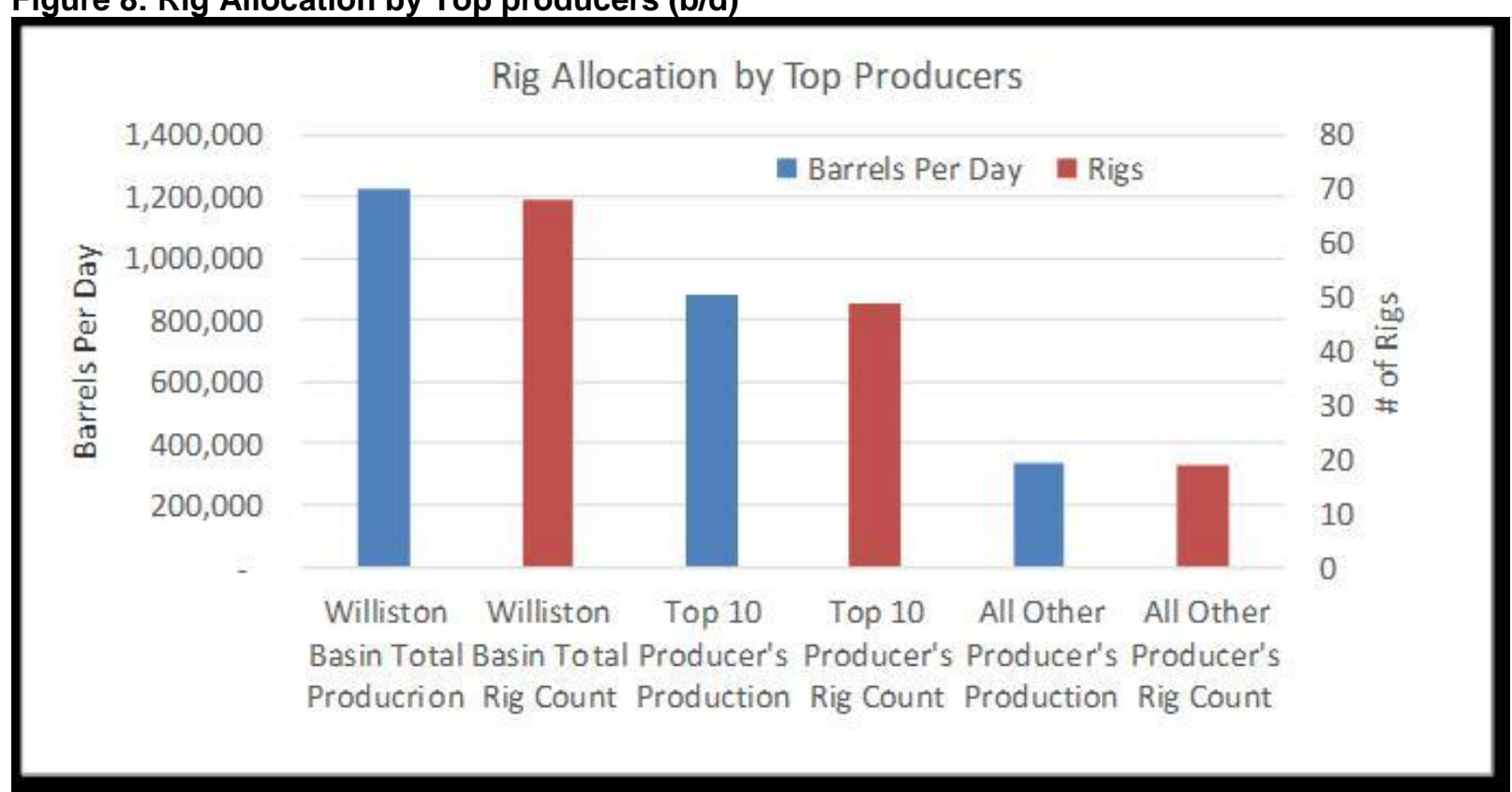

Source: Production data provided by PetroNerds and given to EPRINC (October 2015), DrillingInfo rig data (16 October 2015)

\subsection{Bakken In-Depth}

Most second-quarter conference calls noted a lack of planned production increases across the Bakken, Permian, and Eagle Ford. It was clear that companies are in fact drilling and producing more oil with fewer rigs. Many of the rigs drilling today are 'fit-for-purpose' rigs with better precision technology that allows drillers to drill more accurately 'in zone'. There is an acute focus on reducing costs, spending capital more efficiently, and increasing initial production volumes. In the Bakken, many companies utilize 'enhanced completions' - a term which refers to operators pumping large volumes of proppant per lateral foot, in some cases 1,000 to 2,000 pounds of sand per foot. Almost all of these enhanced completions are using sand instead of resin-coasted sand or ceramic proppant due to raw sand's favorable price. These enhanced completions are resulting in large increases in initial production rates, thus boosting cash flows in the near term. However, whether enhanced completions yield an increase in overall production throughout the life of the well, the EUR (estimated ultimate recovery), is not yet determined.

A Williston Basin producer's comments on enhanced completions:

The big change really is with the enhanced completions, we're pumping a lot more sand and getting a lot higher rates...we just think what's happening there is we're doing a much better job of breaking up the reservoir and accessing a lot more of the reservoir upfront, and that's what's responsible for the increase in rates. So early to say what's - exactly how much the EURs are going to go up, but the critically important part of this whole thing is that our nearterm rates are going up quite substantially and contribute to much better cash flow.

Whiting Petroleum, second-quarter earnings/conference call, Seeking Alpha 

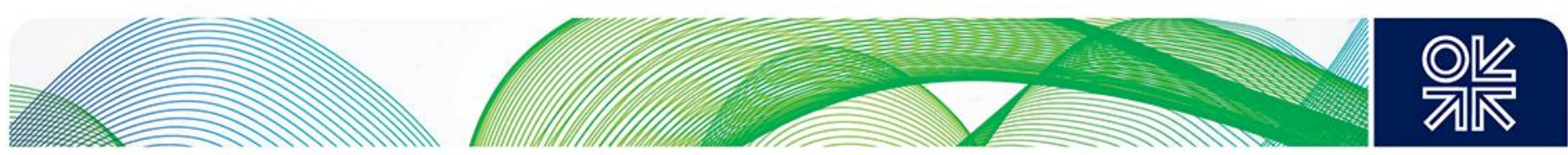

Other buzzwords in earnings calls included 'high-grading' and 'high-density completions'. Highgrading refers to the targeting of core acreage in the current drilling and completion plan in order to ensure strong production results despite low oil prices. Producing from strong assets with high production volumes can reduce break-even costs. Not all producers have taken this approach, however. Admittedly, most companies are looking to maximize their current production capacity, but at least two top Bakken producers expressed disinterest in drilling and producing from their best assets in a low oil price environment.

High-density completions, referring to reducing spacing between wells, have been utilized in the Bakken for the past several years, but operators are now more aggressively integrating them into their full completion designs. Instead of trying to create long fractures from the wellbore, operators are now targeting smaller and more complex fractures around the wellbore. This allows them to place wellbores closer together because larger fracs will not cause wells to communicate (increasing pressure in one well and decreasing it in another). They believe this is allowing them to drain more of the rock closest to the wellbore. These well placement designs allow for further cost efficiencies; above-ground rig movements are reduced because wells are drilled closer together, simultaneous well completions are possible, and the integration of oil, water, and gas infrastructure becomes simpler.

\subsection{Recent Activity and Well Performance}

Is the overall production performance of a given well increasing due to these noteworthy enhancements? While many wells are still under confidential status, and production data lags two months behind, a significant portion of 2015 data is available, and it is a good representation of new production in a lower oil price environment (note that the first half of 2015 was in the $\$ 50$ s not the current $\$ 40$ s). The map below shows all wells brought onto production beginning 1 January 2015. The majority of new wells are in Williams, McKenzie, Mountrail, and Dunn counties. This area represents 'core' Bakken acreage. The Bakken 'core' typically refers to the thermally mature portion of the Bakken formation and correlates to strong well performance. 

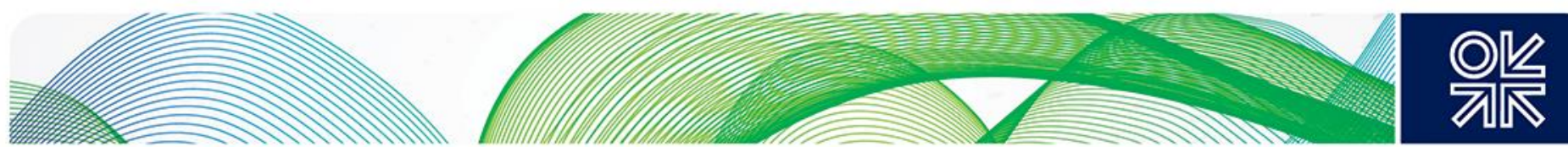

Figure 9: Wells Brought Back into Production Beginning January 2015, Bakken

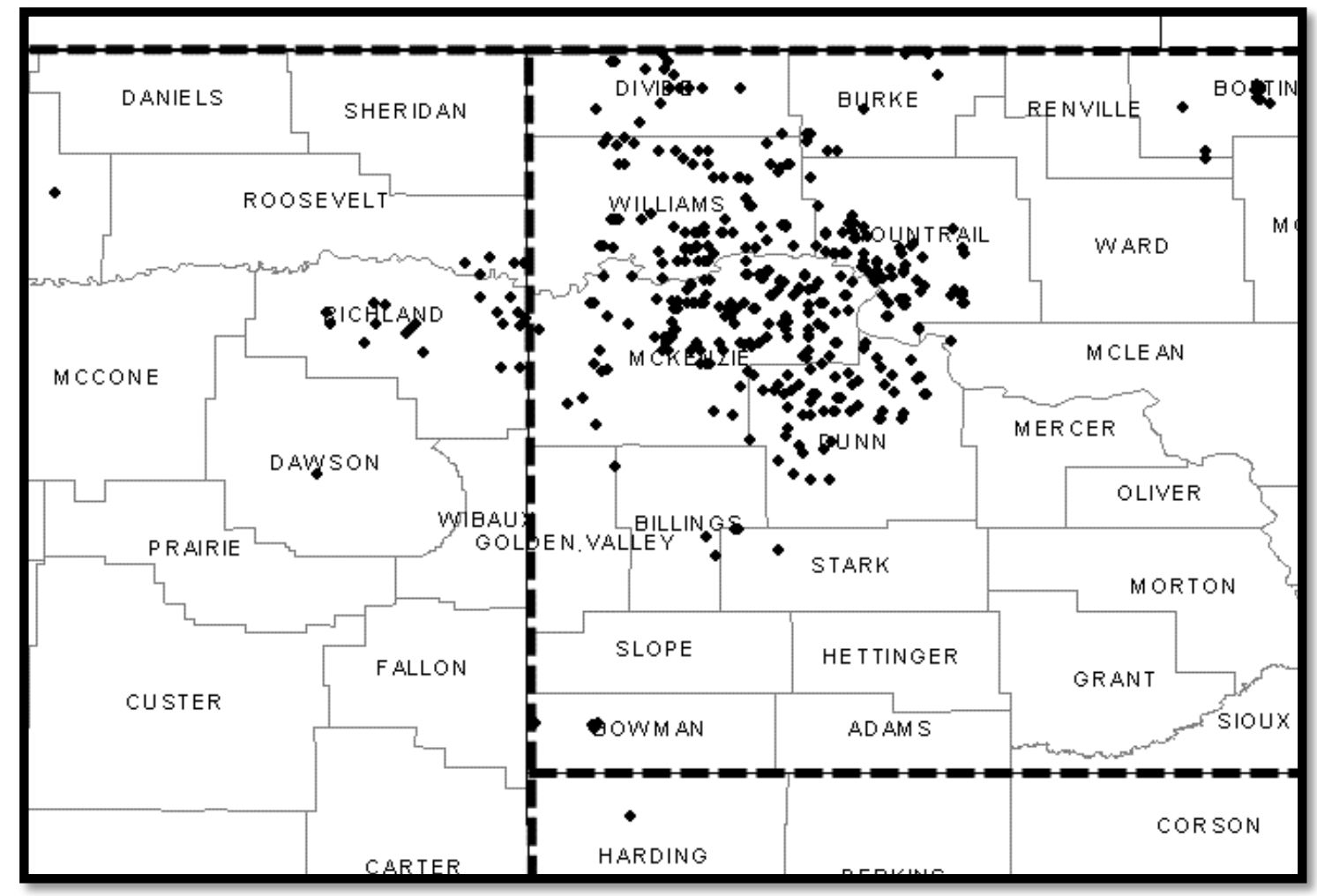

Source: Drillinglnfo, All wells brought onto first production starting 1 January 2015 (15 October 2015)

In terms of production performance, Williston Basin wells surpass their peers in the Permian and in the Eagle Ford. The average initial production rate (IP) for Williston Basin wells has grown dramatically over the past year compared to the preceding years. Wells drilled in 2015 are averaging $653 \mathrm{~b} / \mathrm{d}$, an $88 \mathrm{~b} / \mathrm{d}$ IP increase over 2014 wells. The structural decline of these wells has not changed over the past three years, and this is illustrated in the type/decline curve (Figure 10). Several months of additional production data will be needed to fully analyze the impact of enhanced completion techniques. Many 2015 wells are still under confidential status, but the 2015 activity map and the increase in North Dakota well performance does suggest that high-grading is taking place. Fewer wells are being drilled, but the ones that are coming online are performing better in terms of initial production volumes. North Dakota's average IP rate has also increased substantially, by $84 \mathrm{~b} / \mathrm{d}$, from $585 \mathrm{~b} / \mathrm{d}$ in 2014 to $669 \mathrm{~b} / \mathrm{d}$ in 2015 (shown in Figure 11). 

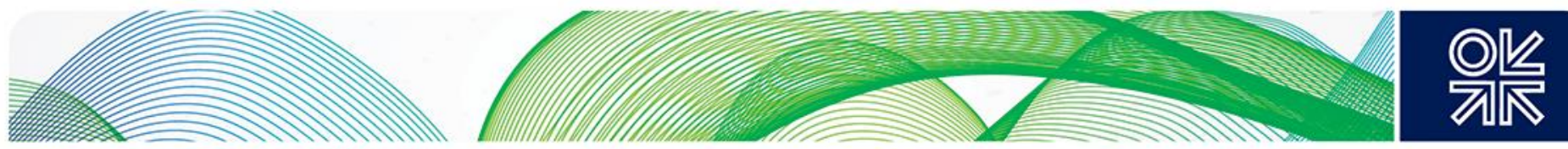

Figure 10: Williston Basin Production Type/ Decline Curves (b/d)

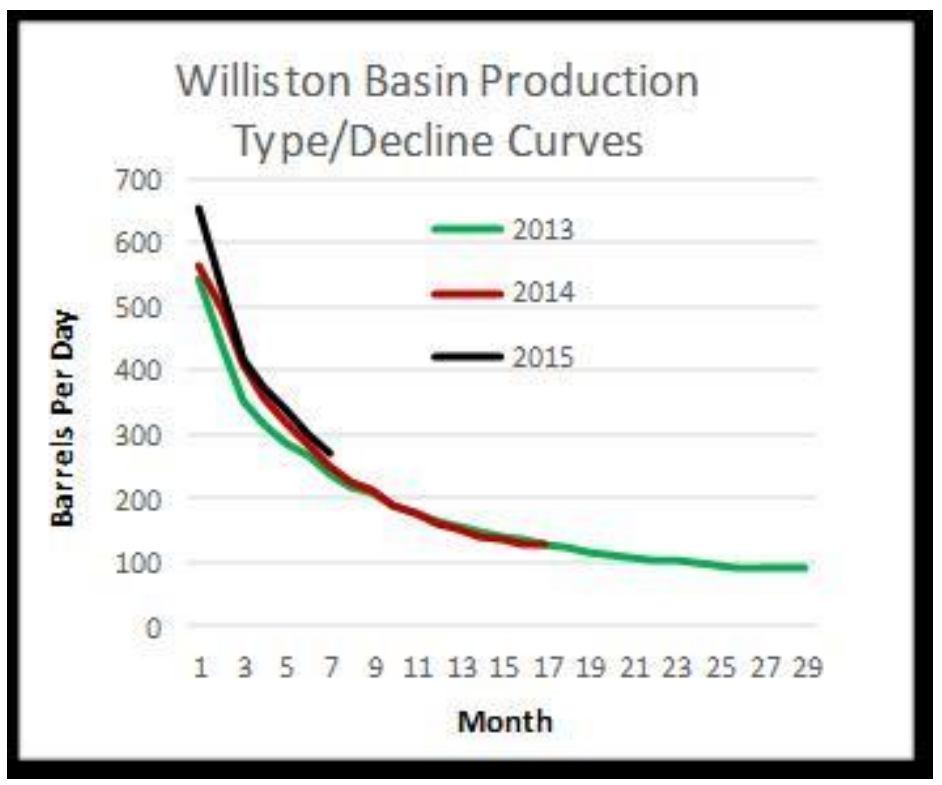

Figure 11: Williston Basin Production Initial Production Rates (b/d)

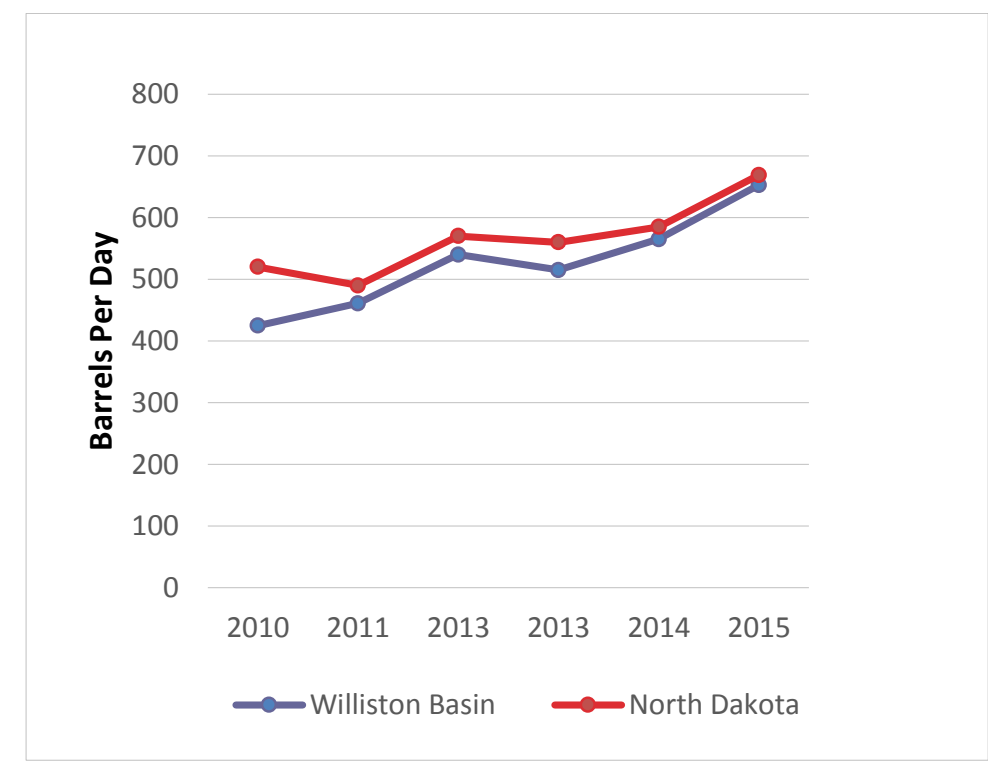

Source: DrillingInfo data and EPRINC estimates (14 October 2015)

\subsection{Permits and Rig Count}

The rig count has declined by more than two-thirds since October 2014. More wells are waiting on completion (WOC), the amount of permits being filed is decreasing, and the amount of spudded wells is decreasing. All of these factors suggest that a continual decline in production is extremley likely over the coming months unless there are substantial changes in oil prices and oilfield activity. Figure 

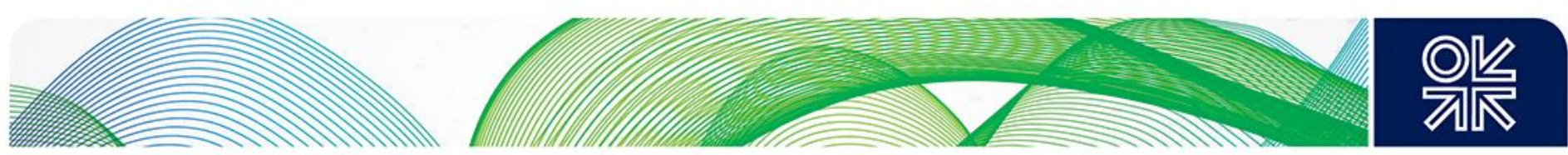

12 below shows the dramatic decline in the Williston Basin rig count, which currently totals 64 rigs (16 October 2015), down from a recent high of 198 in October 2014. ${ }^{13}$ Again, the focus is on the core area of the Bakken, with the majority of rigs in Mckenzie, Dunn, Mountrail, and Williams counties. All but one of the rigs are currently drilling in North Dakota.

\section{Figure 12: Williston Basin Rig Count}

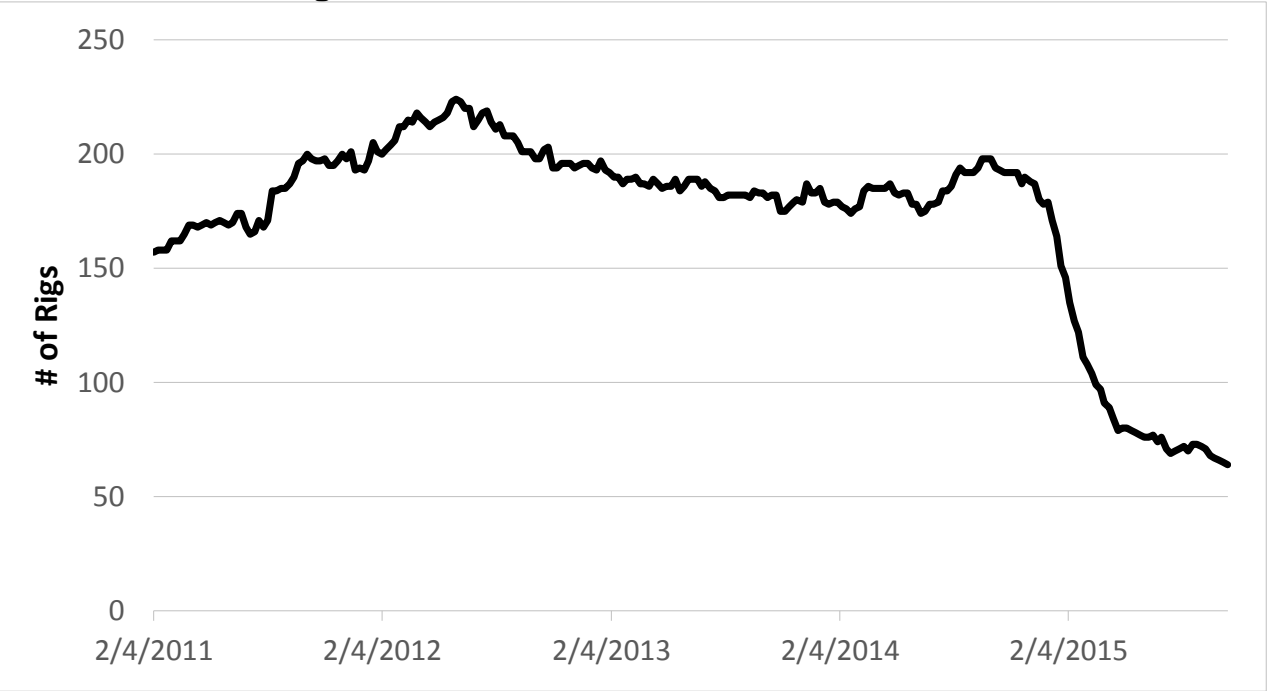

Source: Baker Hughes, Williston Basin oil rig count

Taken together, rig and permit data illustrate a significant reduction in current and future drilling activity. Figure 13 below displays yearly data for total permits filed, total spuds, average annual rig count, and estimated wells that are drilled but waiting on completion in North Dakota. The column representing 2015 shows the current data for January through August. In the first eight months of 2015 , some 1,536 total drilling permits were filed. Over 1,400 additional permits would need to be filed before year-end to meet 2014's peak of 3,009. Only 984 wells were spudded from January through August of 2015, compared to a total of 2,624 wells spudded in all of 2014. Should North Dakota's current 2015 spud count double, it would be 656 spuds shy of 2014. Additionally, Williston Basin total permit filings for the past 90 days are down considerably - from 730 in mid-February to 502 as of 16 October 2015. ${ }^{14}$

The amount of estimated WOCs, shown in the black outlined column, has increased dramatically in 2015 and represents an eight-month average (January to August 2015), currently at 889. As indicated in the figure below, the number of WOCs increased considerably from 2012 to 2015 , long before the decline in oil prices. This is partly due to significant drilling efficiency gains over the past few years that have led to a decrease in the time it takes to drill a well from spud to total depth (TD). That time further decreased in 2015 as drillers were incentivized to cut costs, resulting in an increase in the number of WOCs. Prior to the decline in oil prices in 2014, most wells waiting on completion were a result of logistical challenges and frac crew shortages due to the frenzy of drilling activity. Now, wells waiting on completion are largely the result of operators becoming more selective, as completion costs are estimated to comprise roughly 50 per cent of the total drilling and completion cost (if a well in North Dakota now costs $\$ 7$ million then about $\$ 3.5$ million is spent on drilling). The number of wells waiting on completion in North Dakota for the month of August is estimated to be $993 .{ }^{15}$

\footnotetext{
${ }^{13}$ Total rig count according to Baker Hughes.

${ }^{14}$ Drilling Info permit data, all permits filed in the past 90 days.

${ }^{15}$ North Dakota Industrial Commission (NDIC).
} 

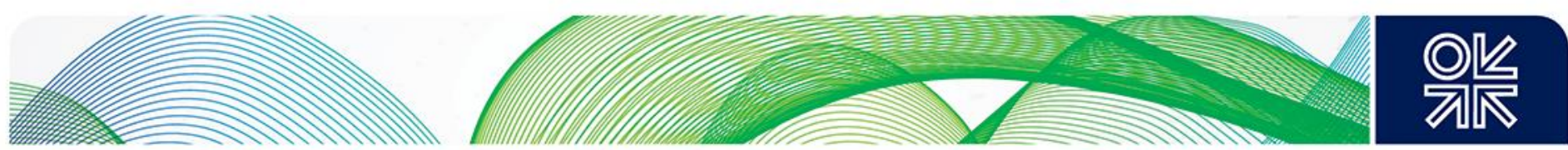

Figure 13: North Dakota: Spuds, Permits, and Rigs,

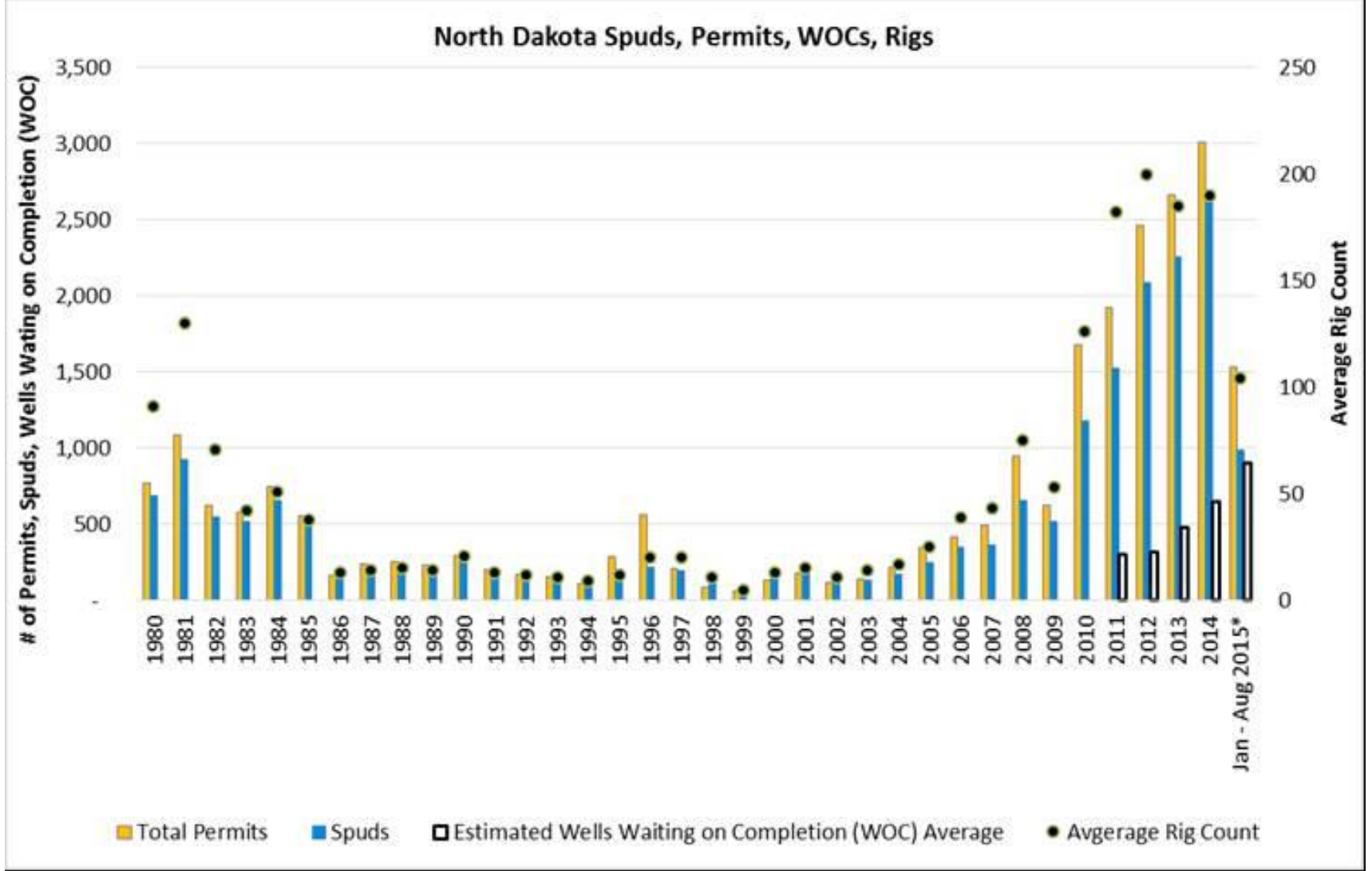

Source: North Dakota Industrial Commission data, Wells Waiting on Completion (WOC) number reflects January - August 2015 estimate using NDIC data (2011 figure reflects estimate 8-month estimate not 12)

\subsection{Concluding Summary}

Current production data reflects relative stability in the Bakken, but production declines are on the horizon and may perhaps be imminent. The rig count has been reduced by nearly two-thirds since January, and permit levels are considerably lower than 2014. The number of wells waiting on completion continues to rise month over month. Well performance has continued to impress, but this is a direct result of enhanced completions in core acreage positions. Bakken production is largely controlled by the top 10 producers; this lack of producer diversification will have an impact on future drilling activity levels and future production as many of these companies delegate capital to other assets which require drilling to hold acreage positions.

\section{The Permian Basin}

The Permian Basin is one of the oldest producing basins in the world, with production dating back to the early 1900s. It stretches across the southeast corner of New Mexico and a large swath of western Texas, encompassing hundreds of thousands of square miles and dozens of counties. Over 100,000 producing wells contribute to roughly $1.9 \mathrm{mbd}$ of oil production, a rise of nearly $500,000 \mathrm{~b} / \mathrm{d}$ since 2013. The growth story comes from both unconventional and conventional drilling techniques into stacked reservoirs including the Wolfcamp, Bone Springs, Trend Area (Spraberry area), and 

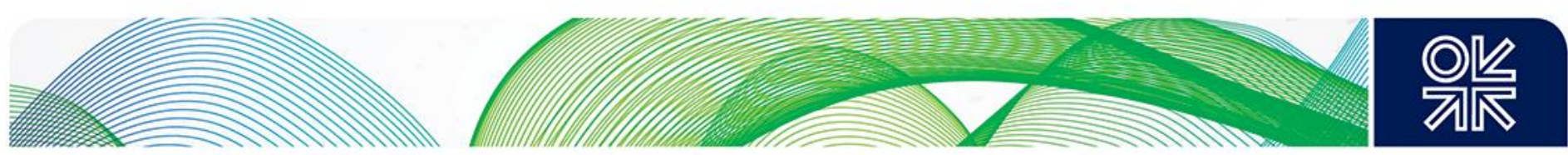

Spraberry reservoirs. The basin consists of multiple sub-basins; the most targeted are the Delaware and Midlands Basins. ${ }^{16}$ Until the recent price decline, over 200 vertical rigs (the majority of all vertical rigs in the US) were operating in the Permian Basin using traditional drilling methods to vertically target and frac into multiple stacked pay zones, primarily in the Midland Basin's Trend Area and Spraberry reservoirs. Horizontal production from the Delaware basin began in earnest in 2011, primarily in New Mexico. Horizontal drilling in the Texas portion of the Permian followed shortly thereafter with horizontal drilling in the Spraberry and Trend Area reservoirs, which were traditionally vertical targets.

The Permian Basin is currently the most resilient play in the face of lower oil prices. Despite the price decline, some companies have actually added rigs and are planning to increase production (as of early August 2015). This resiliency is due to several factors, including the level of development and infrastructure already in place. The last few years of Permian Basin drilling activity has been marked by an incredible acceleration in production growth and asset delineation, but it is still behind both the Bakken and Eagle Ford in terms of development. Many companies (including majors) secured acreage positions in recent years and are just now starting to test and drill their acreage. Permian Basin drilling activity accelerated over the course of 2014 as companies began to expand their presence and start aggressively de-risking acreage positions with supportive oil prices. The total rig count peaked in December 2014 at 568 rigs but has more than halved since ${ }^{17}$, taking a large bite out of US oil drilling activity.

\subsection{Production Overview}

Recent production data, as shown in Figure 14, indicates initial declines over the past couple of months in both New Mexico and Texas. Total Permian Basin production began to falter in February and March but recovered slightly, peaking in May 2015 at 1.936 mbd. Texas Permian production has declined by about $40,000 \mathrm{~b} / \mathrm{d}$ from May to July. New Mexico Permian production has dropped about $16,000 \mathrm{~b} / \mathrm{d}$ since May. Current Permian Basin production is $1.88 \mathrm{mbd}$. The figure below shows total Permian Basin production dating back to 2000. Production increases in both New Mexico and Texas are not notable until 2011 and 2012 respectively. This production is liquid production, but unlike the Bakken, which is strictly crude oil, some Permian production is lighter and would be considered condensate. These volumes are currently relatively small, however, and are estimated to be 100,000 $\mathrm{b} / \mathrm{d}$ to $200,000 \mathrm{~b} / \mathrm{d}$ at most.

\footnotetext{
${ }^{16}$ The Delaware Basin encompasses part of southern New Mexico and the northern portion of the western Texas panhandle. The Midland Basin is east of the Delaware Basin and only in Texas. See map from the Bureau of Economic Geology http://www.beg.utexas.edu/techrvw/wtgs-dutton/index.htm - Shirley P. Dutton, Mark H. Holtz, Thomas A. Tremblay, and Helena H. Zirczy, Bureau of Economic Geology, The University of Texas at Austin, Austin, Texas. ; See stratigraphic column from USGS http://certmapper.cr.usgs.gov/data/noga95/prov44/text/prov44.pdf - Mahlon M. Ball, 'Permian Basin Province'. 17233 rigs - Baker Hughes, 16 October 2015
} 

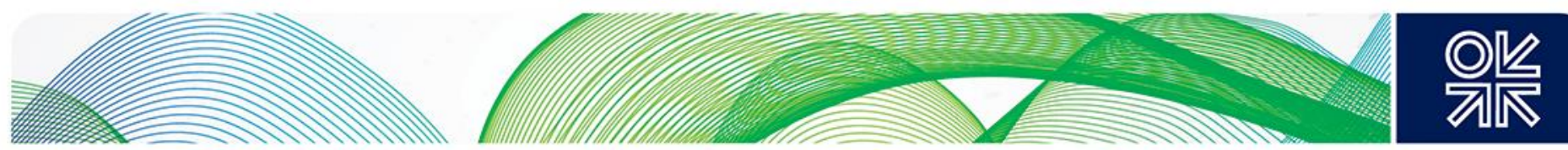

Figure 14: Permian Basin Production by State, b/d

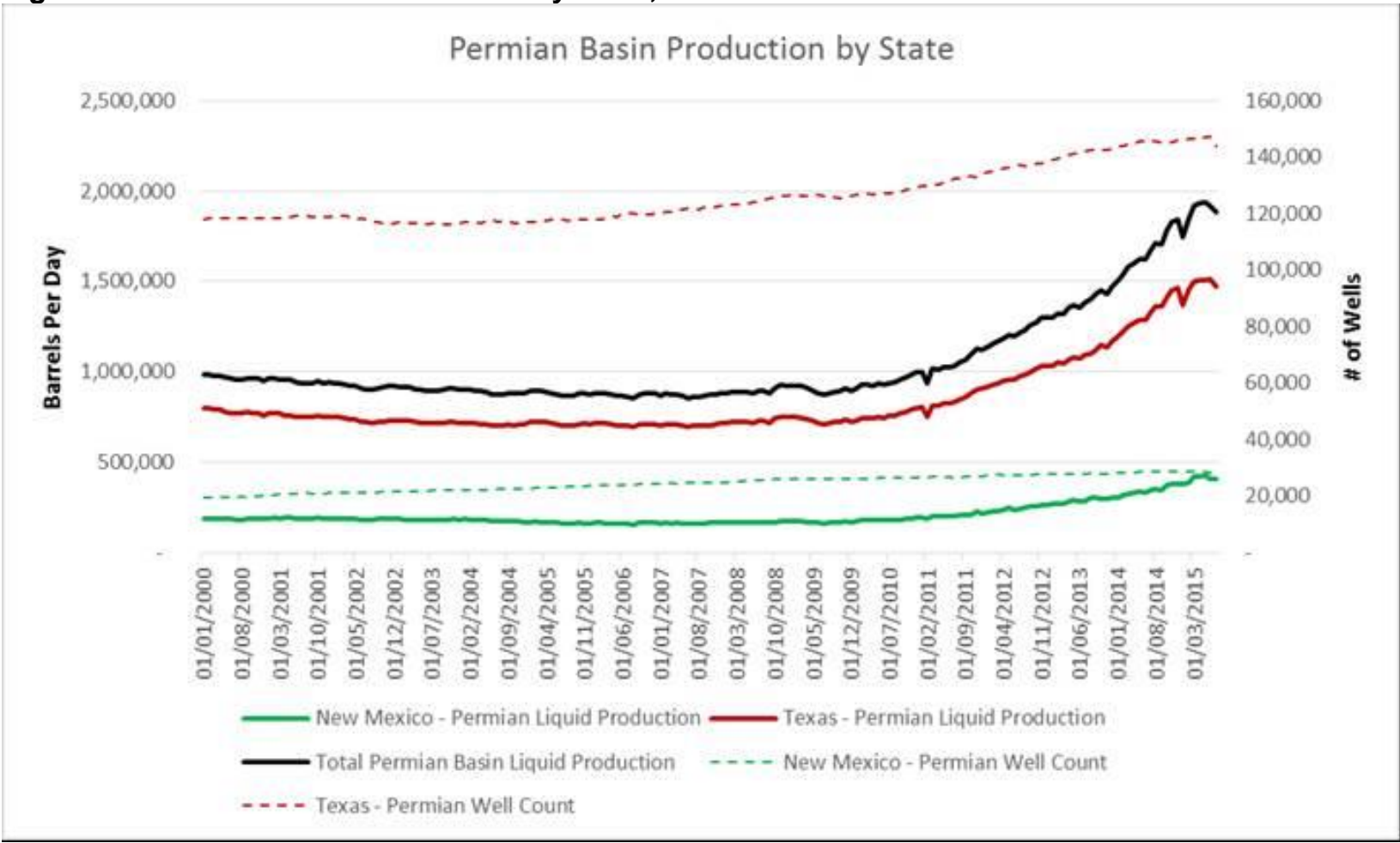

Source: DrillingInfo data (14 October 2015)

While overall Permian Basin production has remained resilient, production data lags by two to three months. ${ }^{18}$ The latest full month of production data for the Permian Basin is from July 2015. Assuming a 90-day lag for well completions, the rig count contributing to July's 2015 production figure is actually April's oil rig count of 259 , higher than the July average of 240 . When it becomes available, additional production data will most likely show further production declines, reflecting the sharply reduced rig fleet. Table 3 below illustrates the rig count and production alignment with an estimated 90-day completion lag.

\footnotetext{
${ }^{18}$ Texas data lags two months whereas New Mexico typically data lags three months, so total Permian Basin production data usually lags by roughly three months.
} 

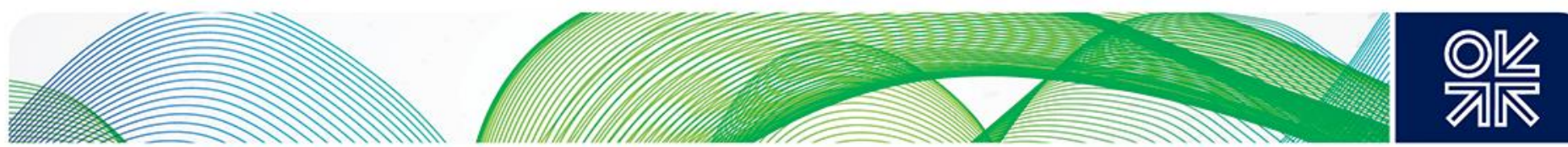

Table 3: Permian Basin Liquid Production and Rig Count

\begin{tabular}{|c|c|c|c|}
\hline $\begin{array}{l}\text { Month - Oil } \\
\text { Production }\end{array}$ & $\begin{array}{l}\text { Permian Basin } \\
\text { Liquid (mostly oil) } \\
\text { Production b/d }\end{array}$ & Month - Rig & $\begin{array}{l}\text { Permian } \\
\text { Basin Oil Rig } \\
\text { Count }\end{array}$ \\
\hline Jan-14 & $1,507,443$ & Oct-13 & 441 \\
\hline Feb-14 & $1,540,910$ & Nov-13 & 457 \\
\hline Mar-14 & $1,579,278$ & Dec-13 & 465 \\
\hline Apr-14 & $1,604,451$ & Jan-14 & 467 \\
\hline May-14 & $1,621,509$ & Feb-14 & 483 \\
\hline Jun-14 & $1,623,039$ & Mar-14 & 510 \\
\hline Jul-14 & $1,672,907$ & Apr-14 & 531 \\
\hline Aug-14 & $1,710,436$ & May-14 & 540 \\
\hline Sep-14 & $1,705,935$ & Jun-14 & 547 \\
\hline Oct-14 & $1,783,828$ & Jul-14 & 553 \\
\hline Nov-14 & $1,830,103$ & Aug-14 & 554 \\
\hline Dec-14 & $1,845,135$ & Sep-14 & 557 \\
\hline Jan-15 & $1,930,516$ & Oct-14 & 485 \\
\hline Feb-15 & $1,750,057$ & Nov-14 & 558 \\
\hline Mar-15 & $1,847,911$ & Dec-14 & 560 \\
\hline Apr-15 & $1,917,771$ & Jan-15 & 540 \\
\hline May-15 & $1,935,738$ & Feb-15 & 372 \\
\hline Jun-15 & $1,920,487$ & Mar-15 & 300 \\
\hline Jul-15 & $1,881,423$ & Apr-15 & 259 \\
\hline Aug-15 & & May-15 & 233 \\
\hline Sep-15 & & Jun-15 & 231 \\
\hline Oct-15 & & Jul-15 & 240 \\
\hline Nov-15 & & Aug-15 & 251 \\
\hline Dec-15 & & Sep-15 & 249 \\
\hline Jan-16 & & Oct-15 & \\
\hline
\end{tabular}

Source: DrillingInfo production data, Baker Hughes oil rig count

New Mexico and Texas Horizontal and Vertical Production Breakdown ${ }^{19}$

Horizontal drilling in New Mexico marked the beginning of unconventional oil drilling activity in the Permian Basin, initially via targeting of the Bone Springs formation. Figure 15 below illustrates rapid production growth from 2008 onwards and a steadily rising well count ${ }^{20}$; production only began to decline in the past two months. New Mexico horizontal well production is currently $278,000 \mathrm{~b} / \mathrm{d}$, down slightly from a peak of $288,000 \mathrm{~b} / \mathrm{d}$ in May. ${ }^{21}$

\footnotetext{
${ }^{19}$ Unlike the Bakken and Eagle Ford, a vast amount of historical production data is included in Permian Basin liquid production figures, including conventional drilling methods like vertical drilling into tight/unconventional formations. Extensive water flooding also takes place in the Permian Basin to enhance production from older vertical wells.

${ }^{20}$ The rise in production but drop in well count is likely due to data lags. Latest production data and well figures are often revised in the following months as data is further updated.

${ }^{21}$ Production has moved slightly up and down in the past couple of months. This likely reflects continual changes in the rig fleet by operators as well as errors in production data which will may be revised in the coming months as additional well data comes in.
} 

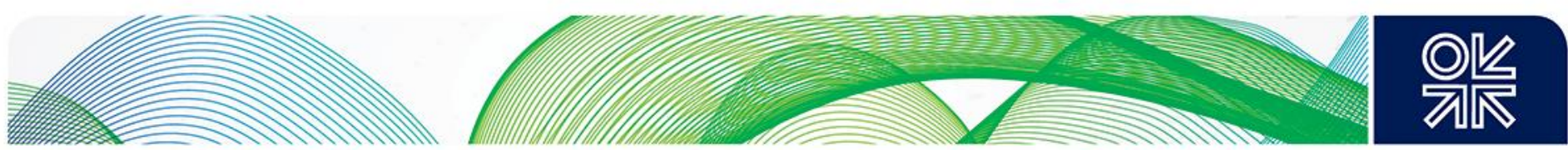

Figure 15: New Mexico: Horizontal-Permian Basin Production and Number of Wells

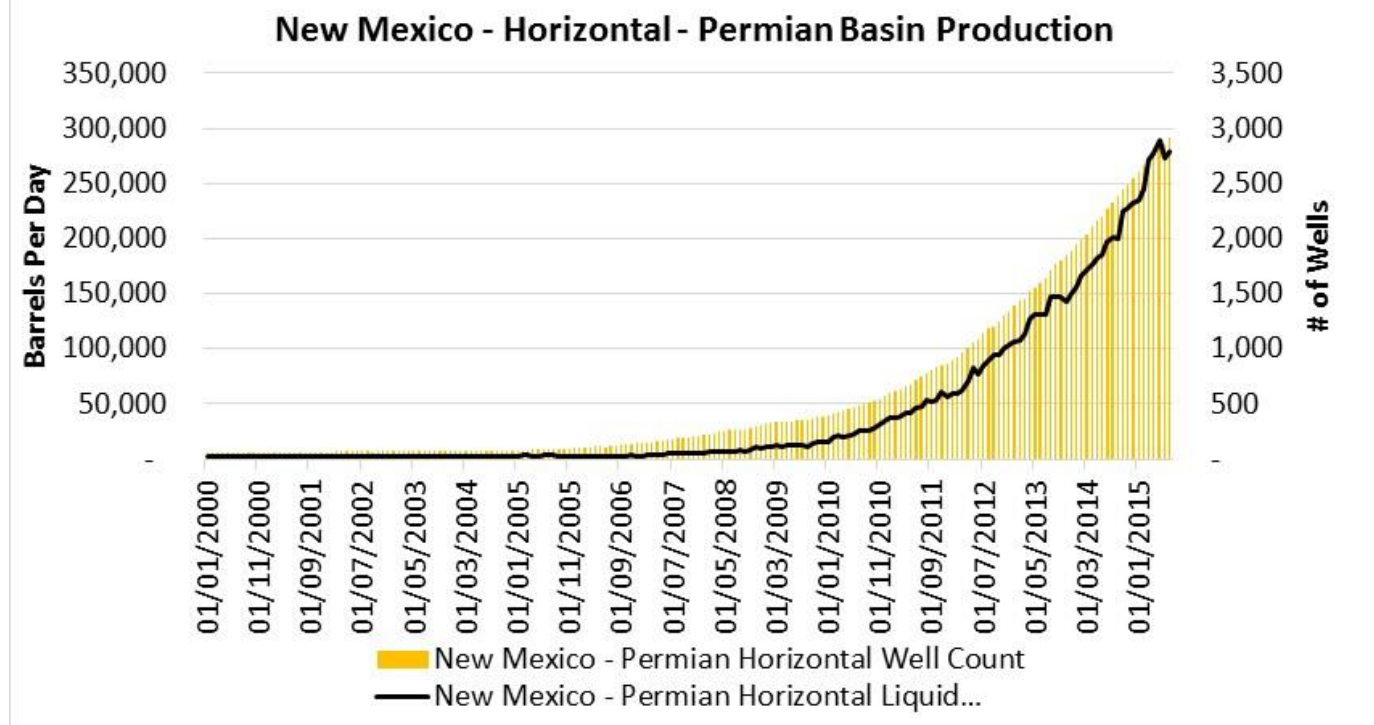

Source: Drilling Info (14 October 2015)

New Mexico vertical well production accounts for roughly $27,000 \mathrm{~b} / \mathrm{d}$ of liquid production as of July 2015. Production has remained in the $30,000 \mathrm{~b} / \mathrm{d}$ range since late 2012 despite gradual well additions. As Figure 16 below indicates, vertical drilling on the New Mexico side of the Permian basin stepped up in late 2010. Vertical production has declined by about 5,000 b/d since December 2014.

Figure 16: New Mexico: Vertical, Permian Basin Production and Number of Wells

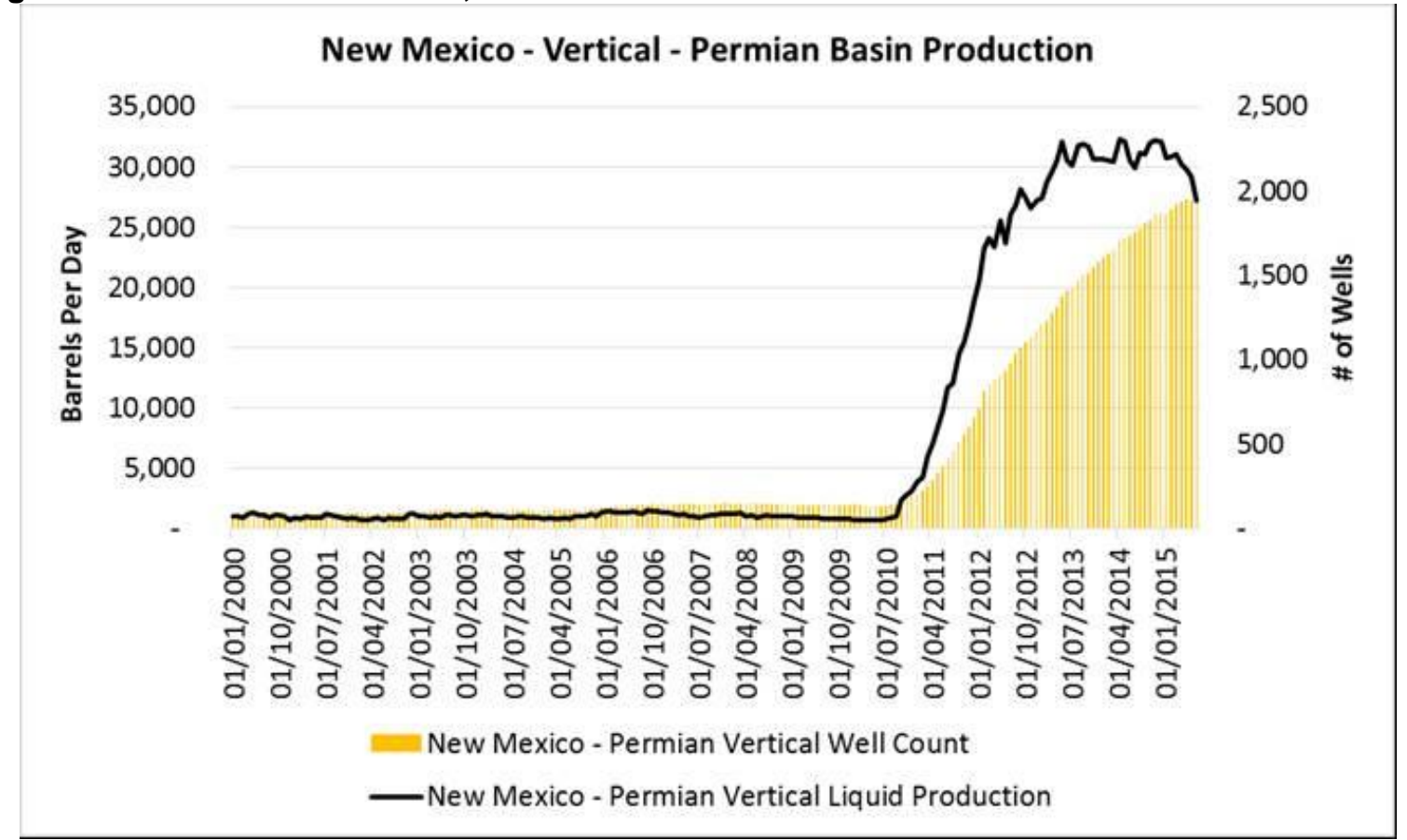

Source: Drilling Info (14 October 2015) 

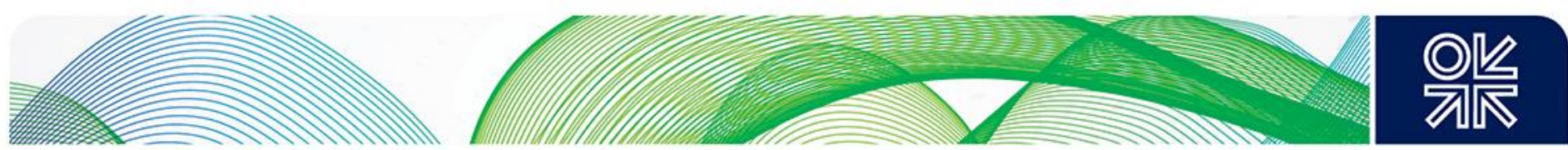

Vertical well production on the Texas side of the Permian Basin contributes almost $750,000 \mathrm{~b} / \mathrm{d}$ to the basin's total production. Over 10,000 vertical wells have been added since the end of 2009.22 Texas likely saw a larger increase in vertical drilling activity than New Mexico because the formations were better understood in the Midland Basin and the historical Spraberry region (lots of old vertical well logs exist for data analysis). Vertical drilling also opened the door for smaller independent oil companies. A new vertical well may only produce a $100 \mathrm{~b} / \mathrm{d}$ or less in the first month, but it costs a fraction of what a horizontal well costs (an estimated \$1-2 million per vertical well compared to several million for a horizontal well). In the last few months, production has fluctuated and decreased, indicating lower oil prices are having an impact on smaller producers and overall activity. Producers are also conscious of cash flow and may have reduced vertical drilling in favor of focusing capital on horizontal drilling in order to achieve larger increases in production. Current production (July 2015) for Texas vertical Permian Basin wells is $749,000 \mathrm{~b} / \mathrm{d}$, a decrease of about $30,000 \mathrm{~b} / \mathrm{d}$ month over month from June 2015. ${ }^{23}$ This is a 91,000 b/d production decline from December 2014.

Figure 17: Texas-Vertcial-Permian Basin Production (b/d)

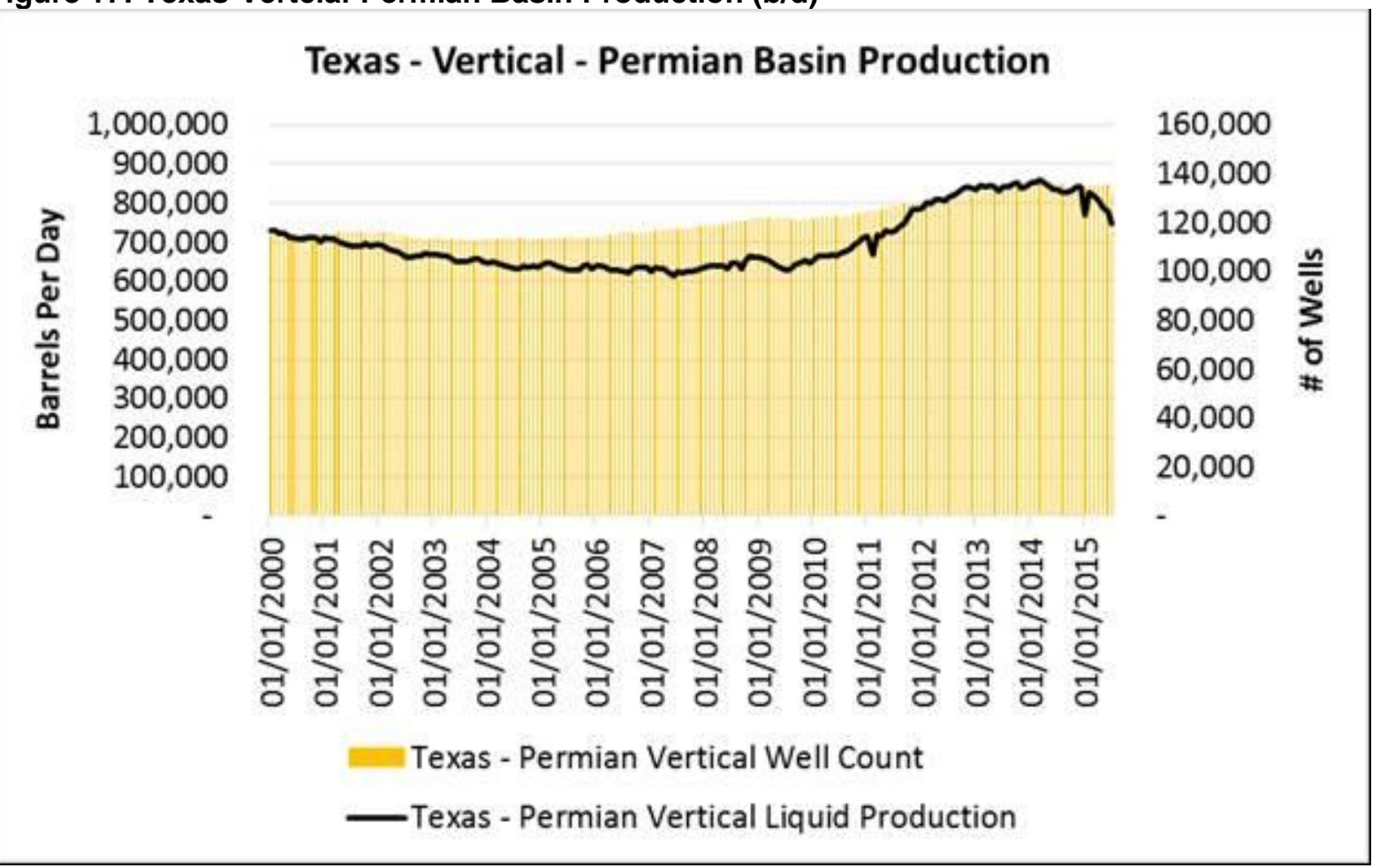

Source: Drilling Info (14 October 2015)

The growth in oil production from horizontal wells in the Texas portion of the Permian Basin accounts for a large portion of total Permian Basin production growth. This production grew from only 70,000 $\mathrm{b} / \mathrm{d}$ in mid-2011 to almost $680,000 \mathrm{~b} / \mathrm{d}$ by June 2015 . While this amount is over double that of New Mexico's horizontal well contribution, the performance of New Mexico's wells is still better. This is due

\footnotetext{
22 This is not necessarily total new wells as some wells may have been removed from production and others may have been added.

${ }^{23}$ These recent production and corresponding well drops could be revised in August's data (higher or lower), but they illustrate a distinctive drop in production regardless.
} 

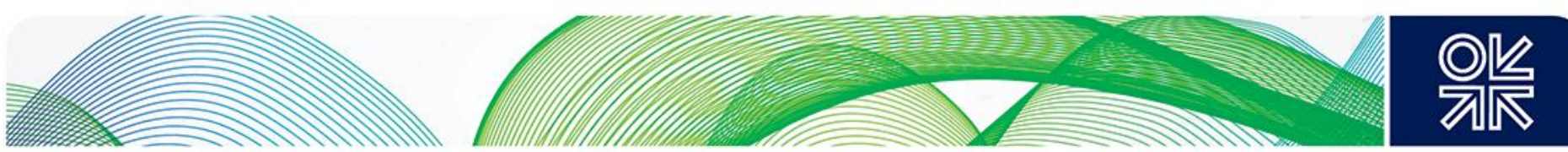

in part to the presence of lower-pressure wells in the Midland Basin. ${ }^{24}$ Texas horizontal production has barely begun to decline, showing a slight $10,500 \mathrm{~b} / \mathrm{d}$ drop from June to July (July production is about $669,000 \mathrm{~b} / \mathrm{d}$ compared to $679,000 \mathrm{~b} / \mathrm{d}$ in June).

Figure 18: Texas: Horizontal-Permian Basin Production and Number of Wells

Texas - Horizontal - Permian Basin Production

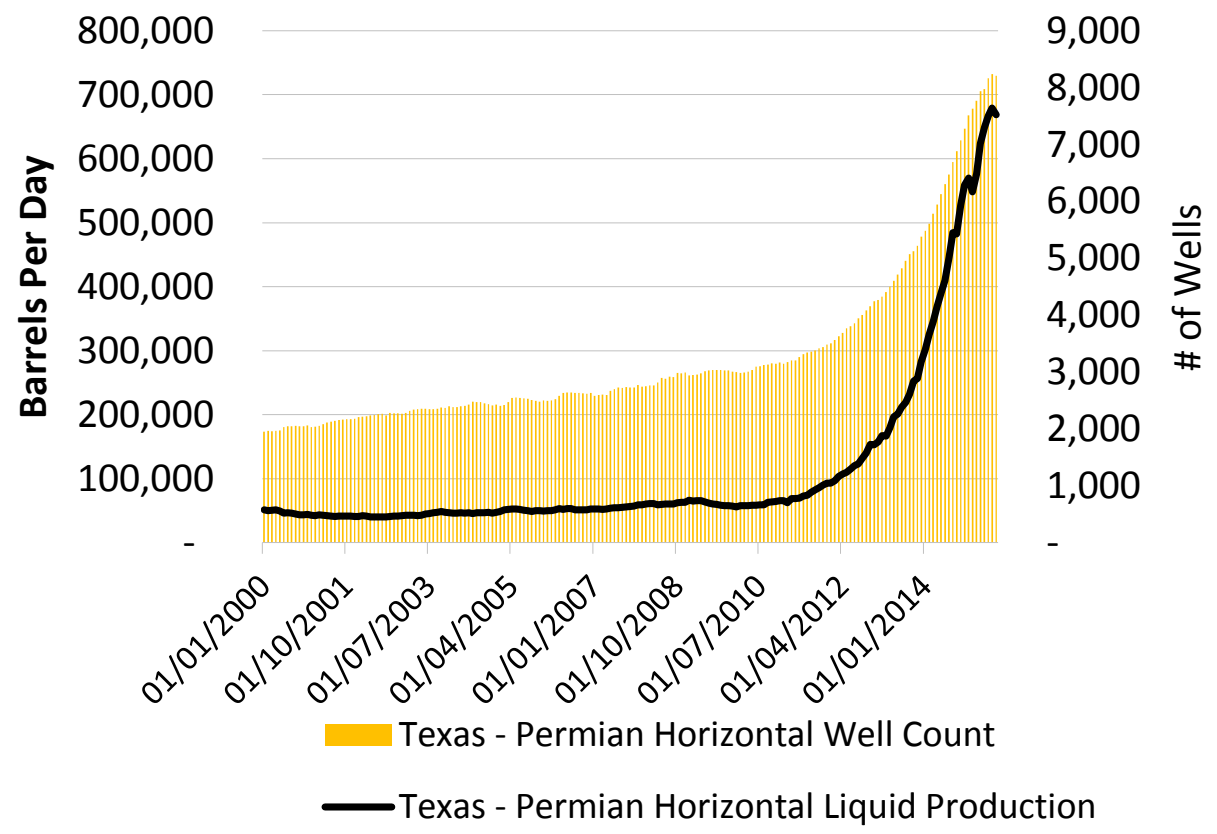

Source: Drilling Info (14 October 2015)

\subsection{Permian Basin Production and Top Producers}

Due to the immense size of the Permian Basin and the potential that lies in each sub-basin, the Permian's producer profile is far more diverse than many other oil plays. The top 10 producers currently account for about $1 \mathrm{mbd}$ of production, while all other producers account for approximately $900,000 \mathrm{~b} / \mathrm{d}$ (see Figure 19). In this sense, the Permian Basin is one of the less consolidated unconventional oil plays.

\footnotetext{
${ }^{24}$ The Midland Basin has a vast amount of historical production. Old vertical wells can make it tricky to land new vertical and horizontal wells given that drainage has already occurred in the reservoir. Lower pressure can result in lower production rates. Some have attributed new lower pressure wells to old production which has reduced the reservoir pressure over time; however, there is evidence that the Midland Basin has specific areas that have always had lower pressure.
} 

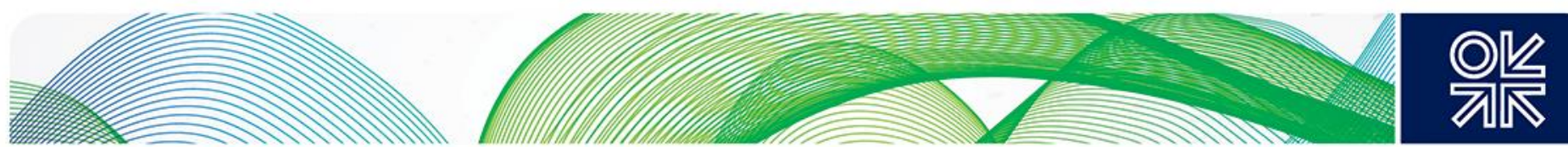

Figure 19: Production Allocation by Top 10 Producers

\section{Production Allocation by Top 10 Producers}

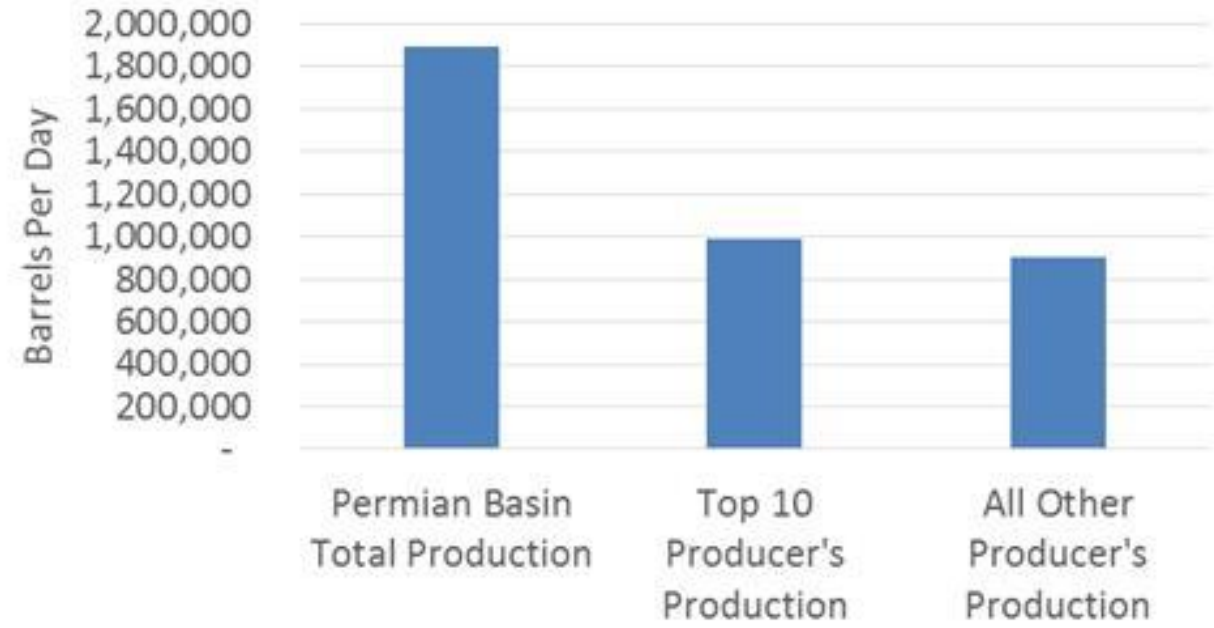

Source: Production data provided by PetroNerds and given to EPRINC (October 2015)

As of 16 October 2015, the top 10 producers were currently operating 93 of 224 total rigs running in the Permian (see Figure 20). A total of 69 other companies were drilling in the Permian with the remaining 131 rigs. ${ }^{25}$ This producer diversification is a factor contributing to production and drilling activity resiliency despite low oil prices.

Figure 20: Rig Allocation by Top Prodcuers

\section{Rig Allocation by Top Producers}
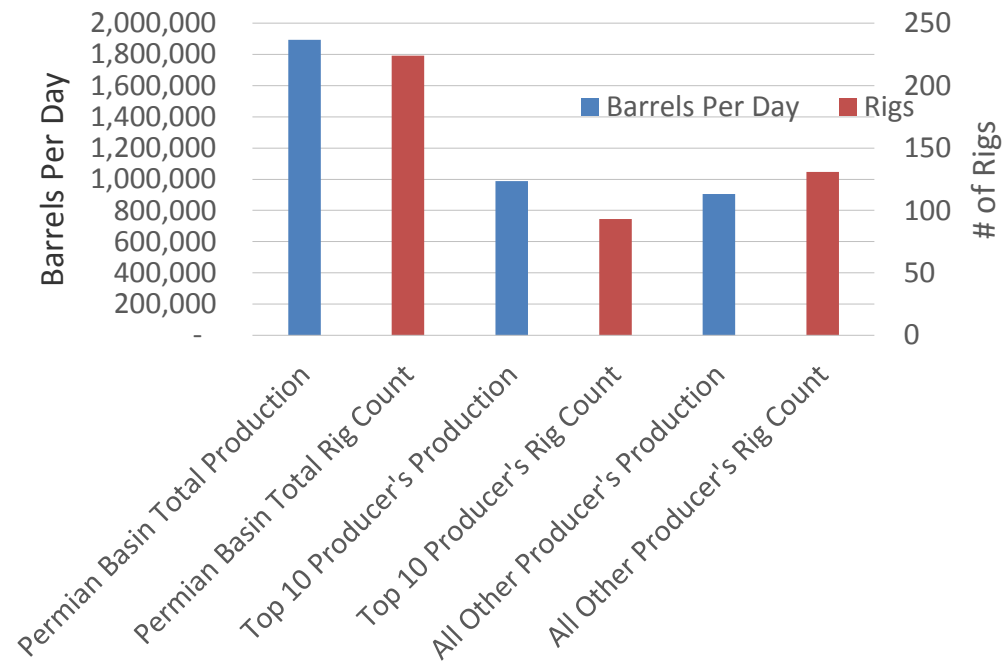

Source: Production data provided by PetroNerds and given to EPRINC (October 2015), DrillingInfo rig data (16 October 2015)

\footnotetext{
${ }^{25}$ There may be less than 60 operating companies, given that some have multiple subsidiaries.
} 

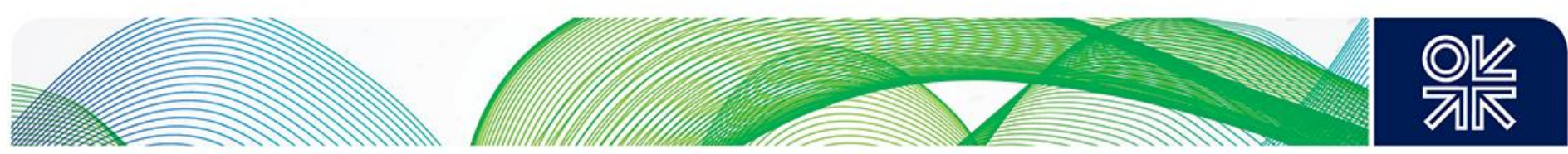

\title{
4.3 Permian In-Depth
}

For some of the top producers, the Permian Basin represents their oiliest asset. This means other more condensate or natural gas liquid (NGL) rich assets are being pushed aside in favor of the Permian Basin, which typically yields 70 to 80 per cent oil on most wells (but varies by region). Continued testing and asset delineation is also taking place as companies seek to better understand future production potential and look to book increases in reserves.

As noted earlier, the Permian is behind its peers in the Bakken and Eagle Ford in terms of outright unconventional development. Due to the sheer size and depth of the play, different operators are in different stages of development. As the unconventional potential of the Permian is still in the very early stages of evaluation, the rig count actually increased by two dozen over the summer (from the end of June to mid-August). ${ }^{26}$ This has helped contribute to the Permian Basin's relative resiliency in comparison to the Bakken and Eagle Ford.

'Enhanced completions' and 'high-density completions' were two common phrases again echoed by Permian operators in recent second-quarter earnings calls and statements. As in the Bakken, some producers are seeing success by adding more sand per lateral foot. As companies better understand their assets, they are becoming more comfortable placing wellbores closer together. High-density completions are certainly improving efficiencies. Companies are advertising that they are now in 'development mode' in the Permian and emphasizing that they can now capitalize on some of their asset delineations from recent years. Direct quotes from company conference calls best characterize operator optimism and the role of asset delineation in the Permian Basin:

\begin{abstract}
...we've used our vast database to update our basin hydrocarbon richness map and to build the petrophysical and geochemical models necessary to improve well performance and to add more locations to our inventory. Second, our teams have further reduced our drilling and completion costs and optimized the value of a manufacturing approach in our key areas. In the fourth quarter of last year, we began transitioning from appraisal mode to a targeted development program, utilizing a manufacturing approach combined with integrated planning and engineering. This has reduced nonproductive time, maximized the efficiencies of pad drilling, including the use of zipper fracs, and has reduced infrastructure costs. As a result of these efforts, we have achieved significantly improved well delivery and lower well cost.
\end{abstract}

\section{Oxy, second-quarter earnings/conference call, Seeking Alpha}

\begin{abstract}
A benefit of our scale in the Permian is our ability to transfer success from one asset to another. We've shortened the learning curve in the Southern Delaware with drilling days down compared to a year ago. In addition to drilling faster we're realizing completion improvements and optimizing well spacing...we're also running two rigs in the Midland basin, focusing on long lateral development and delineating the multi-zone Wolfcamp and Spraberry across our position. Our Midland basin assets are primarily held by production, which provides operational flexibility as we refine our drilling completion methods to effectively recover more oil.
\end{abstract}

\section{Concho Resources, second-quarter earnings/conference call, Seeking Alpha}

Regarding strong well performance results in multiple Wolfcamp benches and the Spraberry shale, one company noted:

\footnotetext{
${ }^{26}$ The rig count has since dropped to 233 in mid-October from 255 in mid-August.
} 

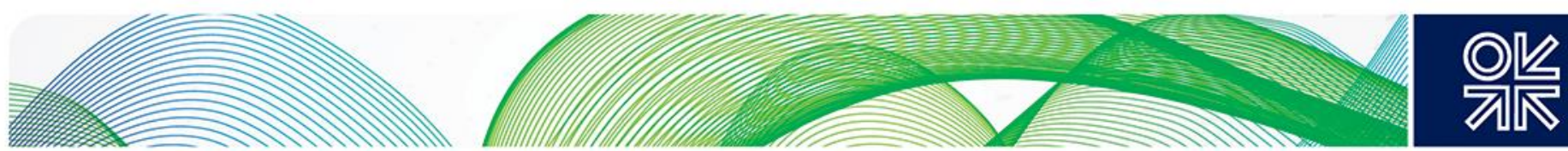

Both statistics, as many have already remarked in notes that were out this morning, are significant improvements over our previously reported results and have been driven by continuous improvements in our completion design, carefully targeted landing zones, and by improvements in our artificial lift design for early well production performance. During the second quarter we began moving our Permian operations to pad development mode. The reasons behind this move are two-fold. First, pad-development greatly reduces the downtime from offset well fracs as we can now batch complete new wells. And second, drilling and completion costs are reduced significantly due to the efficiencies that are inherent in pad development operations.

\section{QEP, second-quarter earnings/conference call, Seeking Alpha}

\subsection{Recent Activity and Well Performance}

The Permian's producer diversification, combined with cutbacks in other plays, has been supportive of activity in 2015. Figure 21 below shows all wells brought online from January 2015 onwards, categorized by horizontal and vertical well types (this does include some gas wells). Many of the wells brought onto production in 2015 have been horizontal wells, supporting company claims that development mode is underway and that more aggressive production growth is desired, perhaps to offset slowdowns elsewhere. This follows the trend of the past two years, in which horizontal wells represent an increasing share of wells drilled. While there is not one clear 'core' area in the Permian, the wells brought online in 2015 have largely been in the Delaware Basin and Midland Basin.

\section{Figure 21: Wells brought online from January 2015 onwards in Permian Basin}

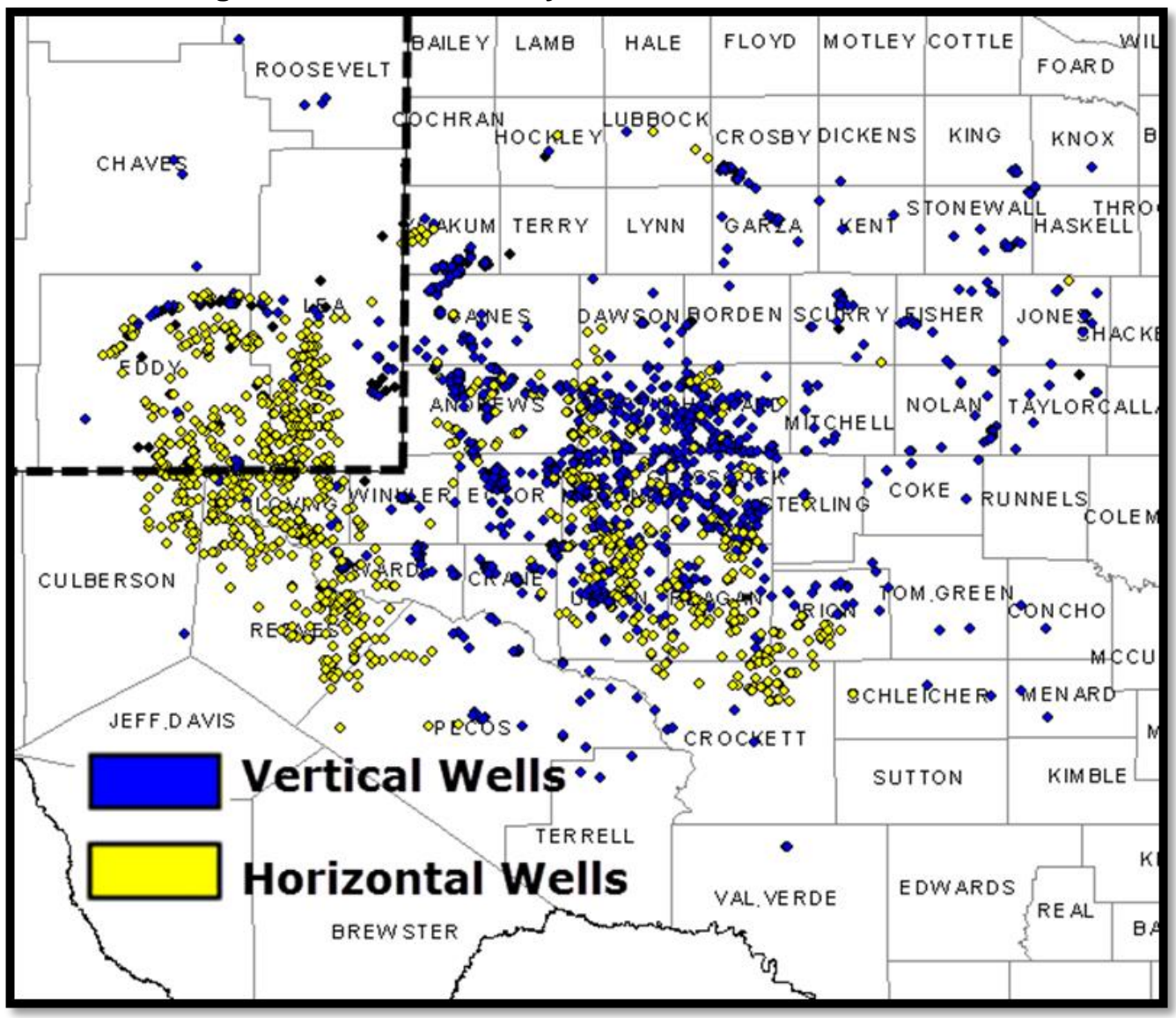

Source: Drillinglnfo, All wells brought onto first production starting 1 January 2015 (15 October 2015)

Individual well performance in the Permian Basin is not as strong as the Bakken, but it has been improving. Continuing increases in both initial production rates and in the shape of the decline curve 

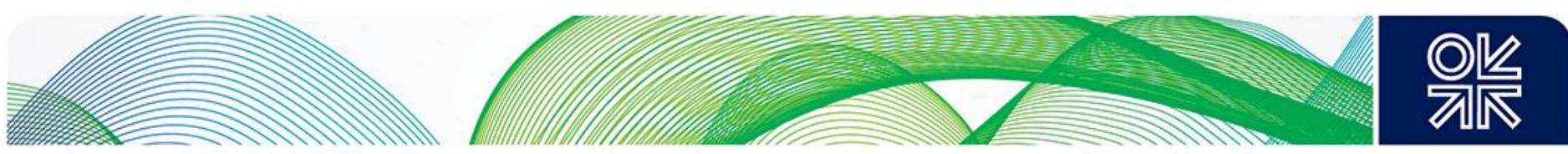

suggest that companies have a better grasp of individual formations and are getting more oil out of them. It will take time before the medium and long-term impacts of completion design changes and other efficiencies are understood. The average initial production rate for horizontal wells in New Mexico has risen every year for each of the past five years. Horizontal New Mexico (NM) wells outperform Texas horizontal wells by $100 \mathrm{~b} / \mathrm{d}$ on average, as indicated in the initial production rate graph below. The average NM horizontal IP rate for 2015 is $494 \mathrm{~b} / \mathrm{d}$ - some $57 \mathrm{~b} / \mathrm{d}$ higher than 2014, but lower than the IP rate increase of $77 \mathrm{~b} / \mathrm{d}$ from 2013 to 2014 (see Figure 22).

\section{Figure 22: Permian Basin Initial Production Rates (b/d)}

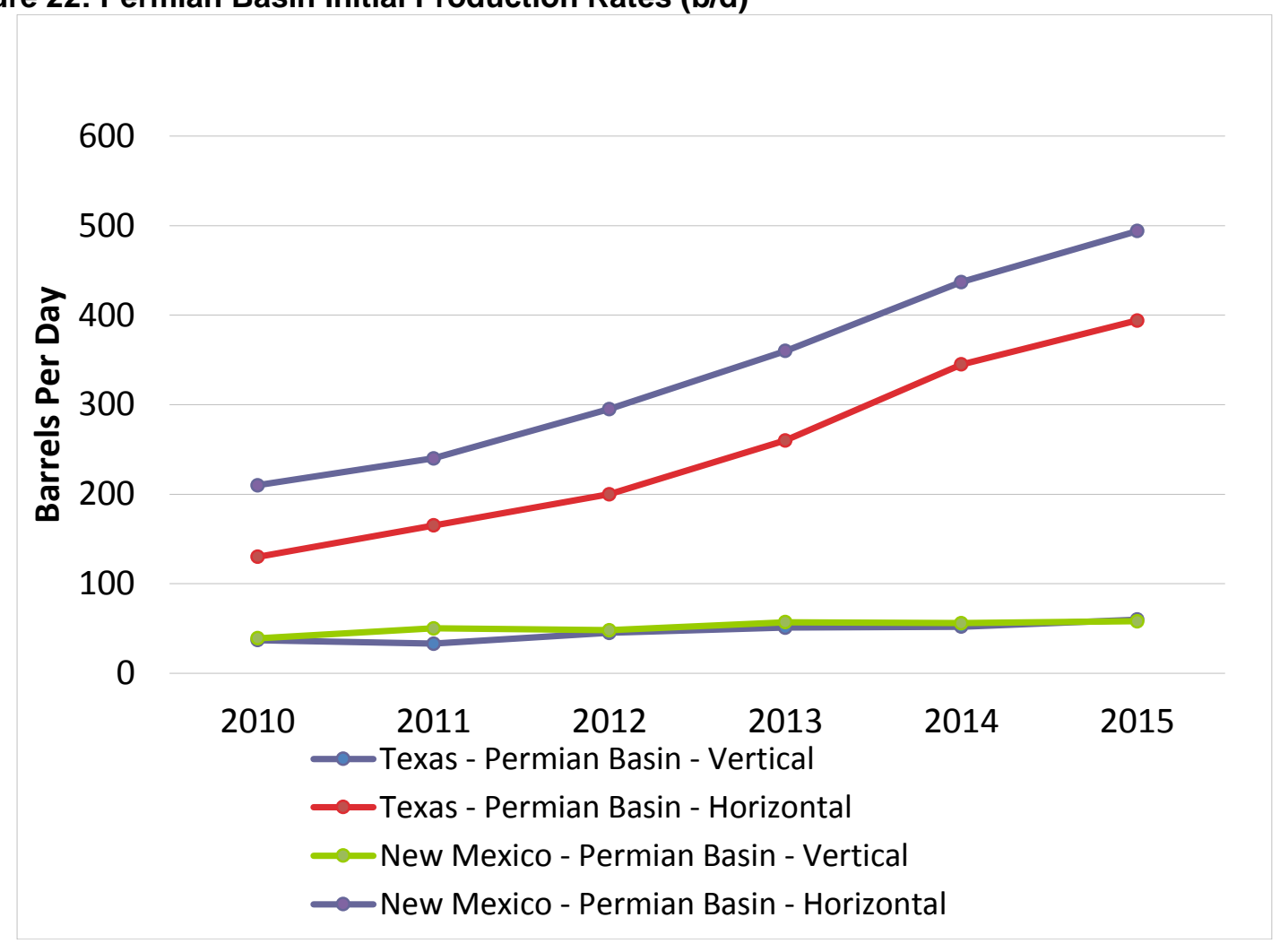

Source: DrillingInfo data and EPRINC estimates (14 October 2015)

Most importantly, however, the entire decline curve has also shifted upwards each year, meaning cumulative oil production per well is improving. ${ }^{27}$ Figure 23 below shows decline curves for horizontal New Mexico Permian Basin wells from 2012.

\footnotetext{
${ }^{27}$ Upward movement in the decline curve, as indicated in the Figures shown, means that the overall shape is moving upward and higher volumes of production over the life of the well are being achieved than in previous years.
} 

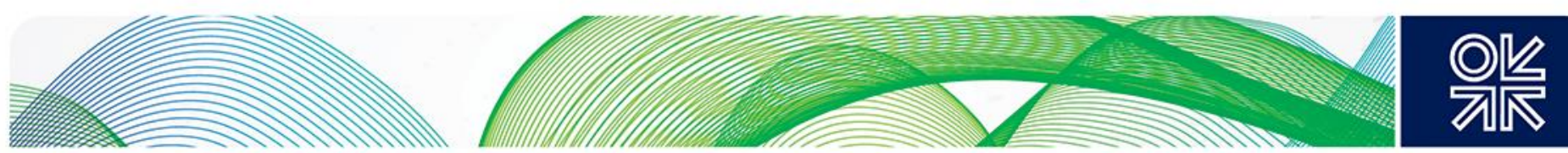

Figure 23: New Mexico: Horizontal Permian Basic Production Type/Decline Curve

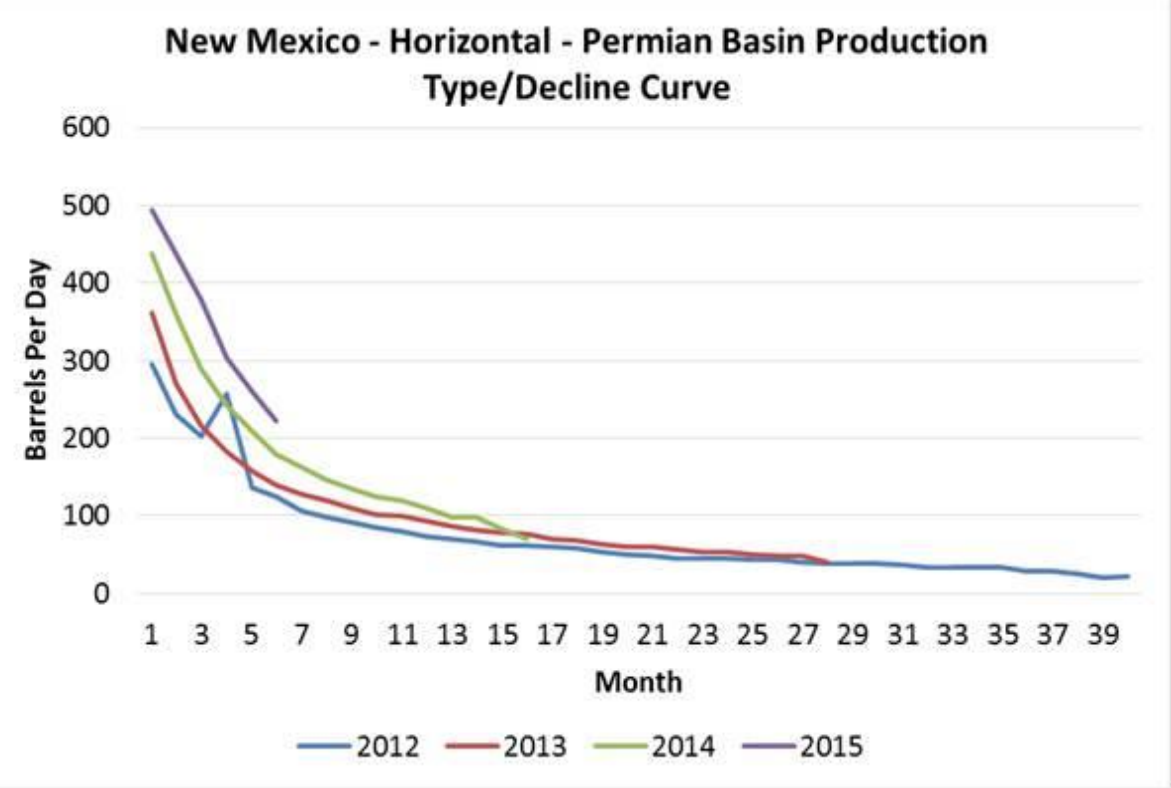

Source: DrillingInfo data and EPRINC estimates (14 October 2015)

Horizontal IP rates in the Texas portion of the Permian have also improved for the past five years (see Figure 24 below). The average $2015 \mathrm{IP}$ rate of $394 \mathrm{~b} / \mathrm{d}$ is $49 \mathrm{~b} / \mathrm{d}$ higher than 2014 but substantially lower than the $85 \mathrm{~b} / \mathrm{d}$ IP increase from 2013 to 2014 (this number represents a seven-month average - January to July 2015). This is likely due to declining activity levels in the face of lower oil prices: remember that 2014 marked a high point for Permian Basin drilling activity. However, the decline curve and recovery rates have also risen in Texas, resulting in substantial well performance increases in 2014, as shown in the graph below. Additional production data will be needed to see if the full decline curve for 2015 outperforms that of $2014 .^{28}$

Figure 24: Texas: Horizontal Permian Basin Production Type/Decline Curves

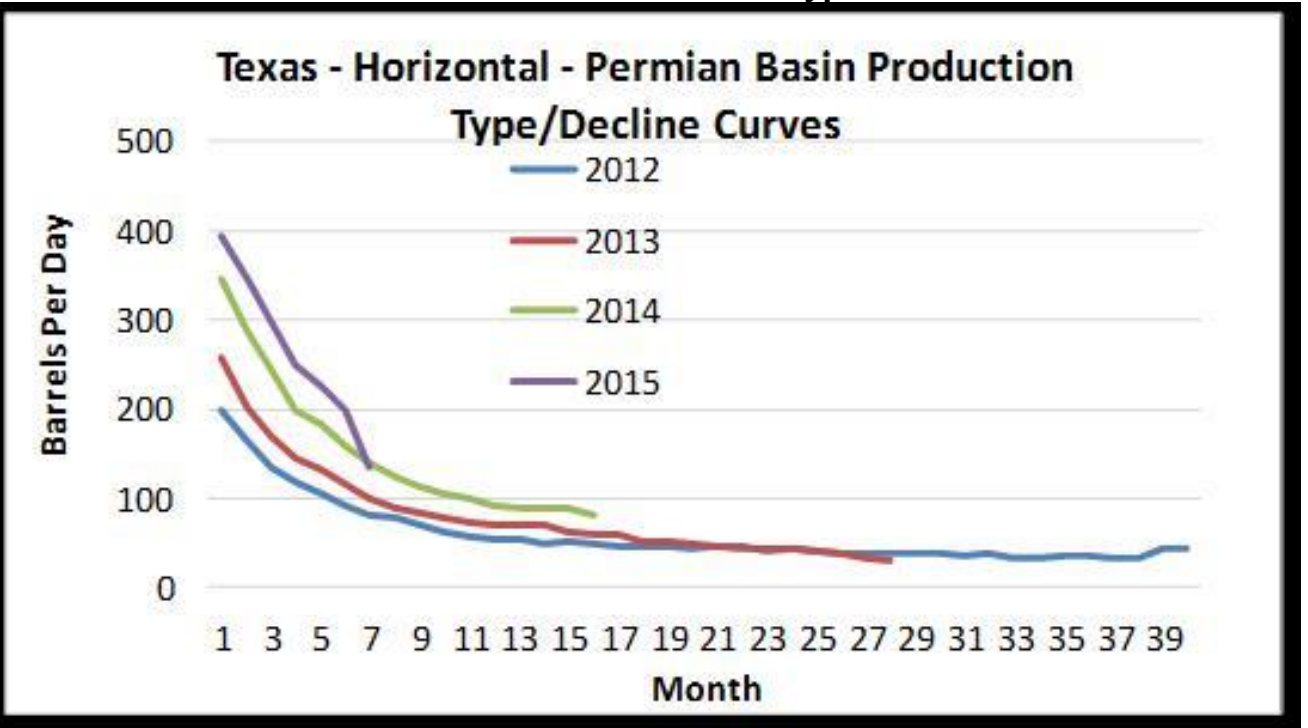

Source: DrillingInfo data and EPRINC estimates (14 October 2015)

\footnotetext{
${ }^{28}$ The slight drop in the latest monthly figure for 2015 will likely be revised in coming months as additional data is collected.
} 

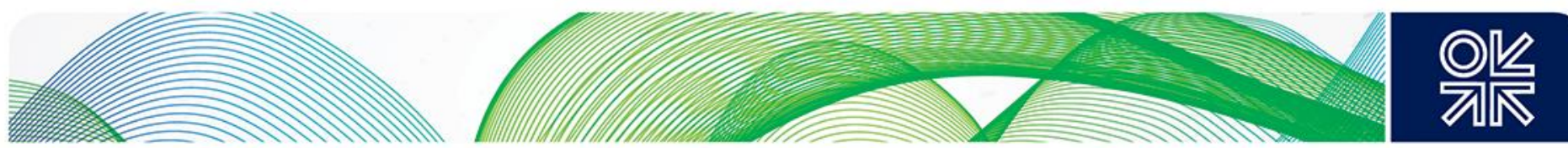

Vertical well performance in both Texas and New Mexico has remained relatively flat for almost five years. The 2015 decline rate, however, is showing slight improvement over 2014 and 2013.

Figure 25: Texas and New Mexico: Vertical Permian Basin Production Type/Decline Curves

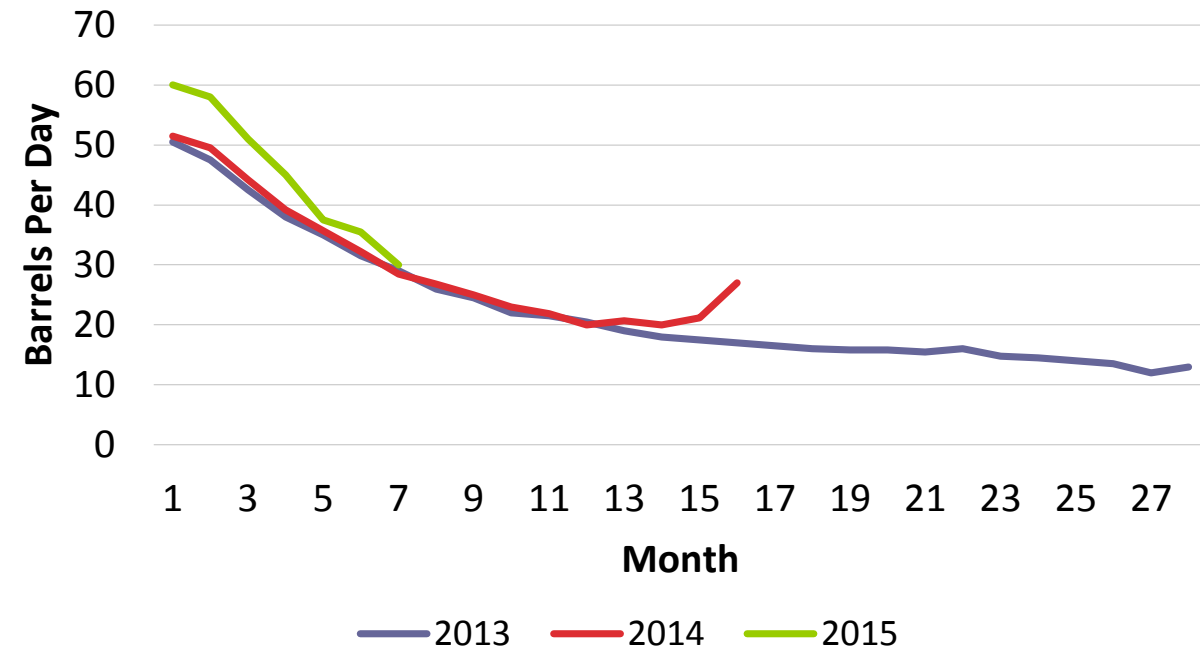

Source: DrillingInfo data and EPRINC estimates (14 October 2015)

\subsection{Permits and Rig Count}

Texas Permian drilling permit volumes are a fraction of what they were last year, and the total rig count has more than halved - from a peak of 568 in early December 2014 to a current count of just 233, seen in Figure 26 below (16 October 2015) ${ }^{29}$. By the end of December 2014, the horizontal rig count hit a peak of 353 before beginning to decline, dropping to 168 at the end June 2015, a loss of 185 rigs. Since the end of June, the horizontal rig count rose and peaked at 198 but has since fallen to 183 as of mid-October. Vertical drilling activity was already declining prior to the collapse in oil prices as producers gradually shifted from vertical to horizontal rigs. The price drop triggered further reductions in vertical drilling, with the number of vertical rigs declining from 201 at the beginning of December 2014 to 145 by January 2015. The amount of vertical drilling rigs in the Permian plateaued in the 50s over the summer before steadily declining in the last several weeks to 46 (16 October 2015).

\footnotetext{
${ }^{29}$ Baker Hughes rig count which is slightly higher than Drillinglnfo's rig count of 224 total rigs, both include dry gas rigs.
} 

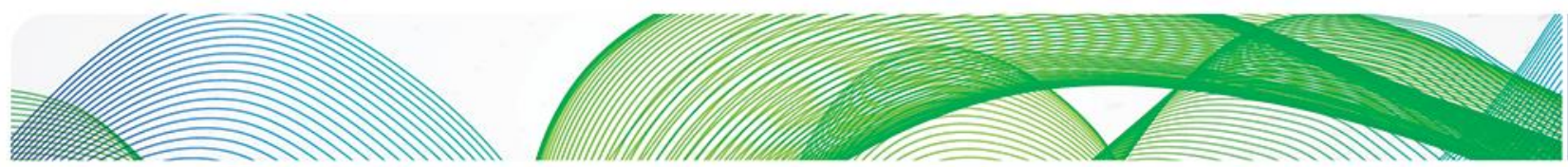

Figure 26: Permian Basin Rig Count by Drill Type

\section{Permian Basin Rig Count by Drill Type}

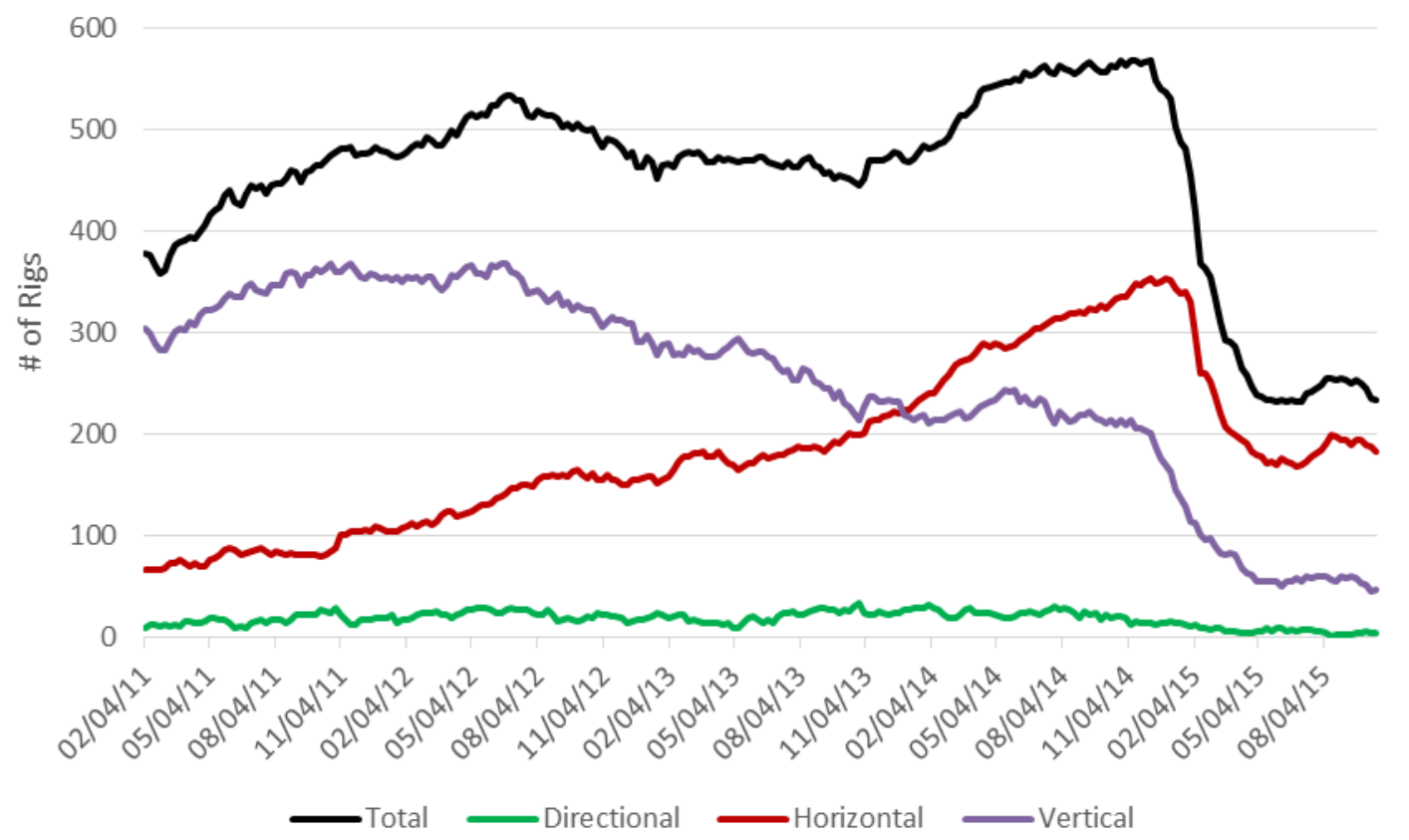

Source: Baker Hughes

Recent permit activity indicates a relative concentration of activity in the Delaware and Midland basins, as well as a focus on horizontal over vertical drilling. On 16 October 2015, the current number of permits filed in the previous 90 days was 2,255 - down slightly from 2,599 in mid-February 2015. ${ }^{30}$ Texas-only permit data for the Permian Basin shows a steep drop in new drilling activity for the first nine months of 2015 compared to 2014: new drill and re-entry permits from the Texas Railroad Commission totaled 3,341 compared to full-year filings of almost 11,000 the year before. If this current nine-month average were doubled, it would still be less than half of the permits filed in 2014. The number of wells estimated to be waiting on completion for the entire Permian Basin (Texas and New Mexico) is likely around $1,800 .{ }^{31}$

\footnotetext{
${ }^{30}$ DrillingInfo permit data.

${ }^{31}$ EPRINC estimate.
} 

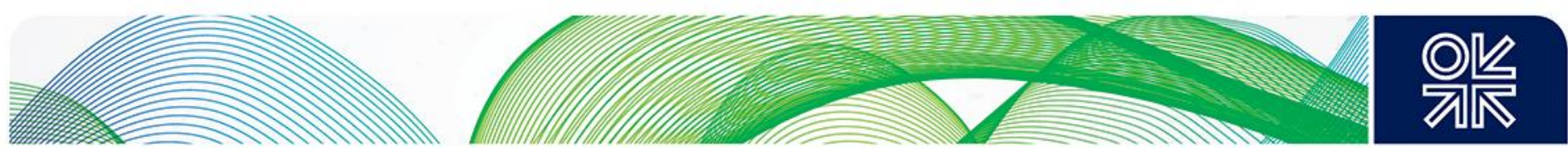

Figure 27: Texas Only Permian Permits (New Drill and Re-Entry)

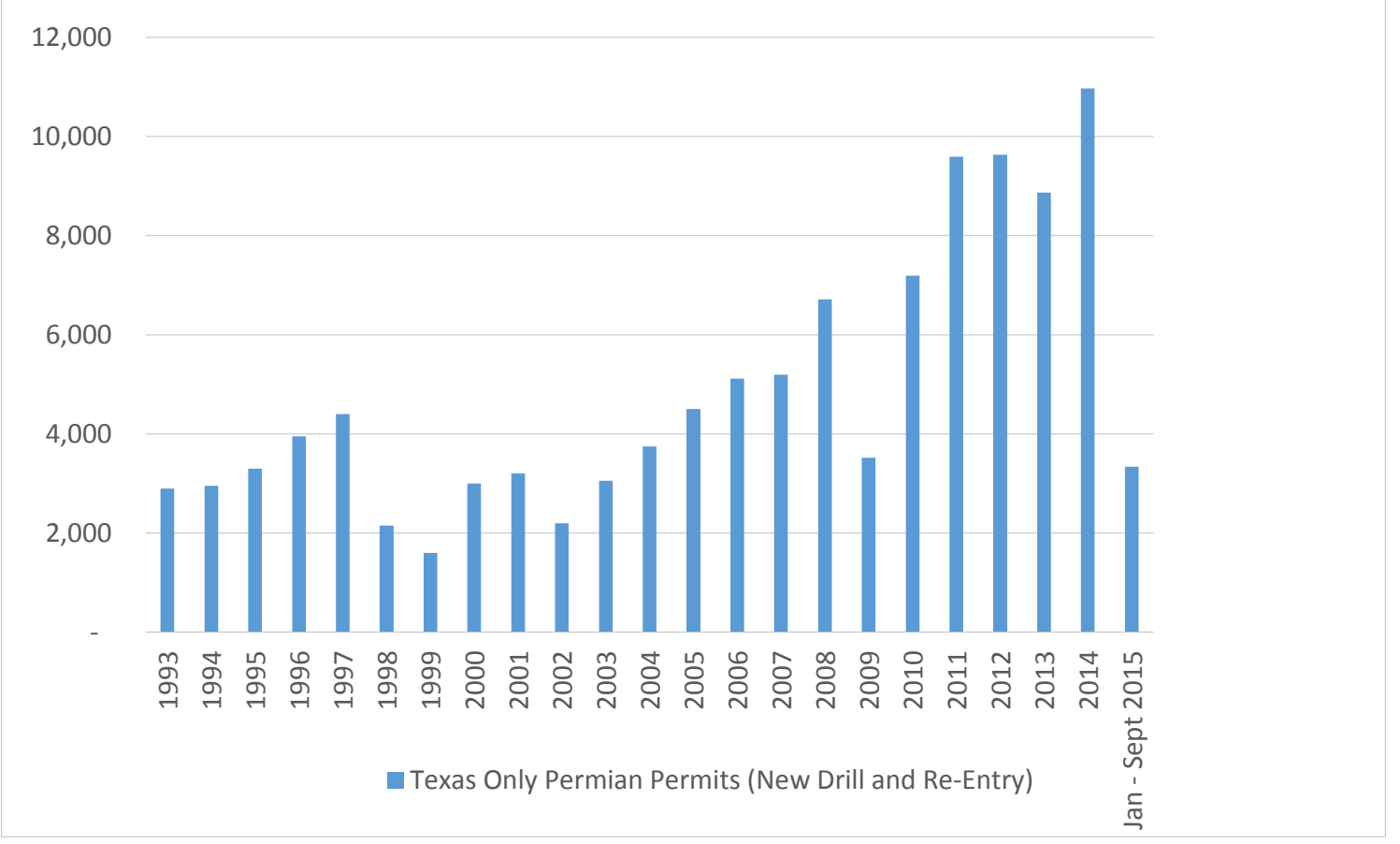

Source: Texas Railroad Commission data

\subsection{Concluding Summary}

The Permian Basin is currently the most resilient oil play in the face of lower oil prices, but this is only relative to its peers - the Bakken and Eagle Ford. Activity levels remain high in comparison, but Texas and New Mexico production is beginning to show the first signs of decline. Many companies in the Permian Basin are still in the early innings of developing their assets, and they have maintained drilling activity levels despite the decline in oil prices because they need to drill in order to hold acreage by production, in addition to adding reserves to the books. However, recent rig additions over the summer have been withdrawn, reflecting multiple months of prices below $\$ 50$ per barrel.

\section{The Eagle Ford Reservoir}

Of the three major shale oil plays, the Eagle Ford is second after the Bakken in terms of unconventional development. After the success realized in the Williston Basin, independent operators were keen to expand their portfolios and new entrants wanted to find the next Bakken. The discovery of the Eagle Ford is largely attributed to one company testing the organic content of a decades worth of old rock samples from a dry well in La Salle County. This testing led them to drill their first well. Together, a handful of companies contributed to the initial development of the Eagle Ford. Initial production results were good and asset prices quickly ascended. New entrants, eager to acquire their first shale assets, paid thousands of dollars per acre as new holes were drilled and production soared.

\subsection{Production Overview}

The Eagle Ford currently produces $1.46 \mathrm{mbd}$ of liquids as of July 2015. Production has risen steadily since 2010, hitting $1.4 \mathrm{mbd}$ in August 2014, rising to over $1.6 \mathrm{mbd}$ in March 2015, and then beginning to decline. Production has receded by $156,000 \mathrm{~b} / \mathrm{d}$ from March to July. Severe flooding and other 

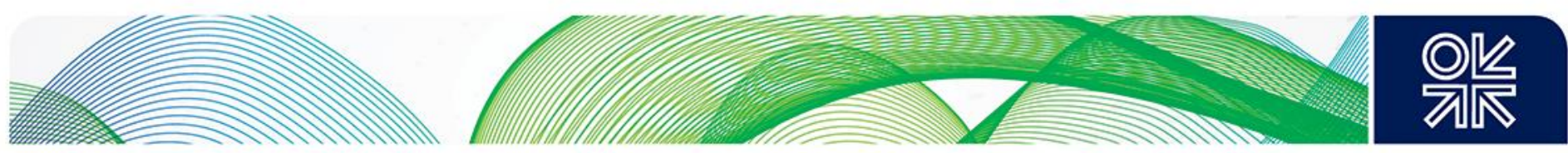

weather constraints have had an impact on Eagle Ford producers in early 2015, but years of pricing discounts due to quality issues may have also reduced producer appetite to grow production. Figure 28 shows a 15-year history of Eagle Ford production, which was almost non-existent until 2009.

\section{Figure 28: Eagle Ford Liquid Production}

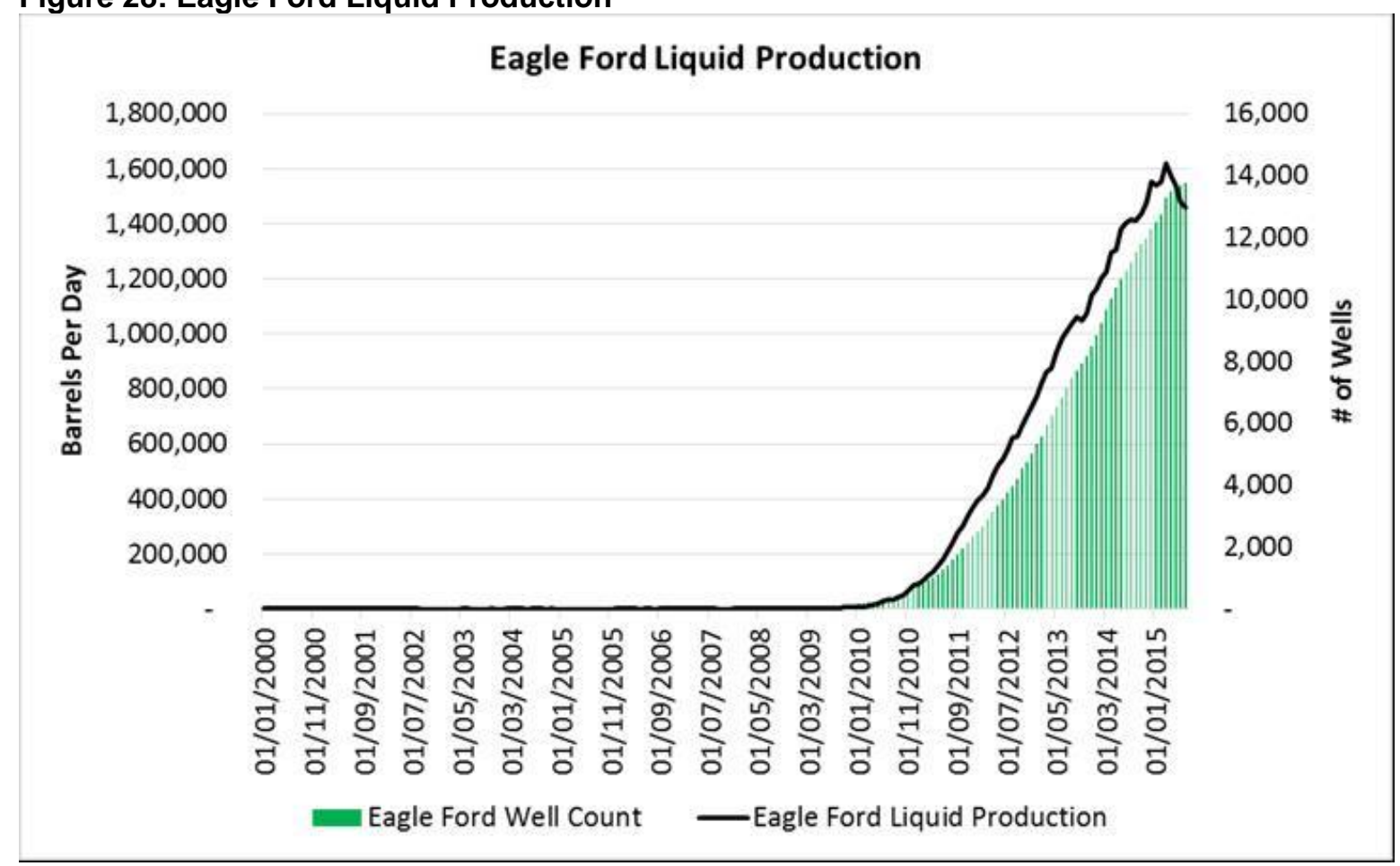

Source: Drillinglnfo data (14 October 2015)

It is estimated that between 40 and 50 per cent of the 1.46 mbd production, roughly $580,000 \mathrm{~b} / \mathrm{d}$ to $730,000 \mathrm{~b} / \mathrm{d}$, is condensate. Condensate was a rarely used term in 2010 . While condensate definitions vary slightly across the oil industry and political sector, it generally refers to oil that is 55 API degrees or above, which means it is extremely light. ${ }^{32}$ The rise in US oil production since 2008 has largely been in the form of light sweet crude oil, but unlike crude oil from the Bakken, which is typically a very stable 43 API degree light sweet crude oil, Eagle Ford crude and condensate tends to vary in API gravity - making it far less consistent for refineries. This is largely a result of the geologic nature of the Eagle Ford reservoir. The play is composed of four producing windows: crude oil, volatile crude oil, condensate and wet gas, and dry gas.

Because condensate is essentially an exceptionally light crude oil, it produces more light ends when refined (such as propane and butane, which are typically blended into gasoline). Many Gulf Coast refineries are configured to process heavy crude oil, such as bitumen from Canada, so they require a bit of tweaking and incentives (discounts) to run higher volumes of a lighter crude oil slate. Figure 29 below shows Eagle Ford crude oil and condensate prices compared to LLS and WTI through September 2015. Since September 2011, the discount between Eagle Ford crude oil 'less than 50 API' and LLS (Light Louisiana Sweet, a major Gulf Coast benchmark for light sweet crude) has varied widely. The average discount in 2015 has been $\$ 9$ per barrel. This is still a considerable discount, but

\footnotetext{
${ }^{32}$ Please see EPRINC's report on condensate for more information. http://eprinc.org/wp-content/uploads/2015/02/EPRINCCondensate-Primer.pdf
} 

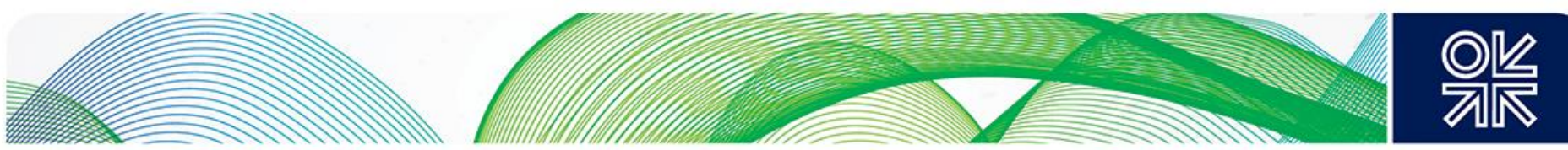

nothing compared to the discounts for condensate 'above 60 API gravity'. The average discount of Eagle Ford condensate 'above 60 API' to LLS has been $\$ 15$ in 2015 (one-quarter of the price of a \$60 barrel of oil). These pricing disparities were the catalysts for the first exports of condensate and the current debate on crude oil exports ${ }^{33}$ (roughly $150,000 \mathrm{~b} / \mathrm{d}$ of condensate are currently being exported, which is far short of expectations). With oil prices consistently above $\$ 80$ for the last few years, these discounts were certainly an issue for producers, but they were not necessarily a grave concern. Discounting becomes more severe as oil prices decline. As prices have slid into the $\$ 40 \mathrm{~s}$, discounts in the Eagle Ford have actually grown. This is partly due to the high volumes of gasoline being produced and stored in the Gulf Coast, reducing the incentive for refineries to run crude oil that will produce a light product slate. Pricing pressure on gasoline has pushed light end blending components lower, thus impacting condensate prices. Quality discounts, especially when combined with existing pricing discounts, further reduce the ability of producers to weather a long-term oil price decline.

Figure 29: Eagle Ford Price Discounts to WTI and LLS (\$/barrel)

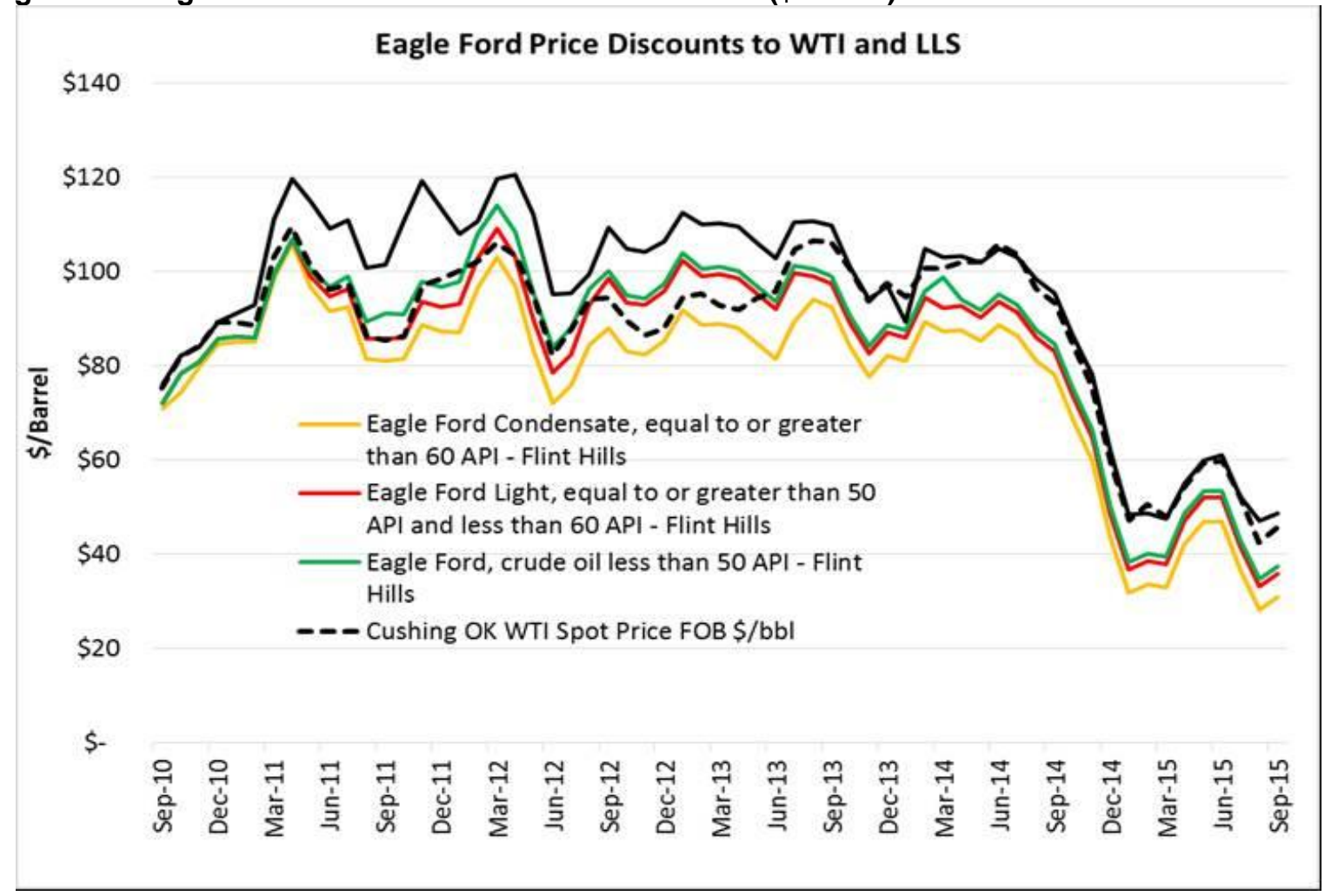

Source: EIA, Flint Hills Resources

\footnotetext{
${ }^{33}$ Condensate can now be exported in the US if it is run through a stabilizer. Because so much activity in the Eagle Ford first took place in the condensate window, a lot of stabilizers already existed in the Eagle Ford. Producers had to 'stabilize' their product in order to strip out the volatile light end components and safely move it by truck or train. Trucks and trains were a major necessity as the Eagle Ford began to boom and pipeline infrastructure did not yet exist. Now, many pipelines safely carry unprocessed condensate to the Gulf Coast where it is either refined locally or put through a stabilizer and then exported abroad. Roughly $150,000 \mathrm{~b} / \mathrm{d}$ of stabilized condensate is currently being exported. This amount is less than many in the petroleum community predicted. For a detailed report about condensate please see EPRINC's paper, as mentioned in the previous footnote.
} 

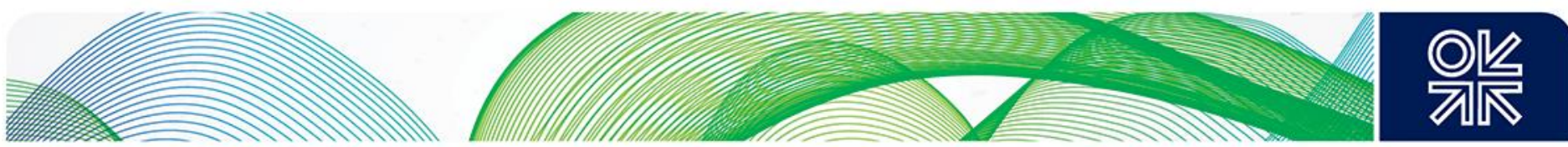

Eagle Ford production has not been as resilient as that of the Permian Basin in the face of lower oil prices. July's 1.46 mbd production figure aligns with April's oil rig count of 110 , which is a decline of 96 from a high of 206 in October 2014 (see Table 4 below). The average monthly oil rig count for September was just 77 , which suggests further production declines to come.

Table 4: Eagle Ford Production and Oil Rig Count

\begin{tabular}{|c|c|c|c|}
\hline $\begin{array}{l}\text { Month - Oil } \\
\text { Production }\end{array}$ & $\begin{array}{l}\text { Eagle Ford Liquid } \\
\text { (includes condensate) } \\
\text { Production b/d }\end{array}$ & Month - Rig & $\begin{array}{l}\text { Eagle Ford Oil } \\
\text { Rig Count }\end{array}$ \\
\hline Jan-14 & $1,164,069$ & Oct-13 & 192 \\
\hline Feb-14 & $1,203,114$ & Nov-13 & 201 \\
\hline Mar-14 & $1,226,651$ & Dec-13 & 203 \\
\hline Apr-14 & $1,296,993$ & Jan-14 & 195 \\
\hline May-14 & $1,304,195$ & Feb-14 & 189 \\
\hline Jun-14 & $1,379,479$ & Mar-14 & 196 \\
\hline Jul-14 & $1,402,986$ & Apr-14 & 210 \\
\hline Aug-14 & $1,416,187$ & May-14 & 208 \\
\hline Sep-14 & $1,409,710$ & Jun-14 & 208 \\
\hline Oct-14 & $1,435,374$ & Jul-14 & 206 \\
\hline Nov-14 & $1,478,188$ & Aug-14 & 196 \\
\hline Dec-14 & $1,553,062$ & Sep-14 & 197 \\
\hline Jan-15 & $1,537,802$ & Oct-14 & 203 \\
\hline Feb-15 & $1,551,803$ & Nov-14 & 196 \\
\hline Mar-15 & $1,616,528$ & Dec-14 & 189 \\
\hline Apr-15 & $1,574,147$ & Jan-15 & 174 \\
\hline May-15 & $1,539,696$ & Feb-15 & 143 \\
\hline Jun-15 & $1,476,168$ & Mar-15 & 126 \\
\hline Jul-15 & $1,460,777$ & Apr-15 & 110 \\
\hline Aug-15 & & May-15 & 87 \\
\hline Sep-15 & & Jun-15 & 84 \\
\hline Oct-15 & & Jul-15 & 80 \\
\hline Nov-15 & & Aug-15 & 81 \\
\hline Dec-15 & & Sep-15 & 77 \\
\hline Jan-16 & & Oct-15 & \\
\hline
\end{tabular}

Source: DrillingInfo production data, Baker Hughes oil rig count

\subsection{Eagle Ford Production and Top Producers}

As with the Bakken, the majority of Eagle Ford production lies in the hands of the top 10 producers, who control over $1 \mathrm{mbd}$ (over 75 per cent) of total production. Over tens of dozens of other companies contribute to the remaining $340,000 \mathrm{~b} / \mathrm{d}$ of liquids production. Many of the top producers already hold most of their acreage by production; therefore, there is little incentive to expand drilling and increase production in the current price environment. More importantly, however, much of this production is in the volatile oil and condensate windows. 

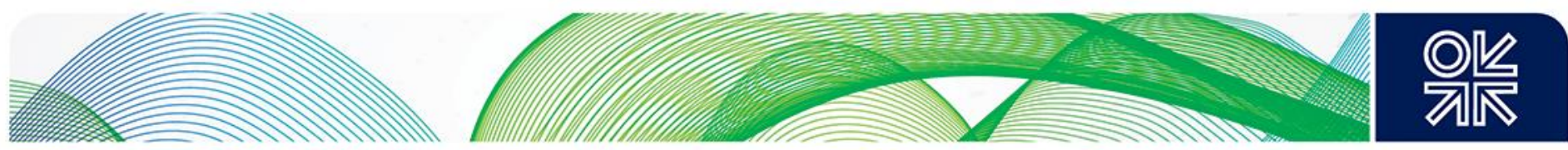

Figure 30: Production Allocation by Top Ten Producers (b/d)

\section{Production Allocation by Top Ten Producers}

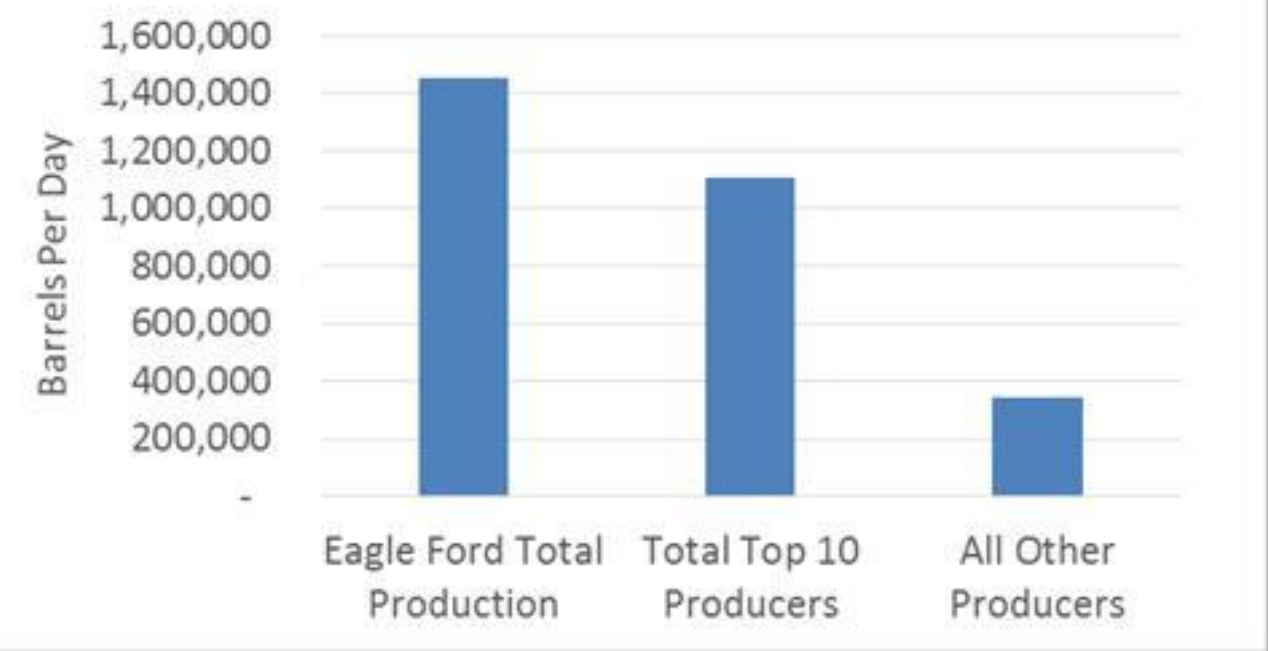

Source: Production data provided by PetroNerds and given to EPRINC (October 2015)

The level of activity by the top producers is noted in the rig breakdown in Figure 31 below. The top companies in the Eagle Ford are running just over half of the operating rigs (42). There are 24 other companies operating 36 rigs. The top producer in Eagle Ford is running just nine rigs and currently produces over $230,000 \mathrm{~b} / \mathrm{d}$, nearly all of which is from the crude oil window. The second-largest producer in the Eagle Ford does not currently have any operating rigs and has not in the last few months. Their assets are largely in the condensate window, but they also have some acreage in the crude oil window. Their production is declining month over month. The third-largest producer ${ }^{34}$ is only operating 3 rigs. The assets of many of the largest Eagle Ford producers are concentrated in the volatile oil, condensate, and natural gas windows, not in the crude oil window. These hydrocarbons are of relatively low value in the current market, disincentivizing production expansions by the top producers.

\footnotetext{
${ }^{34}$ The $3^{\text {rd }}$ and $4^{\text {th }}$ places for top producers is actively changing as producers alter their approaches to lower oil prices.
} 

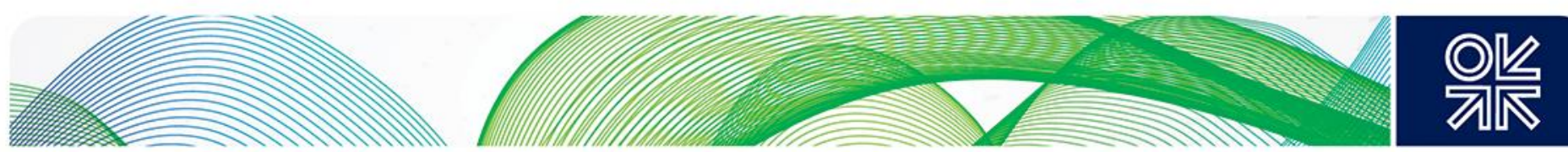

Figure 31: Rig Allocation by Top Producers

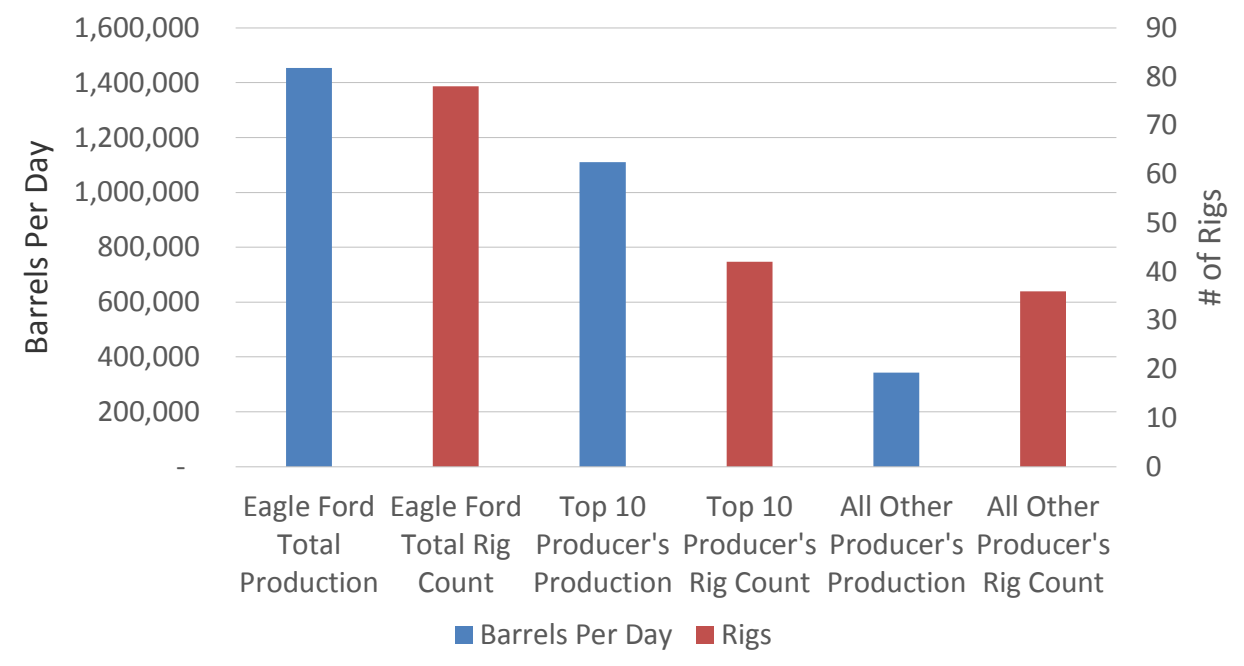

Source: Production data provided by PetroNerds and given to EPRINC (October 2015), DrillingInfo rig data (16 October 2015)

\subsection{Eagle Ford In-Depth}

Several companies in the Eagle Ford are reducing growth forecasts, albeit slightly, for the second half of the year. One company cited weather issues as the reason for the reduction of wells brought online in the second quarter. The same company also saw an area's wells produce below expectations; they are now evaluating the situation. Operators were reducing the number of rigs and frac fleets compared to the first half of the year. Overall, Eagle Ford operators were less clear on their operational plans than operators in the Bakken and Permian Basin, which is a possible indication that some companies are adjusting their area of focus.

Drilling and completion costs declined in the second quarter. Total well costs for some companies were coming in under $\$ 6$ million on average, roughly $\$ 1$ million less than 2014 . Talk of aggressive testing and completion enhancements was not present in many company remarks. However, several companies mentioned testing the upper Eagle Ford (the upper portion of the Eagle Ford reservoir) and were seeing positive or somewhat encouraging results. ${ }^{35}$

Many of the top producing companies in the Eagle Ford have other assets which are drawing their attention and capital away from the Eagle Ford. But for some companies, the Eagle Ford is their core asset and they are continuing to test and delineate existing acreage to further increase reserves and potential well inventory. One top-10 producer has recently acquired its Eagle Ford assets and is working to evaluate and improve well performance. Their approach is to better manage the reservoir pressure in order to increase the overall recovery of liquids from the well. This company is actually restricting initial production in order to properly manage flowing pressure and ensure longer-lasting production through the life of the well.

\footnotetext{
${ }^{35}$ Anadarko Petroleum specifically explained that they were 'actually somewhat encouraged' regarding initial testing of the upper Eagle Ford in their second-quarter earnings/conference call - Seeking Alpha.
} 

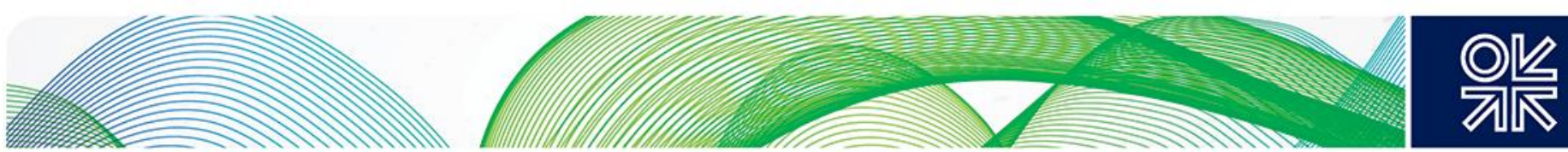

\subsection{Recent Activity and Well Performance}

While a reduction in overall 2015 activity levels is apparent in the Eagle Ford, many wells have still been brought onto production since January 2015 - as shown in Figure 32. Black dots indicate oil or condensate wells and yellow dots indicate dry gas wells.

Figure 32: Well Brought onto Production Since January 2015 in Eagle Ford

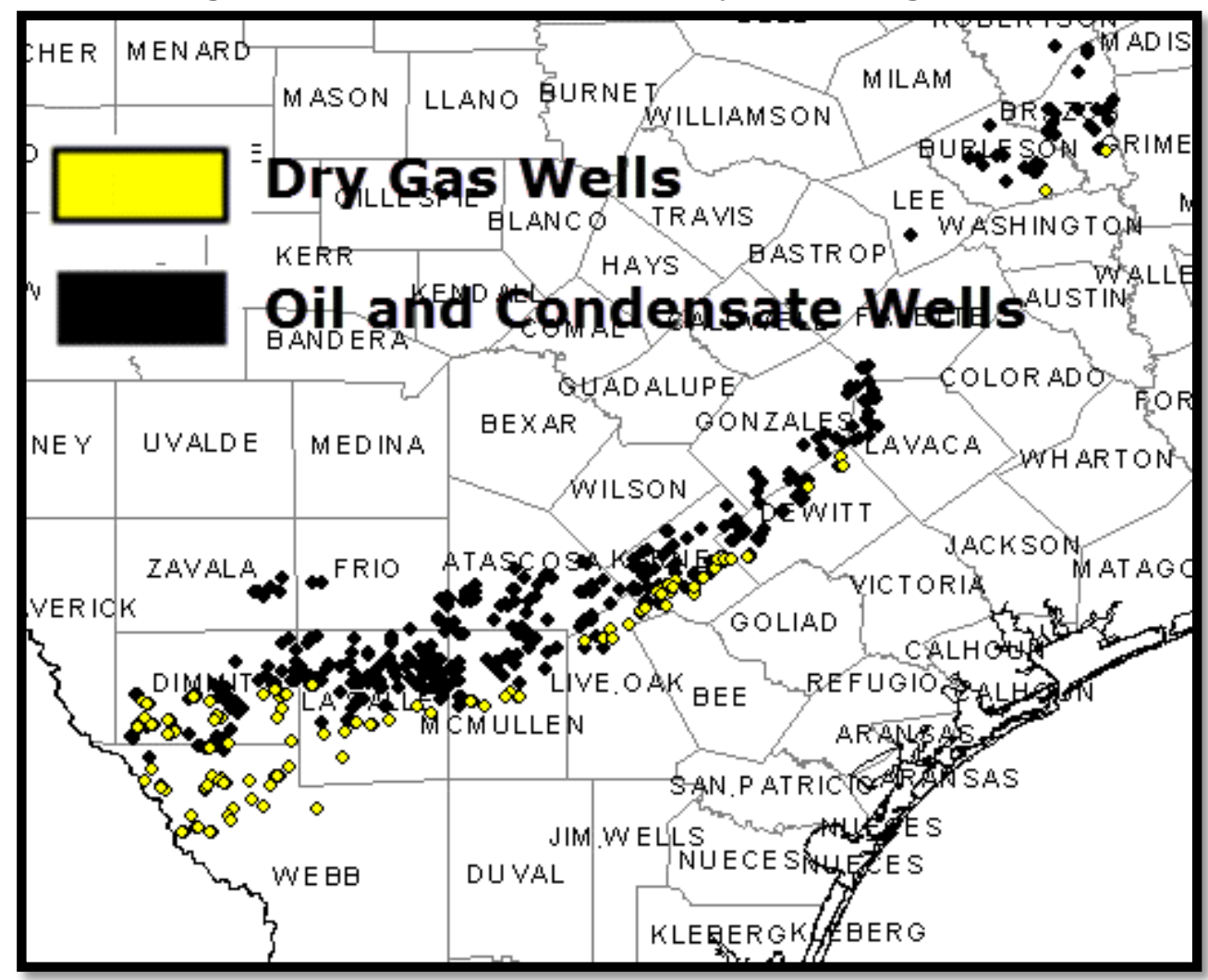

Source: Drillinglnfo, All wells brought onto first production starting 1 January 2015 (15 October 2015)

Well performance has also increased over the course of 2015 but not as much as its peers in the Bakken and Permian Basin. The average initial production rate has risen by $37 \mathrm{~b} / \mathrm{d}$ from 415 in 2014 to 452 in 2015. Eagle Ford average IPs have gradually increased year over year since 2010, as indicated in Figure 33. 

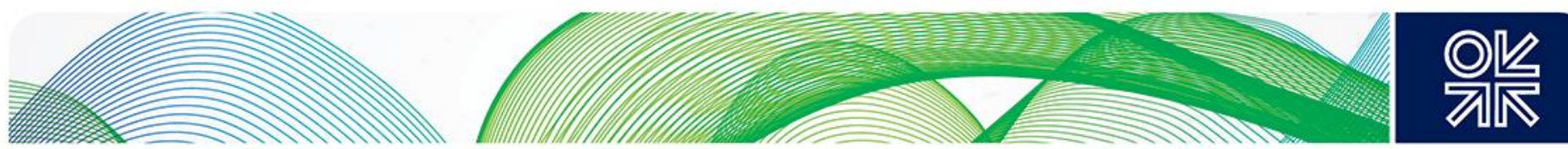

Figure 33: Eagle Ford Initial Production Rates (b/d)

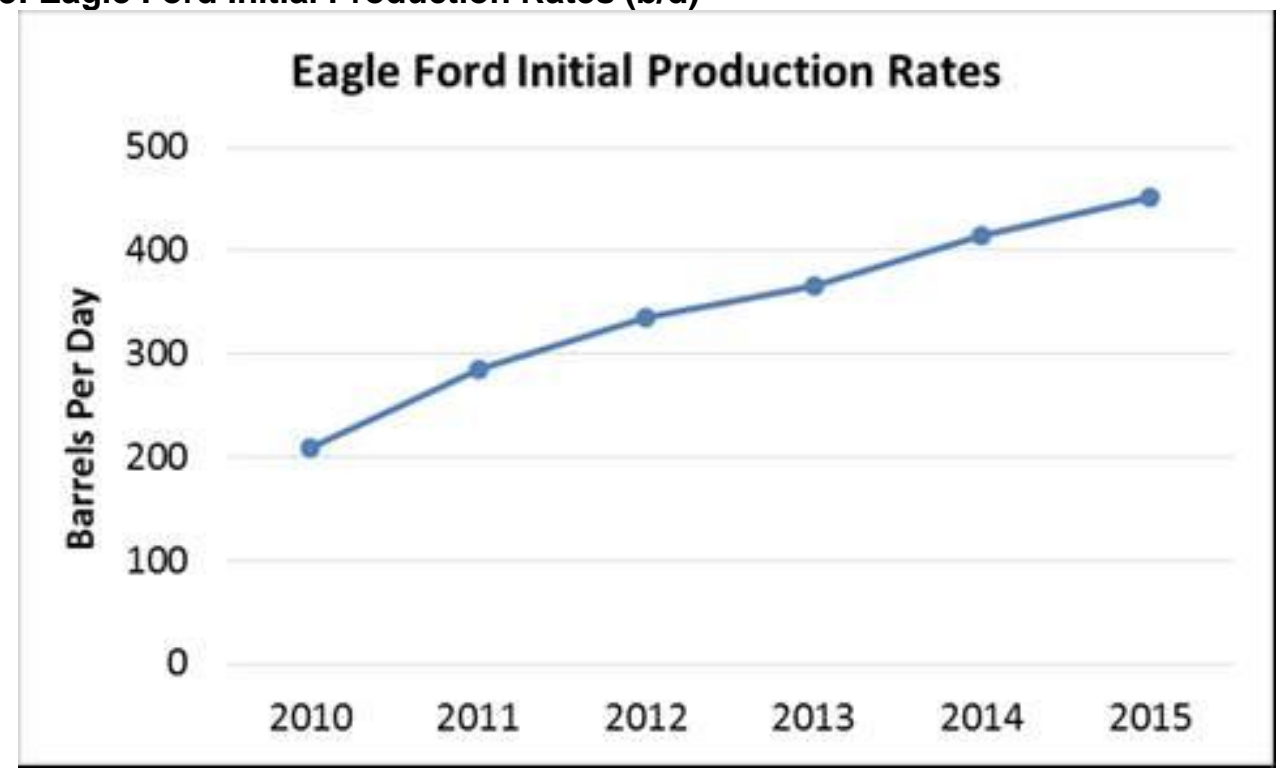

Source: DrillingInfo data and EPRINC estimates (14 October 2015)

The average decline rate or type curve for Eagle Ford wells is roughly the same as 2013, suggesting overall EURs (estimated ultimate recoveries) have not changed greatly over the past three years. The type/decline curve (see Figure 34).

Figure 34: Eagle Ford Production Type/Decline Curves

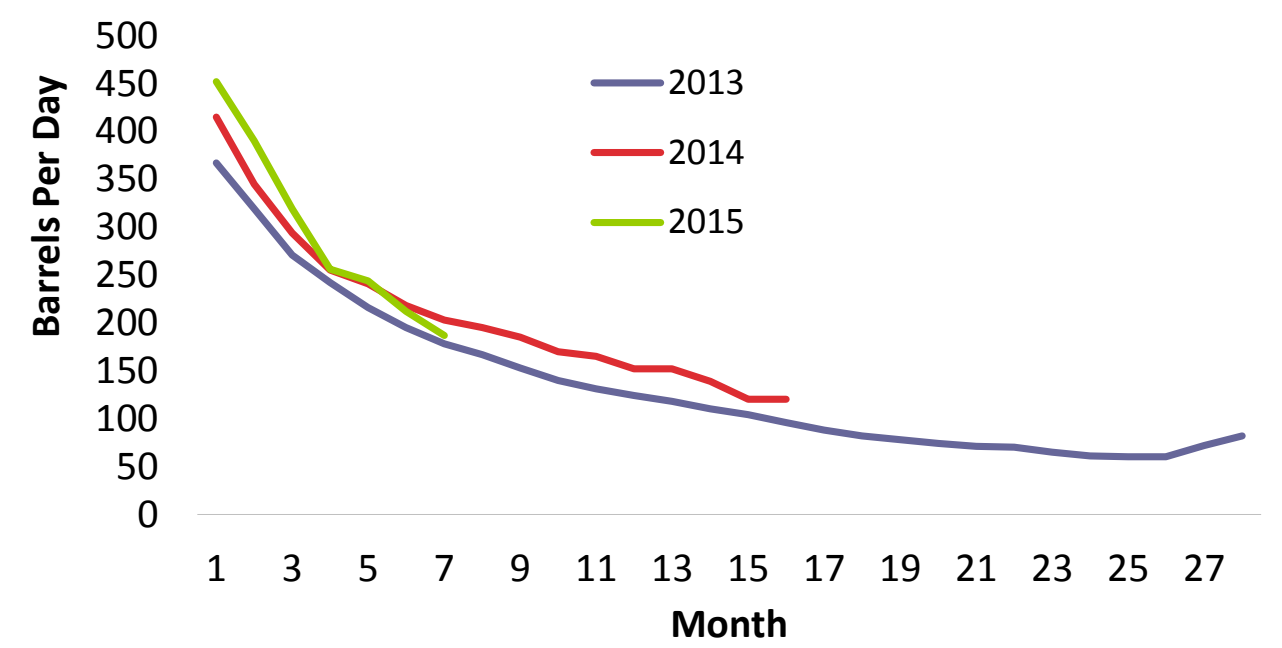

Source: DrillingInfo data and EPRINC estimates (14 October 2015)

Despite increases in IP rates over the past several years, further increases in well performance may be more difficult in the future due to the large volumes of condensate production out of the Eagle Ford. The ability to increase well performance in the condensate window may be limited because condensate acts differently than crude oil in the reservoir and additional pressure management may be needed to maintain steady production levels. 


\subsection{Permits and Rig Count}

The oil rig count in the Eagle Ford has declined dramatically since a recent peak of 206 in October 2014. It is now just 65 , similar to Bakken levels - see Figure 35 below. ${ }^{36}$ While the decline slowed over the summer, it has increased in the last couple of months. Additional rigs will likely be shed before the end of the year as oil prices continue to falter.

Figure 35: Eagle Ford Rig Count by Product

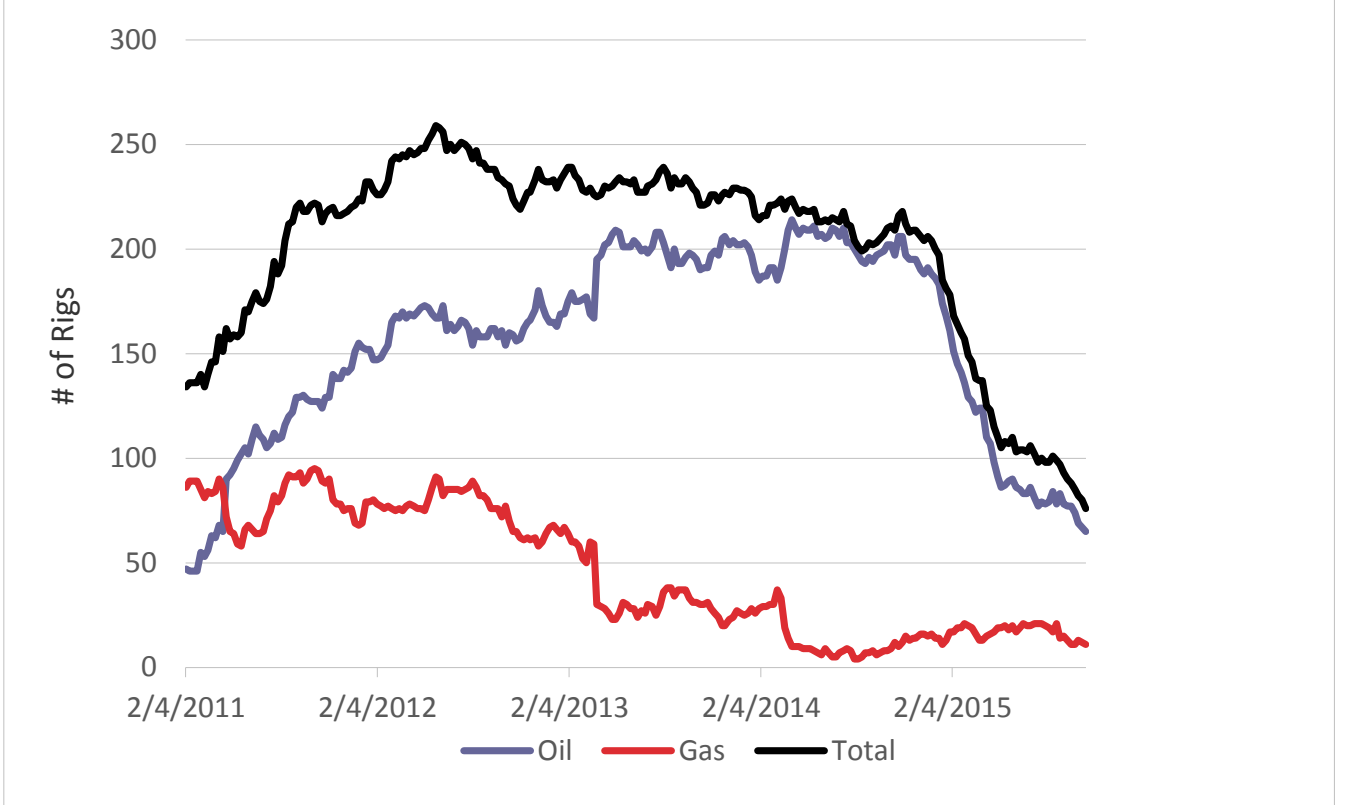

Source: Baker Hughes

Similar to the Bakken and Permian Basin, permit activity levels have regressed substantially, indicating future declines in production growth. As of 16 October 2015, 828 permits had been filed in the past 90 days; 419 lower than the 1,247 in mid-February 2015. ${ }^{37}$ Eagle Ford new drill and re-entry permits totaled 1,879 for the first nine months of 2015. This is down markedly from 2014's total yearly count of 5,613 (see Figure 36). The amount of wells currently waiting on completion is estimated to be around 1,500. ${ }^{38}$ This sharp drop in permitting foreshadows declining production levels in the next several months and early 2016.

\footnotetext{
${ }^{36}$ According to the Baker Hughes 16 October 2015 weekly update, a total of 76 rigs are actively drilling in the Eagle Ford, 65 for oil (and condensate) and 11 for dry gas. Drillinglnfo data shows a total of 78 rigs drilling in the Eagle Ford, 68 drilling for oil and oil and gas, nine for dry gas, and one for injection.

${ }^{37}$ DrillingInfo permit data.

${ }^{38}$ EPRINC estimate.
} 

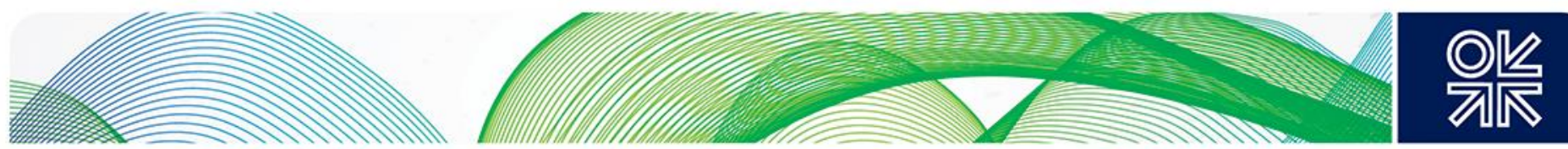

Figure 36: Eagle Ford New Drill and Re-Entry Permits

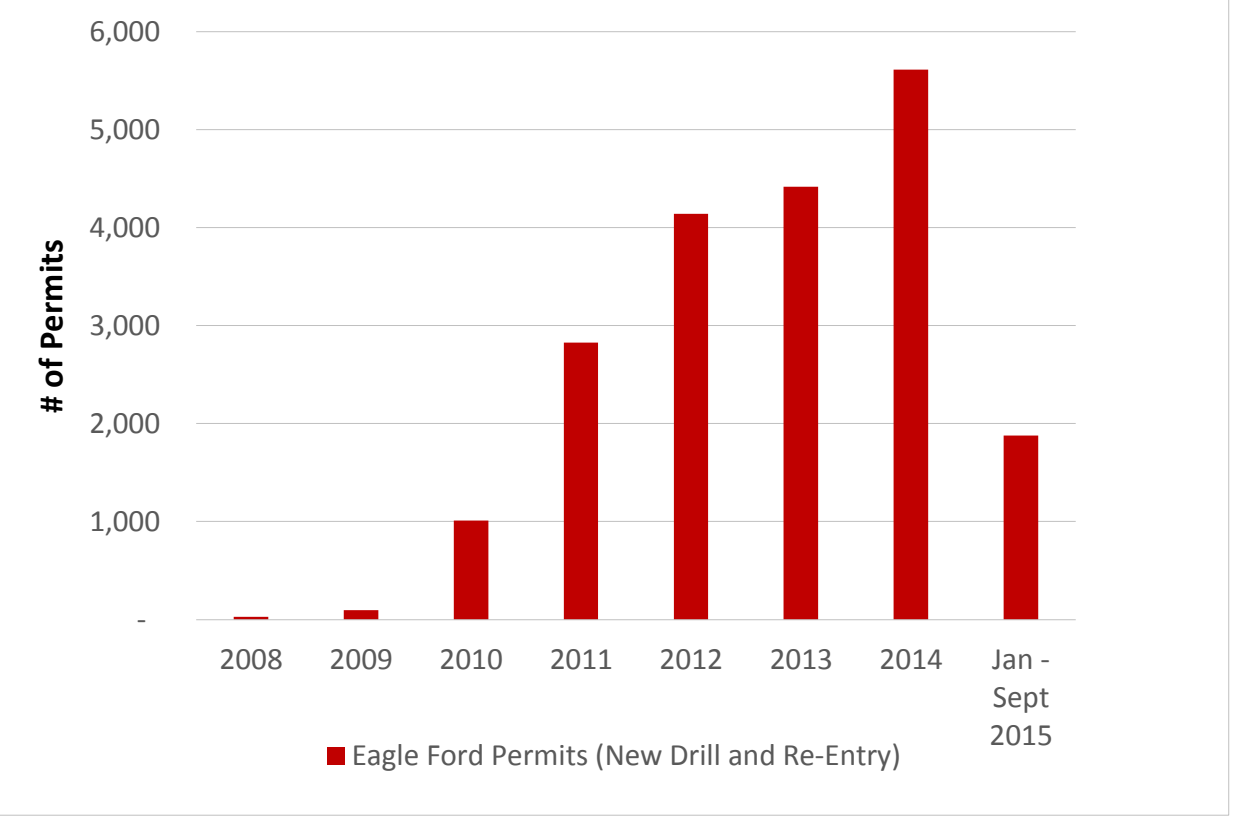

Source: Texas Railroad Commission

\subsection{Concluding Summary}

Of the three major unconventional oil plays, the Eagle Ford has shown the most tangible signs of weakness - production has dropped over 150,000 b/d from March 2015. The top 10 Eagle Ford producers contribute the bulk of Eagle Ford liquids production and many of these operators have concentrated assets in the volatile oil and condensate windows. Production has declined month over month and producer optimism is waning. High crude and condensate discounts already pressured Eagle Ford revenues prior to the price decline and are now further exacerbating the strain on revenues.

\section{Risked Production - Capital Expenditure Cuts and Financial Performance}

The shrinking rig fleet across all major tight oil plays is led by large capital expenditure (CAPEX) cuts to operators' budgets. Oil and condensate production from US tight plays is not going to increase month over month in a price range around $\$ 40$. Activity levels are faltering in the major shale plays, including the Bakken, the Permian Basin, and the Eagle Ford, and it is not only the plays covered in this report that are experiencing slowdowns. Other areas such as the Powder River Basin in Wyoming, the Denver Julesburg Basin in Colorado and Wyoming (commonly known as the Niobrara), and the Anadarko Basin (Oklahoma and Kansas) are facing similar cuts to activity and additional pricing pressure due to high break-even costs and large volumes of associated condensate and NGLs. Numerous oil companies, large and small, have instituted large CAPEX cuts as of the second quarter of 2015. While the industry has managed to do more with less, the combination of these cuts and the loss of hundreds of drilling rigs portends imminent production declines in US tight oil plays. Table 5 below shows 2015 CAPEX cuts (thus far) for a variety of oil companies, many who operate solely in the United States. Thus far, the average 2015 CAPEX cut is 39 per cent compared to 2014. 

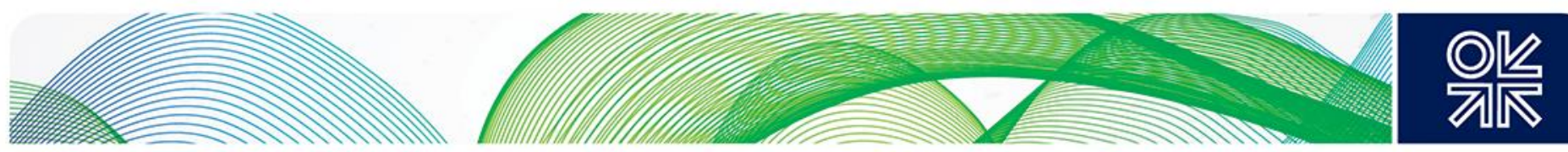

Table 5: Capex Cuts of US Shale Producers

\begin{tabular}{|c|c|c|c|c|c|c|c|c|c|c|c|}
\hline \multirow{2}{*}{$\begin{array}{l}\text { Company } \\
\text { Anadarko }\end{array}$} & \multicolumn{2}{|c|}{$\begin{array}{c}2014 \text { Capex } \\
\text { (millions) }\end{array}$} & \multicolumn{2}{|c|}{$\begin{array}{c}2015 \text { Capex } \\
\text { (millions) }\end{array}$} & \multirow{2}{*}{$\begin{array}{r}\% \text { Change } \\
.40 \%\end{array}$} & \multirow{2}{*}{$\begin{array}{l}\text { Company } \\
\text { Laredo Petroleum }\end{array}$} & \multicolumn{2}{|c|}{$\begin{array}{c}2014 \text { Capex } \\
\text { (millions) }\end{array}$} & \multicolumn{2}{|c|}{$\begin{array}{l}2015 \text { Capex } \\
\text { (millions) }\end{array}$} & \multirow{2}{*}{$\frac{\% \text { Change }}{-58 \%}$} \\
\hline & $\$$ & $9,300.00$ & $\$$ & $5,600.00$ & & & $\$$ & $1,406.00$ & $\$$ & 595.00 & \\
\hline Apache Corp & $\$$ & $9,500.00$ & $\$$ & $3,750.00$ & $-61 \%$ & Laredo Energy & & $\$ 1,000.00$ & & $\$ 595.00$ & $-41 \%$ \\
\hline Bonanza Creek Energy & $\$$ & 667.00 & $\$$ & 420.00 & $-37 \%$ & Linn Energy & & $\$ 1,550.00$ & & $\$ 530.00$ & $-66 \%$ \\
\hline BHP Billiton & $\$$ & $3,700.00$ & $\$$ & $1,500.00$ & $-59 \%$ & Lonestar Resources & & $\$ 140.00$ & & $\$ 76.00$ & $-46 \%$ \\
\hline Breitburn Energy Partners & $\$$ & 375.00 & $\$$ & 200.00 & $-47 \%$ & Magnum Hunter Resources & & $\$ 400.00$ & & $\$ 100.00$ & $-75 \%$ \\
\hline Cabot Oil and Gas & $\$$ & $1,600.00$ & $\$$ & 900.00 & $-44 \%$ & Marathon Oil & & $\$ 5,500.00$ & & $\$ 2,800.00$ & $-49 \%$ \\
\hline Carrizo & $\$$ & 827.59 & $\$$ & 480.00 & $-42 \%$ & MarkWest Energy Partners & & $\$ 2,200.00$ & & $\$ 1,700.00$ & $-23 \%$ \\
\hline Chesapeake Energy & $\$$ & $6,700.00$ & $\$$ & $3,750.00$ & $-44 \%$ & Matador Resources & $\$$ & 614.00 & $\$$ & 425.00 & $-31 \%$ \\
\hline Cimarex Energy & $\$$ & $2,200.00$ & $\$$ & $1,300.00$ & $-41 \%$ & Murphy Oil & & $\$ 3,430.00$ & & $\$ 2,300.00$ & $-33 \%$ \\
\hline Comstock Resources & $\$$ & 587.70 & $\$$ & 248.00 & $-58 \%$ & Newfield Exploration & & $\$ 2,000.00$ & & $\$ 1,400.00$ & $-30 \%$ \\
\hline Concho Resources & $\$$ & $3,000.00$ & $\$$ & $2,000.00$ & $-33 \%$ & Nighthawk Energy & & $\$ 22.40$ & & $\$ 25.00$ & $12 \%$ \\
\hline ConocoPhillips & $\$$ & $16,870.00$ & $\$$ & $11,000.00$ & $-35 \%$ & Noble & & $\$ 4,800.00$ & & $\$ 2,900.00$ & $-40 \%$ \\
\hline CONSOL Energy & $\$$ & $1,000.00$ & $\$$ & 800.00 & $-20 \%$ & NRG Energy & & $\$ 909.00$ & & $\$ 1,700.00$ & $87 \%$ \\
\hline Continental Resources & $\$$ & $5,200.00$ & $\$$ & $2,550.00$ & $-51 \%$ & Oasis Petroleum & & $\$ 1,425.00$ & & $\$ 670.00$ & $-53 \%$ \\
\hline Denbury Resources Inc & $\$$ & $1,100.00$ & $\$$ & 550.00 & $-50 \%$ & Occidental Petroleum & & $\$ 8,700.00$ & & $\$ 5,800.00$ & $-33 \%$ \\
\hline Devon Energy & $\$$ & $5,300.00$ & $\$$ & $4,000.00$ & $-25 \%$ & Parsley Energy & $\$$ & 491.00 & $\$$ & 350.00 & $-29 \%$ \\
\hline Diamondback Energy & $\$$ & 710.00 & $\$$ & 425.00 & $-40 \%$ & PDC Energy & & $\$ 650.00$ & & $\$ 535.00$ & $-18 \%$ \\
\hline Emerald Oil Inc & $\$$ & 225.00 & $\$$ & 72.50 & $-68 \%$ & Penn-Virginia & $\$$ & 686.00 & $\$$ & 335.00 & $-51 \%$ \\
\hline Encana Energy & $\$$ & $2,550.00$ & $\$$ & $2,000.00$ & $-22 \%$ & Pioneer Natural Resources & $\$$ & $3,630.00$ & $\$$ & $2,200.00$ & $-39 \%$ \\
\hline Energen Resources & $\$$ & $1,431.00$ & $\$$ & $1,100.00$ & $-23 \%$ & PostRock Energy & & $\$ 28.00$ & & $\$ 5.50$ & $-80 \%$ \\
\hline Enerplus & $\$$ & 502.00 & $\$$ & 365.00 & $-22 \%$ & QEP Resources & $\$$ & $2,726.00$ & $\$$ & 950.00 & $-65 \%$ \\
\hline EOG Resources & $\$$ & $8,300.00$ & $\$$ & $4,800.00$ & $-23 \%$ & Rosetta Resources & & $\$ 1,200.00$ & & $\$ 750.00$ & $-38 \%$ \\
\hline EP Energy & $\$$ & $2,200.00$ & $\$$ & $1,225.00$ & $-27 \%$ & RSP Permian & $\$$ & 846.00 & $\$$ & 450.00 & $-47 \%$ \\
\hline EQT & $\$$ & $2,700.00$ & $\$$ & $1,800.00$ & $-44 \%$ & Sanchez Energy & & $\$ 870.00$ & & $\$ 575.00$ & $-34 \%$ \\
\hline Exco Resources & $\$$ & 434.80 & $\$$ & 300.00 & $-31 \%$ & SandRidge Energy & & $\$ 1,600.00$ & & $\$ 700.00$ & $-56 \%$ \\
\hline Exxon Mobil & $\$$ & $38,500.00$ & $\$$ & $34,000.00$ & $-12 \%$ & SM Energy & & $\$ 2,100.00$ & & $\$ 1,400.00$ & $-33 \%$ \\
\hline Goodrich Petroleum & $\$$ & 375.00 & $\$$ & 100.00 & $-73 \%$ & Southwestern Energy & & $\$ 2,400.00$ & & $\$ 1,875.00$ & $-22 \%$ \\
\hline Gulfport & $\$$ & $1,100.00$ & $\$$ & 686.00 & $-38 \%$ & Stone Energy & & $\$ 875.00$ & & $\$ 450.00$ & $-49 \%$ \\
\hline Halcon Resources & $\$$ & $1,100.00$ & $\$$ & 400.00 & $-64 \%$ & Swift Energy & & $\$ 400.00$ & & $\$ 115.00$ & $-71 \%$ \\
\hline Hess & $\$$ & $5,600.00$ & $\$$ & $4,400.00$ & $-21 \%$ & Whiting Petroeum & & $\$ 4,000.00$ & & $\$ 2,150.00$ & $-46 \%$ \\
\hline Kinder Morgan & $\$$ & $4,089.00$ & $\$$ & $4,701.00$ & $15 \%$ & WPX Energy & $\$$ & $1,800.00$ & $\$$ & 725.00 & $-60 \%$ \\
\hline
\end{tabular}

Average Capex Cut: $39 \%$

Source: EPRINC data from public sources

An important question to consider is how companies will weather a low oil price environment that looks set to persist into 2016. WTI's late summer plummet is already changing the trajectory of the above outlined CAPEX cuts. The recent rig additions to some plays are already being peeled back. Financial worries are beginning to rise as it becomes more difficult for operator's to generate cash flow. The recent bankruptcy of KKR's Samson Resources helped trigger some of these concerns. Shale development has not been led by cash-rich international oil companies but rather smaller, independent US companies, many of which have struggled to generate positive cash flow even in a $\$ 100$ oil price environment; their profitability, debt burdens, and overall financial stability are issues of concern.

Because much of the oil boom has been initially funded by debt, operators are now faced with further cash flow constraints as they work to pay off old debt (and accumulate new debt, typically at a higher interest rate). Larger amounts of operating cash flow are being spent repaying or servicing debt instead of investing in operating activities such as drilling or purchasing acreage. Figure 37 from the Energy Information Administration (EIA), illustrates the rise in the percentage of debt repayments as a portion of operating cash flow. 

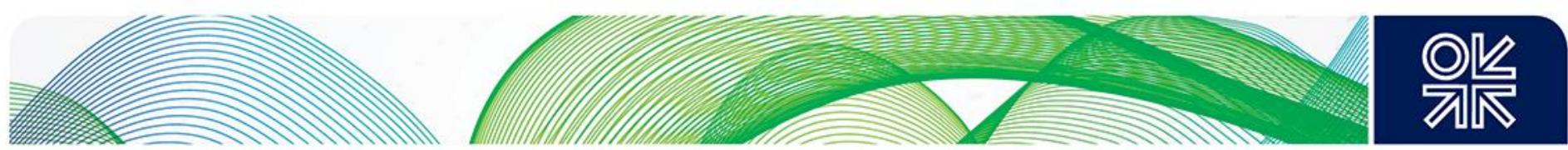

Figure 37: US Onshore Oil Producers' Debt Service as a Share of Operating Cash Flow

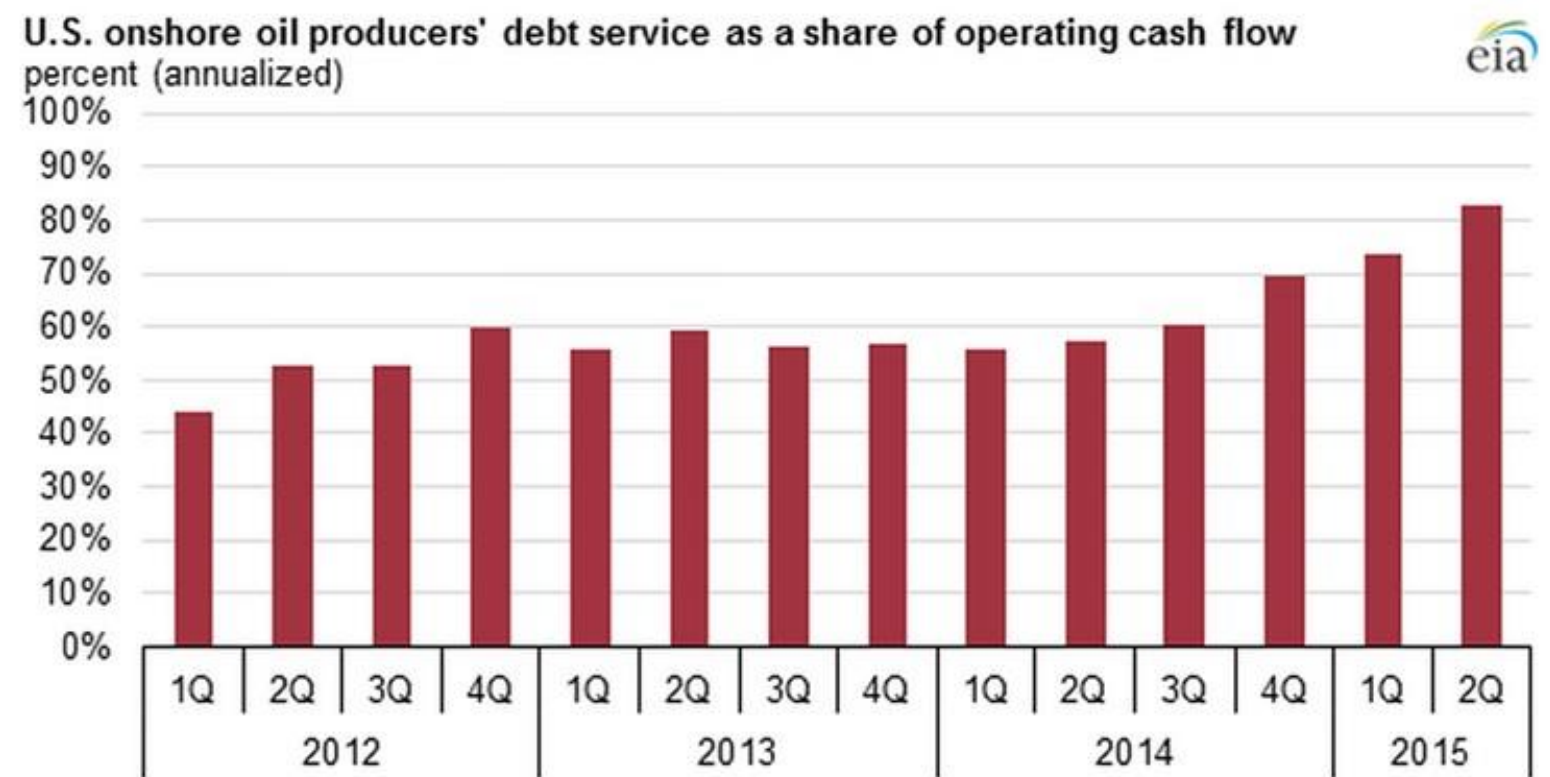

Source: U.S. Energy Information Administration, based on Evaluate Energy Note: Each quarter represents a rolling four-quarter sum.

Source: EIA, Today in Energy, 18 September $2015^{39}$

Since the collapse in oil prices, a handful of companies have filed for bankruptcy. In all likelihood more bankruptcies will occur, but it should be noted that no large independent producers have thus far gone bust. ${ }^{40}$ Most bankruptcies have been limited to companies with 20,000 b/d of oil production or less and a portfolio of assets across crude, condensate, natural gas liquids (NGLs), and dry gas, not overly weighted in oil. In addition to CAPEX cuts, companies are undertaking several measures to ensure survival. Many companies are looking to trim their portfolios and sell fringe assets that are not core acreage positions. Several independent US tight oil operators have already sold their midstream assets for large cash sums, which has helped companies shore up their balance sheets. Operators are also selling natural gas and service related assets. ${ }^{41}$ Others have issued new stock to raise cash or taken on outside investment (debt) to improve their balance sheets. In a low interest rate environment, various funding groups have poured money into investments that are riskier but higheryielding. This has allowed tight oil operators to maintain high debt levels.

These funding groups, such as Blackstone Group LP, Oaktree Capital Group LLC, and Franklin Resources Inc., are beginning to experience some financial pain as oil prices tumble and their sizeable investments in US oil and gas companies book substantial losses on paper. ${ }^{42}$ This has pushed some of these groups to double down or restructure terms ${ }^{43}$ and keep funding many of these oil companies given that their own portfolios would be further in jeopardy should they go bankrupt. Conversely, there are lenders that have reached a point of unwillingness to infuse additional cash into

\footnotetext{
${ }^{39}$ Available at http://www.eia.gov/todayinenergy/detail.cfm?id=22992

40 The top 10 companies in each major tight oil play control 50 to 75 per cent of total play production and have been responsible for a significant amount of oil production growth in the last several years.

${ }^{41}$ Anadarko Petroleum just sold EOR (Enhanced Oil Recovery) properties in the Rockies according to a UBS conference in Houston (17 September 2015, Seeking Alpha).

42 See WSJ article 'Oil and Gas Debt Deals Sting Investors', Matt Jarzemsky and Matt Wirz, 3 August 2015.

${ }^{43}$ Restructuring refers to lenders adjusting the terms of the debt agreement, perhaps giving a company further capital, but at a much higher interest rate, favorable to the lender.
} 

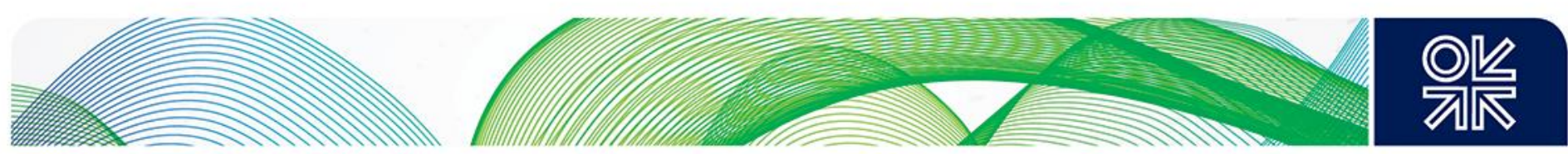

struggling companies and further leverage their portfolios in the oil and gas sector. A small-town bank, for example, may be unwilling to lend additional capital to a company given its already high debt levels and potential insolvency. While this is a risk for some smaller companies with significant debt loads, many of the large-scale producing companies will likely be able to access debt markets and other funding avenues given their sizeable production portfolios and strong oil assets in the three prime oil plays. Investors are looking at the long-term potential of these assets.

Moody's Investor Service released a report at the end of July highlighting credit ratings and liquidity weaknesses for US E\&Ps. ${ }^{44}$ Oil and gas and oil services made up the largest portions of both of Moody's 'low ratings' (PDR of Caa2 or lower) and 'weakest speculative-grade liquidity rating' (SGL-4) heat maps. Of the 43 issuers listed for 'low ratings', 14 were oil and gas and oil service companies. The oil and gas sector comprised 19 of 37 issuers (including upstream, midstream, refining, and services) for Moody's 'weakest speculative-grade liquidity rating'. The report also noted an increased level of US Corporate Family Defaults in the second quarter of 2015, weighted heavily in energy, particular US E\&Ps: seven of the 15 defaults were oil and gas E\&Ps. The types of default for these seven E\&Ps included distressed exchange and missed interest payments.

However, these seven companies in total contribute less than $100,000 \mathrm{~b} / \mathrm{d}$ of crude and condensate production and over 500,000 mcf/day (thousand cubic feet per day) of dry natural gas. Their production portfolios varied greatly and included different assets across the US, but the majority of these seven companies were heavily weighted in gas and liquids production that was not strictly crude oil. Some of them were specifically producing in the Anadarko Basin, where crude production is associated with large cuts of condensate, NGLs, and natural gas. All of these products are further weighing on portfolios in a low oil price environment. These companies had assets stretched across the US and lacked the flexibility to hone in on specific acreage and trim capital expenditures in a low price environment. One hundred thousand barrels a day of liquid production including crude and condensate is nothing to be scoffed at; cumulatively, however, it represents a relatively small risk to overall US production. Should this number be doubled or even tripled to capture a wider net of potentially insolvent companies, it would still be a very small number in comparison to overall US oil production.

\section{Lessons and Predictions}

- US unconventional oil has proved to be more resilient than originally anticipated, and shale producers have been able to maintain production at relatively high levels through several months of low oil prices. Production has only recently begun to decline. Companies are in fact doing more with less: cutting costs and getting higher initial production per well. Drilling and completion costs have come down considerably as the service sector discounts services to try to retain market share. Efficiency gains have proved stronger than anticipated and are a result of a number of factors including better equipment, reduced drilling times, better use of horsepower, and an overall acute awareness of the need to cut costs. This has brought break-even costs to lower than expected levels.

- After 2015's second-quarter conference calls, oil prices dropped to lows of $\$ 37$ dollars a barrel. They have since recovered to the mid- $\$ 40$ range (at the time of writing), but this movement paints a bleak picture for future production. A further reduction in CAPEX, shrinking oil rig counts, reduced risk appetite among lenders, and the potential for rising interest rates are all weighing on future production levels in the US.

\footnotetext{
${ }^{44}$ Moody's Investor Service, 30 July 2015, Sector In-Depth report.
} 

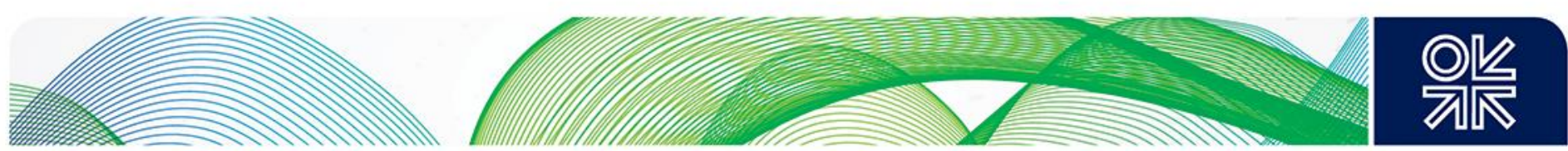

- Despite efficiency gains, the number of rigs drilling for oil continue to decline as oil prices falter. This depressed rig count is just now beginning to impact production levels and will further impact production in the coming months. The Bakken has been able to maintain production around $1.2 \mathrm{mbd}$, but this is expected to decline considerably in the coming months. Large producers have continued to drill and see success in core acreage positions, but little activity is taking place outside of the core. Permian Basin production levels are beginning to recede, but they remain around $1.9 \mathrm{mbd}$. Drilling activity and asset delineation remains robust in comparison to the Bakken and Eagle Ford. Greater producer diversification exists in the Permian Basin as well. Some of these producers are still delineating assets and working to hold acreage by production. Eagle Ford liquids production has already declined by nearly $160,000 \mathrm{~b} / \mathrm{d}$ to $1.46 \mathrm{mbd}$ (since March 2015). Producers have so far been very vague about their activity plans in this play. Similar to the Bakken, the Eagle Ford lacks producer diversification. Many of the top 10 producers hold acreage in the volatile oil and condensate window. These assets produce discounted oil and condensate, thus further reducing producer incentive to drill in an already low oil price environment. Given the current rig count, lag time between drilling activity and production, and the rising number of wells that are drilled but waiting on completion, US oil production could easily fall by more than $1 \mathrm{mbd}$ early next year from April's 9.6 mbd peak (assuming a 125,000 b/d month over month decline).

- Companies are spending more efficiently and wisely, but profitability was tough to come by at $\$ 100$ oil and companies were aggregately adding billions of dollars of debt each quarter. The stronger and larger independent companies should be able to survive a long-term lull intact, but acquisitions can be expected given depressed equity values. In addition to oil price risk, rising interest rates and a reduction in risk appetite among lenders pose survivability risks for some operators, particularly for companies who plan to borrow to survive until oil prices recover. Debt restructuring and lending will continue to take place, but this will not result in increased production levels. Further consolidation in the US shale sector could enhance the long-term resilience of the sector.

- How long oil prices remain low is a key determinant in the flexibility of US crude production. The US will not be a swing producer in the conventional OPEC sense where production can quickly be turned on and off within months. Relatively resilient oil production in the face of $\$ 40$ prices is already indicative of this. Should oil prices remain depressed through the duration of 2016, it will take additional time to raise production levels. Many people have already lost their jobs and much deeper cuts remain a reality. Service providers will go out of business. While the US is a flexible and liquid market, it will take time to bring the workforce back when oil prices rise.

- Low oil prices will not kill the US shale industry, but they may put it into hibernation. Further rock analysis and technological advances need to be made in order to move the industry forward and reduce costs. Severe CAPEX cuts will reduce these advances in the near term. 